\title{
Description and Validation of an Automated Methodology for Mapping Mineralogy, Vegetation, and Hydrothermal Alteration Type from ASTER Satellite Imagery with Examples from the San Juan Mountains, Colorado
}

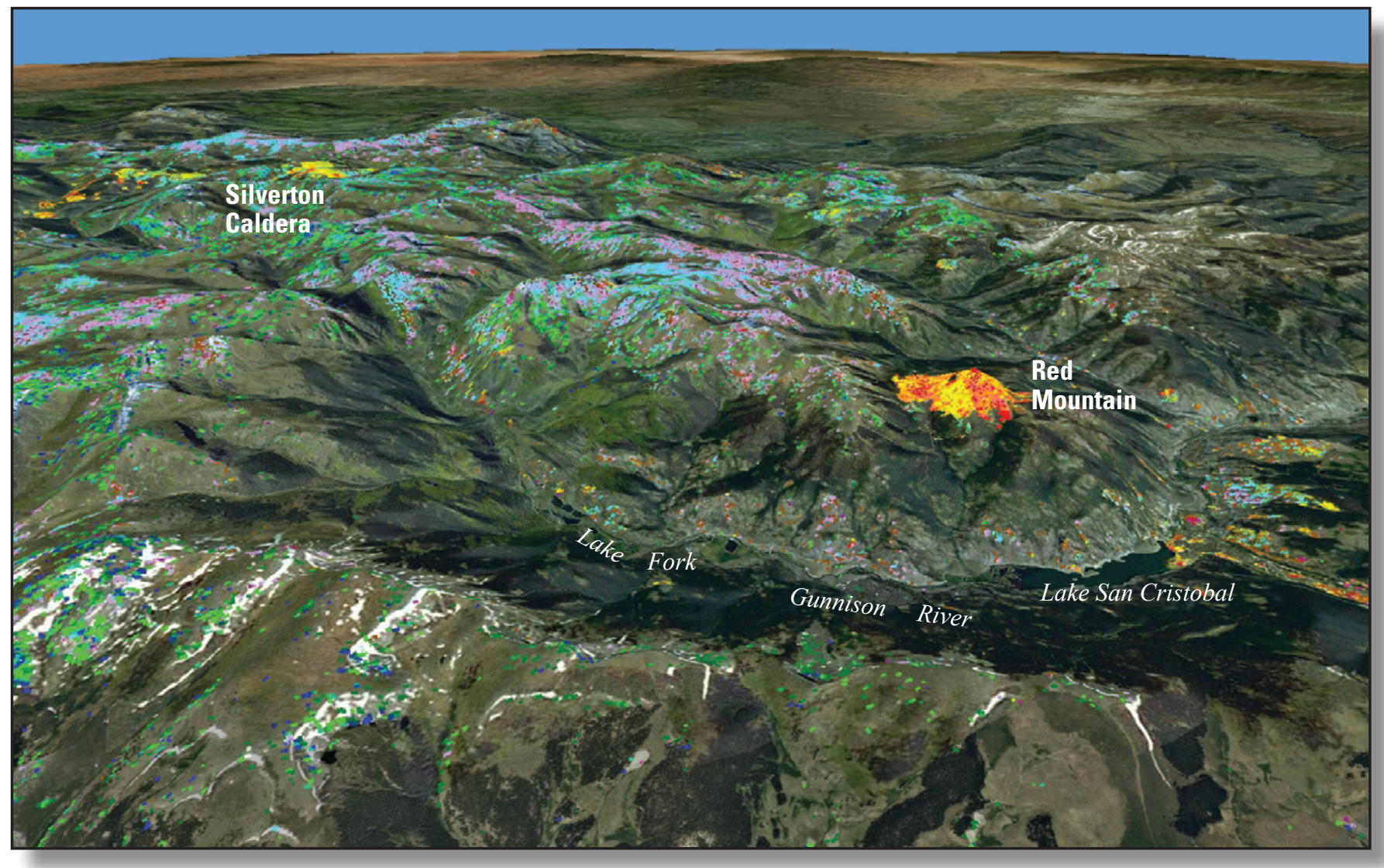

Scientific Investigations Map 3190 
Cover: Three-dimensional perspective view of the Lake City caldera in the San Juan Mountains of Colorado, looking toward the northwest. A map showing surficial occurrence of clay, sulfate, mica, carbonate, and other minerals derived from spectroscopic analysis of ASTER data provided in this publication is draped over a USGS digital elevation model. Background image is derived from National Agriculture Imagery Program aerial photography. Lake San Cristobal along the Lake Fork of the Gunnison River is visible at right. Advanced argillic alteration (shown in yellow, red, and orange colors) is clearly visible on Red Mountain above the lake and within the Silverton caldera in the distance at upper left. 


\section{Description and Validation of an Automated Methodology for Mapping Mineralogy, Vegetation, and Hydrothermal Alteration Type from ASTER Satellite Imagery with Examples from the San Juan Mountains, Colorado}

By Barnaby W. Rockwell 


\section{U.S. Department of the Interior \\ KEN SALAZAR, Secretary \\ U.S. Geological Survey \\ Marcia K. McNutt, Director}

U.S. Geological Survey, Reston, Virginia: 2012

For product and ordering information:

World Wide Web: http://www.usgs.gov/pubprod

Telephone: 1-888-ASK-USGS

For more information on the USGS - the Federal source for science about the Earth,

its natural and living resources, natural hazards, and the environment:

World Wide Web: http://www.usgs.gov

Telephone: 1-888-ASK-USGS

Any use of trade, product, or firm names is for descriptive purposes only and does not imply endorsement by the U.S. Government.

Although this report is in the public domain, permission must be secured from the individual copyright owners to reproduce any copyrighted materials contained within this report.

Suggested citation:

Rockwell, B.W., 2012, Description and validation of an automated methodology for mapping mineralogy, vegetation, and hydrothermal alteration type from ASTER satellite imagery with examples from the San Juan Mountains,

Colorado: U.S. Geological Survey Scientific Investigations Map 3190, 35 p. pamphlet, 5 map sheets, scale 1:100,000. 


\section{Contents}

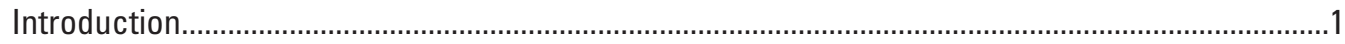

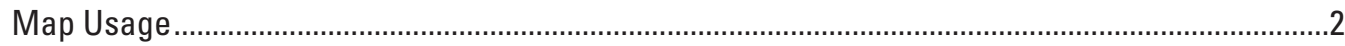

Descriptions of Map Sheets and Associated ERDAS Imagine Raster Image Files ..........................2

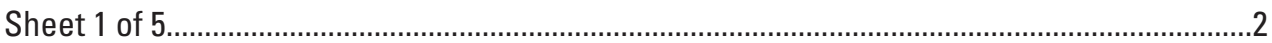

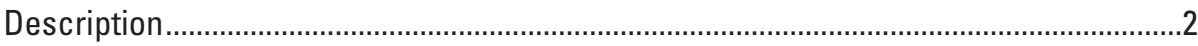

Purpose

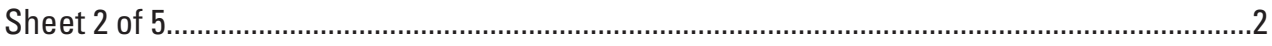

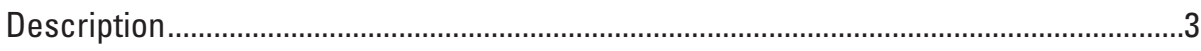

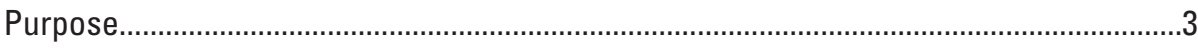

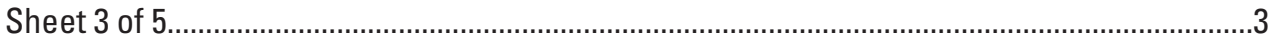

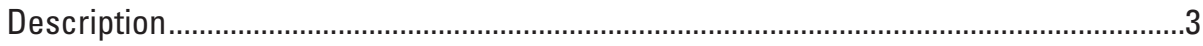

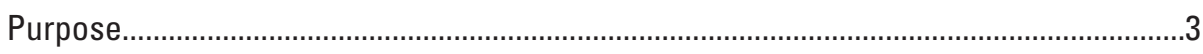

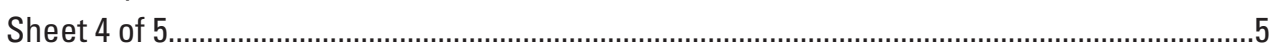

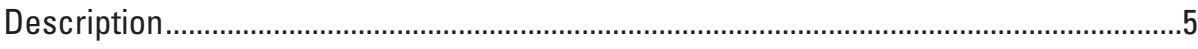

Purpose

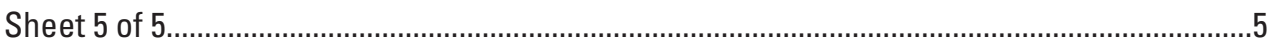

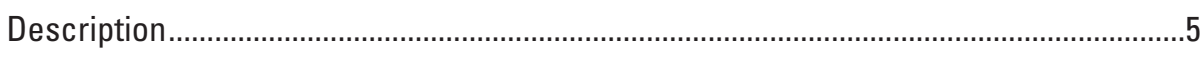

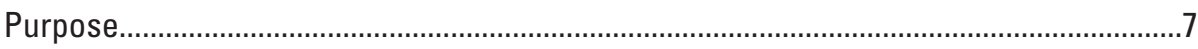

Description of Automated Analysis Methodology ……................................................................

Mineral Group and Green Vegetation Indices .......................................................................

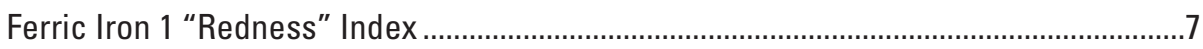

Ferric Iron Index 2

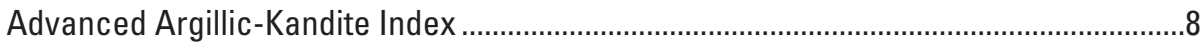

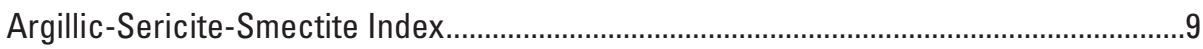

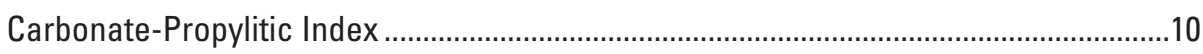

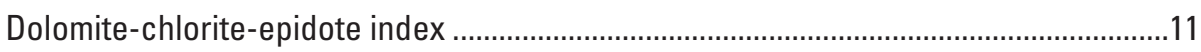

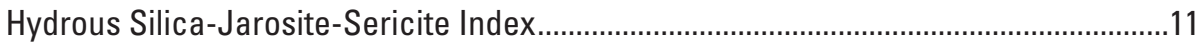

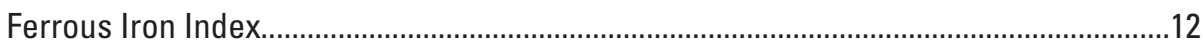

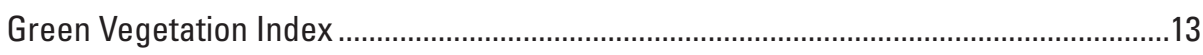

Image Processing for Masking and Index Thresholding ...................................................14

Dark Area Masking ...................................................................................................

Water Masking ........................................................................................................

Selective Vegetation Suppression.......................................................................... 14

Final Index Thresholding and Clipping .....................................................................14

Modeling of Hydrothermal Alteration Type and Mineral Groups through Boolean Combination of Index Results............................................................................16

Comparison and Validation of Automated Results .....................................................................19

Silverton Caldera, San Juan Mountains, Colorado ............................................................19

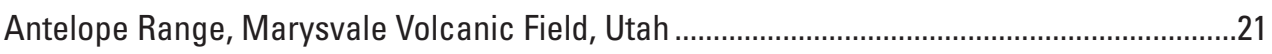

Goldfield Mining District, Nevada ...................................................................................2

Cuprite Mining District, Nevada .....................................................................................24

Pine Grove and Blawn Mountain Mining Districts, Wah Wah Mountains, Utah ....................29

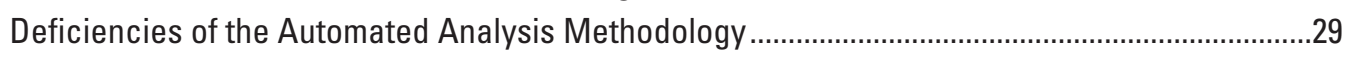

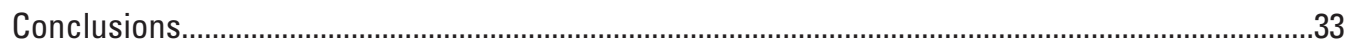




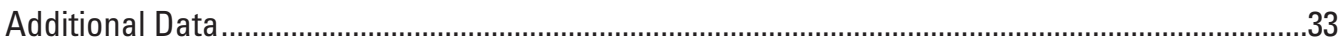

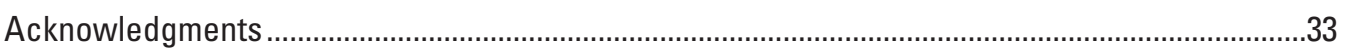

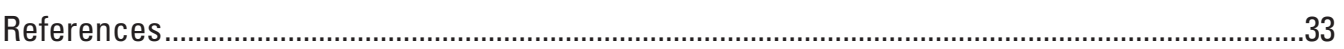

\section{Figures}

1. Plots of laboratory reference spectra convolved to ASTER spectral resolution and ASTER pixel spectra of muscovites and a muscovite + chlorite mixture..

2. Plots of laboratory reference spectra convolved to ASTER spectral resolution...............8

3. Plots of laboratory reference spectra of alunite, pyrophyllite, and kaolinite convolved to ASTER spectral resolution

4. Plots of laboratory reference spectra of sericite, smectite, and kaolinite convolved to ASTER spectral resolution.

5. Plots of laboratory reference spectra of calcite, dolomite, chlorite, and epidote convolved to ASTER spectral resolution.

6. Plots of laboratory reference spectra of ferrous iron-bearing minerals convolved to ASTER spectral resolution.

7. Comparison of ferrous iron-bearing minerals identified in the Silverton, Colorado, area using AVIRIS data and the automated ferrous iron index.

8. Comparison of mineral maps of the area between the Goldfield and Cuprite mining districts, western Nevada, produced from AVIRIS and ASTER data

9. Comparison of occurrencesof jarosite + sericite detected in the Silverton, Colorado, caldera

10. Comparison of advanced argillic, argillic, and phyllic alteration in the Silverton, Colorado, caldera

11. Mineral maps of the Antelope Range area of the Marysvale volcanic field, Utah using $A$. ASTER data and $B$. automated ASTER data.

12. Mineral maps of the Goldfield mining district, Nevada. $A$, Map produced using expert system-based spectroscopic analysis. $B$, Map produced using expert system-based spectroscopic analysis and $C$, Map produced from orthocorrected (AST140TH) data of the same 2001 ASTER scene

13. Mineral maps of the Montezuma mining district, Nevada

14. Mineral maps of part of the Cuprite mining district in western Nevada produced using expert system-analysis of 1998 high-altitude AVIRIS data. A. Map showing occurance of iron-bearing minerals, and $B$. Map showing occurance of clay, sulfate, mica, carbonate, $\mathrm{Mg}-\mathrm{OH}$ and hydrous silica minerals.

15. ASTER-derived mineral maps of part of the Cuprite mining district, western Nevada

16. ASTER-derived mineral maps of the Wah Wah Mountains, Broken Ridge, and Escalante Desert, southwestern Utah

17. Explanations for color-coded mineral and vegetation identifications.

$A$, Identifications for map in figure $16 A$. $B$, Identifications for map in figure $16 B$ 


\section{Tables}

1. Boolean logic used to combine results of separate iron mineral, vegetation, and water analysis. 6

2. Boolean logic used to combine index results into a single, classified map... . .17

\section{Maps}

Maps of mineralogy, vegetation, and hydrothermal alteration type generated from ASTER satellite data-San Juan Mountains, Colorado

1. Continuous-tone map of mineral groups ................................................................. link

2. Map of Iron-bearing minerals, vegetation, and water ............................................... link

3. Map of clay, sulfate, mica, carbonate, $\mathrm{Mg}-\mathrm{OH}$, and hydrous silica minerals .............. link

4. Map of modeled hydrothermal alteration type ........................................................ link

5. Map of modeled hydrothermal alteration type, mineral groups, and green vegetation generated by automated analysis.

\section{Conversion Factors}

SI to Inch/Pound

\begin{tabular}{lll}
\hline \multicolumn{1}{c}{ Multiply } & By & \multicolumn{1}{c}{ To obtain } \\
\hline kilometer $(\mathrm{km})$ & Length & \\
meter $(\mathrm{m})$ & 0.6214 & mile $(\mathrm{mi})$ \\
$\operatorname{micron}(\mu \mathrm{m})$ & 3.281 & foot $(\mathrm{ft})$ \\
\hline
\end{tabular}

Horizontal coordinate information is referenced to the World Geodetic System 1984 (WGS 84). 


\title{
Description and Validation of an Automated Methodology for Mapping Mineralogy, Vegetation, and Hydrothermal Alteration Type from ASTER Satellite Imagery with Examples from the San Juan Mountains, Colorado
}

\author{
By Barnaby W. Rockwell
}

\section{Introduction}

The efficacy of airborne spectroscopic "hyperspectral" remote sensing for geoenvironmental watershed evaluations has been demonstrated (Dalton and others, 2004; 2007, Rockwell and others, 2005). However, the acquisition, processing, and analysis of such airborne data at regional and national scales can be time and cost prohibitive. The Advanced Spaceborne Thermal Emission and Reflection Radiometer (ASTER, http://asterweb.jpl.nasa.gov/) sensor carried by the NASA Earth Observing System Terra satellite was designed for mineral mapping and the acquired data can be efficiently used to generate uniform mineral maps over very large areas.

Multispectral remote sensing data acquired by the ASTER sensor were analyzed to identify and map minerals, mineral groups, hydrothermal alteration types, and vegetation groups in the western San Juan Mountains, Colorado. This mapping was performed in support of multidisciplinary studies involving the predictive modeling of surface-water geochemistry at watershed and regional scales. These studies seek to determine the relative effects of mining and non-anthropogenic hydrothermal alteration on surface water geochemistry and faunal populations.

Detailed maps of minerals, vegetation groups, and water (sheets 2 and 3 ) were produced from an ASTER scene using spectroscopic expert system-based analysis techniques described by Rockwell (2009) and references therein. This publication also presents new methodologies for the modeling of hydrothermal alteration type based on the Boolean combination of the detailed mineral maps, and for the automated mapping of alteration types, mineral groups, and green vegetation. Results of these methodologies are provided (sheets 4 and 5) for comparison with the more detailed maps in sheets 2 and 3 and with previously published mineral mapping results derived from analysis of high-resolution spectroscopic data acquired by the Airborne Visible/Infrared Imaging Spectrometer (AVIRIS, http://aviris.jpl.nasa.gov/) sensor (Dalton and others, 2004; 2007). Additional comparisons of these maps are provided by Rockwell (2010b). The automated mineral group mapping products described in this study are ideal for application to mineral resource and mineral-environmental assessments at regional and national scales.

Unlike other ASTER data analysis methodologies designed for large-area mineral mapping (Mars and Rowan, 2006), the automated methodologies presented herein exploit the full dimensionality of the nine spectral bands of ASTER data that measure reflective electromagnetic energy (0.4-2.5 $\mu \mathrm{m}$ (microns)). The mapping of iron minerals from the visible and near-infrared data offers a means of inferring the occurrence of pyritic rocks with high net acid production (NAP) and of mapping iron-bearing lithologic units. High concentrations of jarosite derived from pyrite oxidation that are unobscured by argillic weathering products are also identified. Occurrences of hydrous quartz (for example, opal and chalcedony) typically of volcano-hydrothermal origin are identified. The identification of acid-neutralizing carbonate rocks and propylitic alteration is also vital for estimating surface water $\mathrm{pH}$.

Digital mineral and vegetation mapping results are presented in both portable document format (PDF) and ERDAS Imagine format (.img). The ERDAS-format files are suitable for integration with other geospatial data in Geographic Information Systems (GIS). The ERDAS files showing occurrence of (1) iron-bearing minerals, vegetation, and water (sheet 2);

(2) clay, sulfate, mica, carbonate, $\mathrm{Mg}-\mathrm{OH}$, and hydrous quartz minerals (sheet 3), and (3) modeled hydrothermal alteration type (sheet 4), and (4) mineral and vegetation groups identified using automated analysis (sheet 5) have been attributed according to identified material, so that the material detected in a pixel can be queried with the interactive attribute identification tools of GIS and image processing software packages (for example, the Identify Tool of ArcMap and the Inquire Cursor Tool of ERDAS Imagine).

All raster data have been orthorectified to the Universal Transverse Mercator (UTM) projection using a projective transform with ground-control points selected from Terra Server digital orthophoto quadrangles, digital raster graphics, and a digital elevation model from the U.S. Geological Survey (USGS) National Elevation Dataset (NED, 
http://ned.usgs.gov/, 1/3 arc second, 10-m resolution). Positional errors are commonly less than $60 \mathrm{~m}$, but may be locally greater in areas of high terrain relief outside of the Silverton caldera where fewer geometric control points were collected.

Metadata compliant with Federal Geographic Data Committee (FGDC) standards have been included for all ERDAS-format files, and contain important information regarding geographic coordinate systems, attributes, and cross-references.

\section{Map Usage}

The image maps were designed primarily for the regional mapping and characterization of exposed surface mineralogy, including that related to hydrothermal alteration. As hydrolytic alteration commonly occurs along faults and fractures that serve as conduits for potentially metal-bearing fluids, the presence and type of alteration can provide important information for mineral resource investigations. Pyrite is a common gangue mineral associated with hydrothermal alteration and many types of ore deposits, and produces sulfuric acid upon subaerial exposure which can leach and transport potentially toxic metals into the ground water system. Knowledge of pyrite occurrences and the extent and type of alteration is vital in developing predictive models of downstream surface water geochemistry in both mined and unmined catchments and to evaluate pre- and post-mining effects of altered areas on local hydrology.

The maps generated by spectroscopic analysis techniques present the most detailed and accurate ASTER-derived information on the spatial occurrence of minerals and mineral assemblages. The maps of alteration types and key mineral groups modeled from the detailed maps are well-suited for use in quantitative, GIS-based modeling for geoenvironmental watershed studies in that the values of relative acid producing and neutralizing potential can be readily assigned to the data elements. The less-detailed map generated using automated analysis techniques is designed for regional- and national-scale mineral resource and mineral-environmental assessments.

\section{Descriptions of Map Sheets and Associated ERDAS Imagine Raster Image Files}

\section{Sheet 1 of 5}

Title: $\quad$ MAP OF MINERALOGY, VEGETATION, AND HYDROTHERMAL ALTERATION TYPE FROM ASTER SATELLITE IMAGERY WITH EXAMPLES FROM THE SAN JUAN MOUNTAINS, COLORADO

\author{
Subtitle: CONTINUOUS-TONE MAP OF MINERAL \\ GROUPS
}

Filename: sanjuans_aster_minvue468_pt-utm.img

\section{Description}

This image consists of three enhanced, shortwave-infrared (SWIR) bands $(4,6$, and 8$)$ of a single ASTER dataset covering the scene. The three ASTER bands have been saturation enhanced and sharpened to 15-m spatial resolution using edgeenhanced ASTER band 2 to modulate intensity (brightness).

\section{Purpose}

The purpose of the image is to enable the visual discrimination of mineral groups and other surface features. When the provided bands $(4,6$, and 8$)$ are displayed as a color composite (468/RGB, or 123/RGB for this dataset) the colors can be interpreted according to the guide given below.

Magenta: minerals with $\mathrm{Al}(\mathrm{Fe})-\mathrm{OH}$ or bound water SWIR absorptions (clays, sulfates, and white micas).

Red: minerals with $\mathrm{Al}(\mathrm{Fe})-\mathrm{OH}$ or bound water SWIR absorptions + ferric iron \pm minor carbonate \pm dry vegetation. Dark red indicates green vegetation (brightness reduced by using the red wavelengths of ASTER band 2, in which green vegetation shows deep chlorophyll absorptions and is thus dark, to modulate intensity).

Orange to reddish orange: dry vegetation \pm minor Al-OH minerals \pm minor carbonate.

Brown to reddish brown: green vegetation.

Yellow/green: carbonate minerals (for example, calcite and dolomite) will more likely have a yellowish hue; chlorite, epidote and (or) amphiboles with ferric/ferrous iron absorptions are more likely to have a greenish hue. Yellow indicates strong absorption in ASTER band 8, typical of unaltered carbonate rocks devoid of clay, mica, and ferric iron minerals. Green indicates absorption in ASTER bands 4 and 8 relative to band 6, typical of $\mathrm{Mg} / \mathrm{Fe}-\mathrm{OH}$ minerals such as chlorite and epidote which are common components of propylitic alteration (often intimately mixed with calcite). The absorption in band 4 of epidote and chlorite is caused by ferric and (or) ferrous iron. Dense, dry vegetation typically has less absorption (is brighter) in band 4 than chlorite and epidote, although it also has deep absorptions in band 8 .

White: High-albedo surfaces such as playas which may contain clays, micas, and (or) other minerals.

\section{Sheet 2 of 5}

Title: MAP OF MINERALOGY, VEGETATION, AND HYDROTHERMAL ALTERATION TYPE FROM ASTER SATELLITE IMAGERY WITH EXAMPLES FROM THE SAN JUAN MOUNTAINS, COLORADO 
Subtitle: IRON-BEARING MINERALS, VEGETATION, AND WATER

Filename: sanjuans_aster_fe-veg-water_pt-utm.img

\section{Description}

This image shows iron-bearing minerals, vegetation groups, and water identified using ASTER data based on spectral similarity between image spectra and laboratory reference spectra of well-characterized materials and material mixtures. Calibration and analysis of ASTER data were performed using methodologies described by Rockwell (2009). Colluvium (see http://static.panoramio.com/photos/original/4408546.jpg) on the northern and western flanks of Engineer Mountain derived primarily from unaltered mid-Tertiary intrusive rocks on the mountain summit was used for reflectance calibration of the ASTER data.

\section{Purpose}

The purpose of the image is to display the spatial distributions of iron-bearing minerals, vegetation groups differentiated by variations in chlorophyll content and dryness, and volatiles (water and snow). Most ferric iron associated with hydrothermal alteration or oxidized pyritic mine waste is shown in shades of red. Minor ferric iron associated with lithology and (or) weathering of iron-bearing minerals is shown in shades of orange. The image has been attributed by pixel value with material identification data that can be queried in most image processing and GIS software packages. Metadata includes pixel values associated with each identified material.

\section{Sheet 3 of 5}

Title: MAP OF MINERALOGY, VEGETATION, AND HYDROTHERMAL ALTERATION TYPE FROM ASTER SATELLITE IMAGERY WITH EXAMPLES FROM THE SAN JUAN MOUNTAINS, COLORADO

\section{Subtitle: CLAY, SULFATE, MICA, CARBONATE, MG-OH, AND HYDROUS QUARTZ MINERALS}

Filename: sanjuans_aster_swir_pt-utm.img

\section{Description}

This image shows clay, sulfate, mica, carbonate, $\mathrm{Mg}-\mathrm{OH}$, and hydrous quartz minerals identified using ASTER data based on spectral similarity between image spectra and laboratory reference spectra of well-characterized materials and material mixtures. Analysis of ASTER scene performed using methodologies described by Rockwell (2009).

\section{Purpose}

The purpose of the image is to display the spatial distributions of clay, sulfate, mica, carbonate, $\mathrm{Mg}-\mathrm{OH}$, and hydrous quartz minerals. The image has been attributed by pixel value with material identification data that can be queried in most image processing and GIS software packages. Metadata includes pixel values associated with each identified material.

Comments: Pixels colored light purple were spectral matches to an iron-rich muscovite (sample GDS116 Tanzania see http://speclab.cr.usgs.gov/spectral.lib06/ds231/PLOTS/M/ muscovite gds116.15173.w1.gif, Clark and others, 2007), and have been labeled as "Fe/Mg sericite, or muscovite + chlorite mixture." Figure 1, line a, shows the reference spectrum of this muscovite convolved to ASTER spectral resolution. The iron in the crystal structure shifts the position of the primary Al-OH absorption near $2.2 \mu \mathrm{m}$ (micrometers) to somewhat longer wavelengths $(2.215 \mu \mathrm{m}$ and longer) than in aluminumrich muscovites, and also produces minor absorption near $2.245 \mu \mathrm{m}$ that results in an asymmetric shape of the $\mathrm{Al}-\mathrm{OH}$ feature. At ASTER resolution, these spectral characteristics are manifested by reduced reflectance near $2.27 \mu \mathrm{m}$ (ASTER band 7) relative to that of ASTER band 5 (see black arrows in fig. 1), and generally low reflectance of bands 6-9 compared to that of band 5. Figure 1 line $d$ shows an average spectrum of several ASTER pixels that were matched to the GDS116 muscovite reference spectrum. ASTER and AVIRIS spectra of iron-rich muscovites are compared in Rowan and Mars (2003).

The laboratory spectrum of a chlorite + muscovite mixture convolved to ASTER resolution is shown in line $b$ of figure 1. This spectrum also shows reduced reflectance at ASTER band 7 and is very close in overall SWIR shape to that of the ASTER spectrum in line d. The iron- and (or) magnesium-related absorptions in chlorite near $2.25 \mu \mathrm{m}$ also result in decreased reflectance at ASTER band 7. The similarities in SWIR shape of iron-rich muscovites (figure 1line a) and chlorite + muscovite mixtures (figure 1 , line b) at ASTER spectral resolution prevent accurate discrimination from each other. Spectral similarities between chlorite + muscovite mixtures and low-aluminum (iron- and magnesium-bearing) muscovites have also been observed in AVIRIS data (Rockwell and others, 2005).

The pixels matched to iron-rich muscovite (fig. 1, line d) are located along the western edge of the Silverton caldera in rocks that have undergone regional propylitic alteration to sericite and chlorite ( \pm minor calcite) associated with lava degassing and caldera development (Bove and others, 2007; Yager and others, 2005). This alteration corresponds to the chlorite-illite-calcite, or CIC, type of propylitic alteration characterized by Bove and others (2008) which is commonly epidote-poor and in some cases represents a younger overprint of weak sericite-pyrite alteration on regionally propylitized rocks. The sericite (illite) commonly replaces chlorite in such cases. The lack of substantial absorption at ASTER band 7 indicates a lower concentration of calcite, chlorite, and epidote relative to sericite, in contrast to higher-grade, proximal 


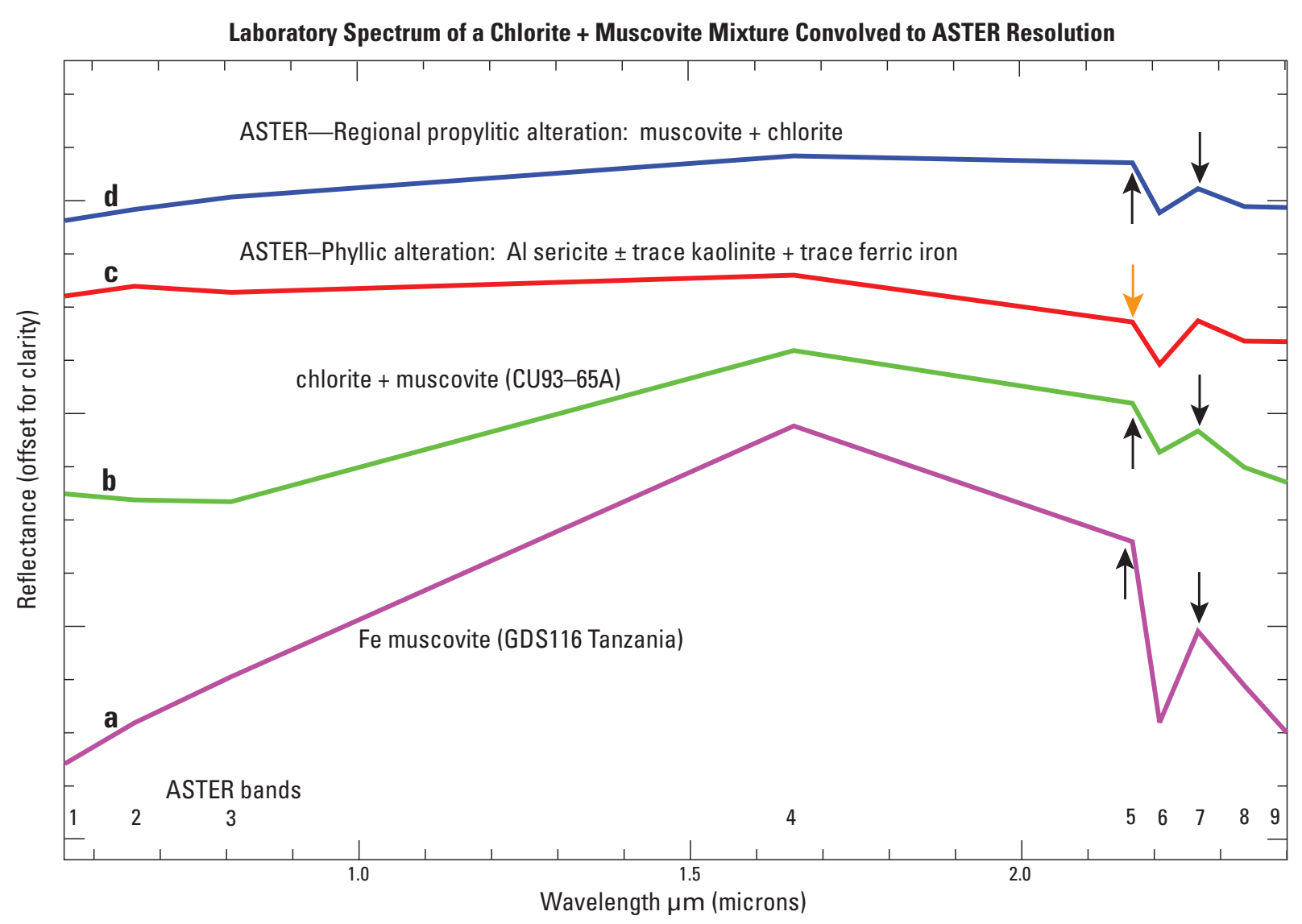

Figure 1. Plots of laboratory reference spectra (Clark and others, 2007) convolved to ASTER spectral resolution and ASTER pixel spectra of muscovites and a muscovite + chlorite mixture. ASTER band centers are shown along the bottom. Click on figure for more detailed image.

propylitic alteration (chlorite-epidote-calcite or CEC alteration of Bove and others, 2008) surrounding hydrolytic alteration located near the center of the caldera. Aluminum-rich sericite associated with phyllic (quartz-sericite-pyrite) alteration (fig. 1, line c) shows higher reflectance in ASTER band 7 relative to that of band 5, an effect which is made more pronounced by trace amounts of supergene kaolinite which reduce reflectance in band 5 (fig 1, orange arrow).

The AVIRIS-based mapping of Dalton and others (2004) does not discriminate sericites based on composition, as all identified sericites not mixed with clays, carbonates, chlorite, or epidote were combined into a single sericite class. The ASTER-based mapping shown here demonstrates that distal, regional propylitic alteration with abundant sericite and minor chlorite and calcite can be distinguished from higher-grade, proximal propylitic alteration with more abundant calcite, chlorite, and epidote. The acid neutralizing capacity (ANC) of the latter, proximal type of propylitic alteration is most likely greater than that of the former, distal type. Sheet 3 shows that mixtures of calcite ( \pm minor chlorite and epidote) and sericite (or smectite) are directly identified and shown in bluish green, in addition to "pure" calcite (bright green) and dolomite (dark green). Calcite + dolomite mixtures may be similar in SWIR spectral shape to epidote, and are thus not differentiated (pixels matched to epidote are shown in blue but labeled as either epidote or calcite + dolomite mixture) (Rockwell, 2009). Not many pixels of "pure" chlorite (shown in faded light green) were identified because the deep ferric and (or) ferrous iron absorptions of chlorite in the visible and near-infrared (VNIR) were included in the spectral matching process, meaning that both the VNIR and SWIR features had to match the reference spectrum for a pixel to be identified as chlorite. Such VNIR absorptions are not present in calcite and are not included in the spectral matching of epidote, making identifications of those minerals more likely than chlorite. The iron-related VNIR absorptions of epidote are relatively weak compared to those of chlorite, and are thus easily masked in remote sensing data by vegetation and other spectral mixing effects.

The smectite group mineral montmorillonite occurs as a primary or diagenetic constituent in various rock types, including ash-flow tuffs which are common in the San Juan Mountains. Montmorillonite also occurs in peripheral parts of argillic and phyllic alteration zones from hydrothermal fluids of near-neutral $\mathrm{pH}$ and lower temperatures. Sericite in low abundance may be misidentified as montmorillonite, as the Al-OH absorption feature of sericite at ASTER band $8(2.336 \mu \mathrm{m})$ may 
be too shallow to be detectable using ASTER SWIR data. In the Silverton caldera, most low-abundance sericite is associated with weakly propylitized volcanic rocks, although it is common in many un-altered rock types including shales, quartzites, and granites.

ASTER SWIR data become unstable at low surface albedos (for example, terrain and cloud shadow) and spurious spectral shapes are present in such areas which may mimic those of minerals and other surface features. The spectral shapes common to iron-rich muscovites and sericite + chlorite mixtures are common in such low-albedo areas. Masking of low-albedo areas prior to analysis is vital to remove false muscovite detections in these areas.

Several pixels of hydrous silica (chalcedony or opal) were identified within a silicified breccia body (Bove and others, 2007) immediately southwest of the summit of Red Mountain No. 3.

\section{Sheet 4 of 5}

Title: MAP OF MINERALOGY, VEGETATION, AND HYDROTHERMAL ALTERATION TYPE FROM ASTER SATELLITE IMAGERY WITH EXAMPLES FROM THE SAN JUAN MOUNTAINS, COLORADO

Subtitle: MODELED HYDROTHERMAL ALTERATION TYPE

Filename: sanjuans_aster_alteration5_pt-utm.img

\section{Description}

This image shows the results of a new methodology designed to simplify and combine the mineral occurrence information contained in sheets 2 and 3 into a single map showing the spatial distribution of hydrothermal alteration types and (or) carbonate rocks. Although carbonate rocks can be isolated from propylitic alteration through integration with a digital lithologic map, carbonate rocks are included because of their strong acid neutralizing capacity importance to geoenvironmental modeling. In the map explanation, alteration types and key mineral assemblages have been grouped by relative NAP and ANC. These groups are ordered by decreasing NAP from upper left to lower right.

Hydrothermal alteration types are defined based on the presence of mineral assemblages, and diagnostic minerals for such definitions are remotely identified from both the visible/ near-infrared (VNIR, sheet 2) and SWIR (sheet 3) spectral regions which are analyzed separately. Therefore, a suite of Boolean equations was developed that combines the mineralogic information from the two spectral regions (table 1).

As aluminum-rich sericite associated with hydrothermal alteration is commonly present in greater spectral abundance (greater absorption feature depth given equivalent grain size) than sericite in unaltered sedimentary and metamorphic rocks, sericite identified using the ASTER data was subdivided into groups of high and low abundance. Sericite with greater feature depths was assigned to the high abundance group, and sericite with lesser feature depths was assigned to the low abundance group. Low-abundance sericite was included in the Boolean formulae used to compute alteration types only when in the presence of ferric iron, in which case the combination was classified as "regional propylitic to weak QSP - minor sericite + ferric iron" ("QSP" refers to quartz-sericite-pyrite, or phyllic, alteration).

The kaolinite + smectite mixture was assigned to the phyllic alteration type if it occurred in the presence of ferric iron (shaded cell in table 1) even though the mixture is an argillic assemblage. Supergene weathering of pyritic rocks typically produces a poorly crystallized argillic overprint containing kaolinite \pm smectite (Rockwell and others, 2005; Cunningham and others, 2005) and abundant ferric iron minerals including jarosite and goethite. Rockwell (2009) shows that a kaolinite + smectite mixture and abundant ferric iron (in addition to gypsum) were detected in weathered, highly pyritized, phyllicallyaltered dacite lava flows on Big Rock Candy Mountain in the Marysvale volcanic field, Utah, using ASTER data.

\section{Purpose}

This image shows the occurrence of hydrothermal alteration types and carbonate rocks. The image provides an effective, more easily interpretable tool for geologists, watershed modelers, and land managers, The data can be readily integrated with other data layers in a GIS environment for the purposes of geoenvironmental watershed modeling. Each alteration type or mineral group can be attributed with values representing relative net acid production (acid producing potential) and acid neutralizing capacity.

Comments: This map is compared to alteration maps produced from integrated AVIRIS data analysis and field mapping (Bove and others, 2007) by Rockwell (2010b).

\section{Sheet 5 of 5}

Title: MAP OF MINERALOGY, VEGETATION, AND HYDROTHERMAL ALTERATION TYPE FROM ASTER SATELLITE IMAGERY WITH EXAMPLES FROM THE SAN JUAN MOUNTAINS, COLORADO

Subtitle: MODELED HYDROTHERMAL ALTERATION TYPE, MINERAL GROUPS, AND GREEN VEGETATION GENERATED BY AUTOMATED ANALYSIS

Filename: sanjuans_aster_autoalt55_merge_pt-utm.img

\section{Description}

This image shows the results of a new methodology designed for the automated identification and mapping of 
Table 1. Boolean logic used to combine results of separate iron mineral, vegetation, and water analysis (mainly VNIR absorptions, see sheet 2) and clay, sulfate, mica, carbonate, and hydrous silica mineral analysis (mainly SWIR absorptions, see sheet 3) into a single map of hydrothermal alteration type (see sheet 4).

\begin{tabular}{|c|c|c|c|c|c|c|c|c|c|c|c|c|c|c|c|c|c|c|c|c|c|}
\hline & \multicolumn{4}{|c|}{$\begin{array}{l}\text { Iron mineral, vegetation, } \\
\text { and water analysis }\end{array}$} & \multicolumn{17}{|c|}{ VNIR-SWIR mineral analysis } \\
\hline & $\begin{array}{c}\text { major } \\
\text { ferric } \\
\text { iron }\end{array}$ & $\begin{array}{c}\text { minor } \\
\text { ferric } \\
\text { iron }\end{array}$ & $\begin{array}{l}\text { copiapite } \\
\text { (possible) }\end{array}$ & $\begin{array}{c}\text { sericite } \\
+ \\
\text { chlorite }\end{array}$ & $\begin{array}{c}\text { kaolinite } \\
+ \\
\text { smectite }\end{array}$ & alunite & $\begin{array}{c}\text { alunite } \\
+ \\
\text { kaolinite }\end{array}$ & \begin{tabular}{|c|} 
natroalunite \\
or alunite \\
+ minor \\
kaolinite
\end{tabular} & pyrophyllite & $\begin{array}{c}\text { kandite } \\
\text { clay }\end{array}$ & $\begin{array}{c}\text { kaolinit } \\
+ \text { sericite }\end{array}$ & $\begin{array}{c}\mathrm{Al} \\
\text { sericite }\end{array}$ & $\begin{array}{c}\mathrm{Fe} / \mathrm{Mg} \\
\text { sericite,or } \\
\text { muscovite } \\
+ \text { chlorite }\end{array}$ & $\begin{array}{c}\text { hydrous } \\
\text { silica (or } \\
\text { jarosite }+ \\
\text { sericite or } \\
\text { smectite) }\end{array}$ & jarosite & smectite & calcite & dolomite & \begin{tabular}{|c} 
epidote, \\
or \\
calcite \\
+ \\
dolomite
\end{tabular} & chlorite & $\begin{array}{l}\text { calcite } \\
+ \\
\text { sericite }\end{array}$ \\
\hline Advanced argillic & & & & & & OR & OR & OR & OR & & & & & & & & & & & & \\
\hline $\begin{array}{c}\text { Argillic (or clay- } \\
\text { bearing rocks) }\end{array}$ & NOT & NOT & NOT & & OR & & & & & OR & OR & & & & & OR & & & & & \\
\hline $\begin{array}{l}\text { Argillic + ferric } \\
\text { iron }\end{array}$ & OR & OR & OR & & & & & & & OR & & & & & & OR & & & & & \\
\hline Hydrous silica & NOT & NOT & NOT & & & & & & & & & & & AND & & & & & & & \\
\hline Phyllic (QSP) & OR & OR & OR & & OR & & & & & & OR & $\left|\begin{array}{c}\text { OR (high } \\
\text { abundance) }\end{array}\right|$ & & & & & & & & & \\
\hline $\begin{array}{l}\text { Highly pyritic } \\
\text { QSP +/- } \\
\text { hydrous silica }\end{array}$ & OR & OR & OR & & & & & & & & & & & AND & & & & & & & \\
\hline Pyritic (jarosite) & & & & & & & & & & & & & & & $\mathrm{x}$ & & & & & & \\
\hline $\begin{array}{l}\text { Propylitic or } \\
\text { carbonate rocks }\end{array}$ & NOT & NOT & NOT & & & & & & & & & & & & & & OR & OR & OR & OR & \\
\hline $\begin{array}{l}\begin{array}{l}\text { Propylitic }+ \\
\text { sericite }\end{array} \\
\end{array}$ & NOT & NOT & NOT & & & & & & & & & & & & & & & & & & AND \\
\hline $\begin{array}{r}\text { Propylitic }+ \\
\text { ferric iron } \\
\end{array}$ & OR & OR & OR & & & & & & & & & & & & & & OR & OR & OR & OR & \\
\hline $\begin{array}{c}\text { Propylitic }+ \\
\text { sericite }+ \\
\text { ferric iron } \\
\end{array}$ & OR & OR & OR & & & & & & & & & & & & & & & & & & AND \\
\hline $\begin{array}{l}\text { Regional } \\
\text { propylitic to } \\
\text { weak QSP } \\
\end{array}$ & OR & OR & OR & & & & & & & & & $\begin{array}{c}\text { AND (low } \\
\text { abundance) }\end{array}$ & & & & & & & & & \\
\hline $\begin{array}{l}\text { Regional } \\
\text { propylitic }\end{array}$ & & & & & & & & & & & & & $\mathrm{X}$ & & & & & & & & \\
\hline
\end{tabular}


mineral groups and green vegetation from ASTER data at regional to national scales. Detailed description of this methodology is provided in the following section. These results were modeled using Boolean algebra from the raw results of the ratio-based analysis algorithm, which are also provided (sanjuans_aster_autoalt54_pt-utm.img). The 23 output classes are ordered relative to decreasing assumed net acid production from upper left (high) to lower right (low). Note that although ferrous iron itself has little to no acid neutralizing capacity (ANC), it is often associated with chlorite-, epidote-, and (or) carbonate-bearing rocks which can have substantial ANC Yager and others, 2008).

\section{Purpose}

This image shows the occurrence of alteration types, mineral groups, and dense green vegetation. The image provides an easily interpretable tool for geologists, watershed modelers, and land managers engaged in geoenvironmental watershed modeling and mineral resource assessment at regional to national scales. The image has been attributed by pixel value with material identification data that can be queried in most image processing and GIS software packages. Metadata includes pixel values associated with each identified material.

\section{Description of Automated Analysis Methodology}

To efficiently generate uniform maps of minerals and hydrothermal alteration over very large areas using ASTER data, automated processing and analysis techniques are required. As such, the analysis must accurately identify exposed minerals or mineral groups (minerals having similar spectral properties given the spectral resolution of the data being analyzed) from any suitable ASTER scene in any climate or terrain with no operator interaction. Suitable scenes are those with minimal cloud, haze, dust, and snow cover and maximal solar illumination (high solar elevation angle during late spring to early autumn).

The methodology presented here involves the use of compound band ratios to identify areas where one or more specific spectral absorption features are present. Ratios were developed to identify mineral groups based on diagnostic absorptions of pure and mixed mineral species in laboratory reference spectra convolved to ASTER spectral resolution. The technique assumes that only a particular mineral or mineral group (or green vegetation) will have deep absorption at a particular wavelength interval (one or more adjacent ASTER bands). If another surface material, material mixture, or feature has deep absorption at a given wavelength interval, a false detection of a mineral group will occur. The utility of a ratio of type $(x+y) / z$ to identify absorption at band $\mathrm{z}$ relative to adjacent bands $\mathrm{x}$ and y was first demonstrated by Crowley and others (1989), who termed the technique "relative band depth" mapping. Some of the same ratios have been used previously to map minerals and mineral groups using ASTER data (Rowan and Mars, 2003).

Prior to computing the material indices described below, the ASTER VNIR data are resampled to 30-m spatial resolution to match that of the SWIR data, and all data are converted to scaled, 16-bit radiance units through multiplication of gain values that are documented in the scene metadata. No further corrections are applied to the data. Cross-talk corrections (Iwasaki and Tonooka, 2005) are not applied to the data for four reasons. First, the cross-talk error does not cause significant spectral corruption except in areas where there is extreme variation in surface albedo, such as in transitions between bright land surfaces and large bodies of water. Second, correction software for this error available from the Earth Remote Sensing Data Analysis Center (http://www.gds.aster.ersdac.or.jp/gds www2002/service_e/release_e/set_release_ecrs.html) does not fully correct the crosstalk effects, and introduces random noise to the SWIR data. Third, the software is designed to operate on ASTER Level 1B data in Hierarchical Data Format (HDF), and the use of orthocorrected Level 3 AST14OTH data, which is in geotiff rather than HDF format, is required for efficient product generation over large regions. And fourth, the software is difficult to integrate with the automated processing stream being developed for regional- and national-scale analysis.

All analytical processing described below is performed in one pass, producing two output files. The first is a nine-band binary file containing the material indices, and the second is a single-band, GIS-ready, attributed file of the merged results (sheet 5). This processing takes 75 seconds per ASTER scene on an Intel Core i7 Gulftown processor running at 3.7 GHz.

\section{Mineral Group and Green Vegetation Indices}

The nine indices described below are contained in the nine bands of the file "sanjuans_aster_autoalt54_pt-utm.img" provided with this publication. Information regarding the spectral and spatial characteristics of ASTER data is provided by Rockwell (2009). In the formulas for the indices, ASTER bands are indicated in bold. Rockwell (2010b) compares the results of several of the indices to detailed mineral maps produced from ASTER (sheets 2-4) and AVIRIS data.

\section{Ferric Iron 1 “Redness" Index}

An ASTER 2/1 ratio is used to highlight areas that have absorption in ASTER band 1 (green wavelengths) relative to band 2 (red wavelengths) (fig. 2). Ferric iron minerals are characterized by deep charge-transfer absorptions in the ultraviolet $(<0.4 \mu \mathrm{m})$ (Clark, 1999). The long-wavelength side of this absorption extends into the visible, absorbing blue and some green light and creating the characteristic red, orange, and yellow colors of such minerals. This ratio is similar to the red/blue ratio commonly used to identify ferric iron with Landsat Thematic Mapper data (3/1 ratio). The utility of the $2 / 1$ ratio for mapping ferric iron occurrence was demonstrated by Rowan and Mars (2003). 


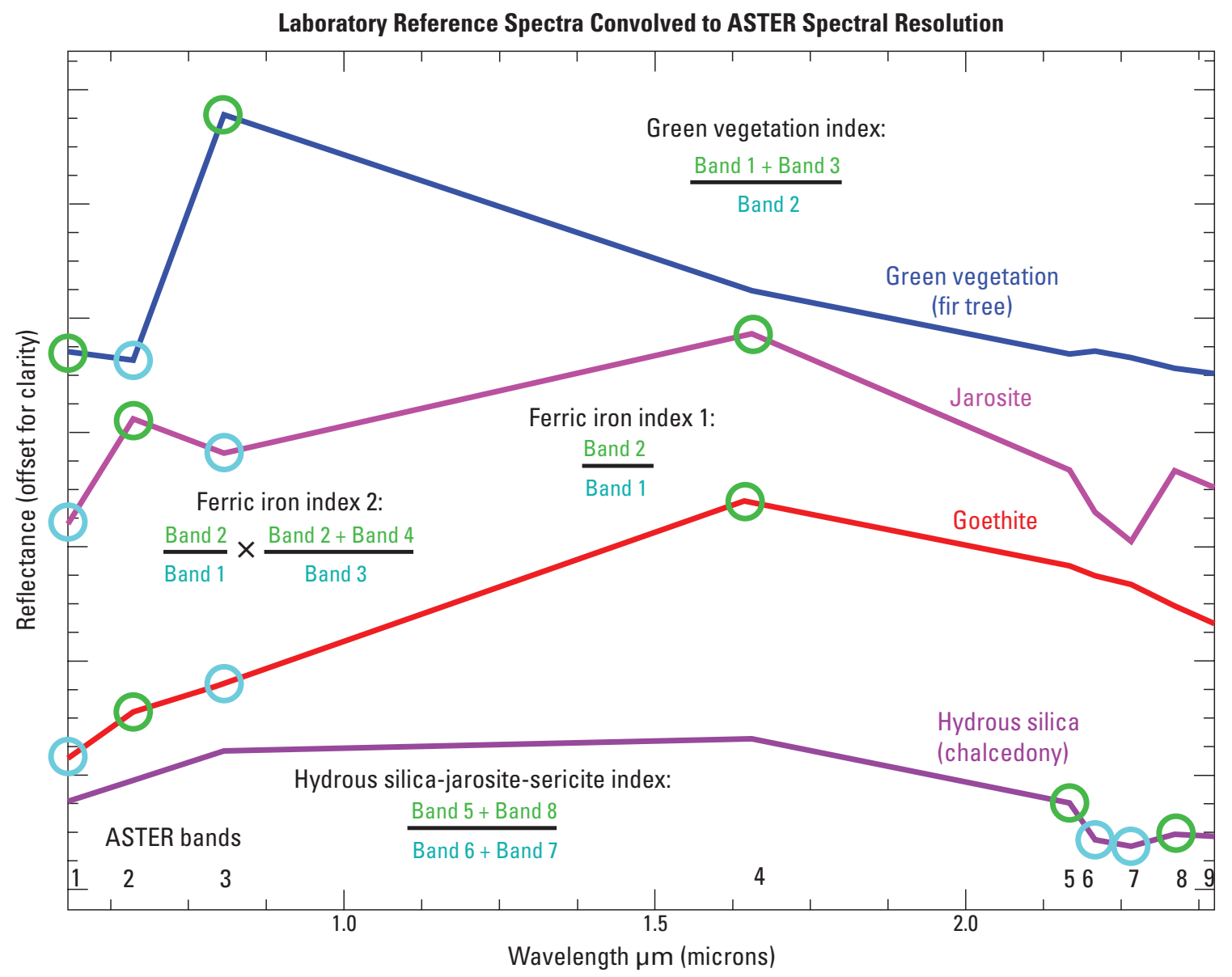

Figure 2. Plots of laboratory reference spectra (Clark and others, 2007) convolved to ASTER spectral resolution. Plots are annotated with circles indicating ASTER bands used in the material indexes. Green circles show bands used in the numerator of an index, and cyan circles show bands used in the denominator. ASTER band centers are shown along the bottom. Click on figure for more detailed image.

Jarosite will generally have deeper absorption at band 1 compared to goethite (fig. 2), both minerals are common in weathered pyritic rocks. Most hematites will also show less band 1 absorption than jarosite. However, this index will highlight areas in which any ferric iron mineral (including jarosite, goethite, and hematite) occurs pervasively or as coatings. Ferric iron-bearing surfaces of hydrothermally altered rocks, sedimentary rocks such as red beds and arkoses, metamorphic rocks containing weathered, iron-bearing mafic minerals such as hornblende and biotite, sand deposits, and alluvium derived from such rocks will be identified with this index. The index is sensitive to ferric iron even in low concentrations.

\section{Ferric Iron Index 2}

An ASTER $(\mathbf{2} / \mathbf{1}) \times(0.5 \times((\mathbf{2}+\mathbf{4}) / \mathbf{3})$ compound ratio is used to highlight ferric iron-bearing areas in which crystalfield absorptions in the near infrared (ASTER band 3) are present in addition to the charge transfer absorptions previously described (2/1 ratio). Figure 2 shows that the crystalfield absorptions in jarosite are significantly deeper than those of goethite, although the VNIR spectral characteristics of ferric iron minerals vary greatly relative to abundance and grain size (Rockwell, 2004). Since this ratio contains the $\mathbf{2} / \mathbf{1}$ operator of ferric iron index 1, pixels with high ratio values will be a subset of those highlighted by ferric iron index 1 . Ferric iron index 2 will identify areas in which ferric iron minerals are present in greater abundance than ferric iron index 1, and these areas will in most cases be surrounded by pixels highlighted by ferric iron index 1 .

\section{Advanced Argillic-Kandite Index}

Alunite and pyrophyllite are common components of advanced argillic alteration, and have vibrational Al-OH absorption in the SWIR at ASTER band 5 (fig. 3). Kandite 


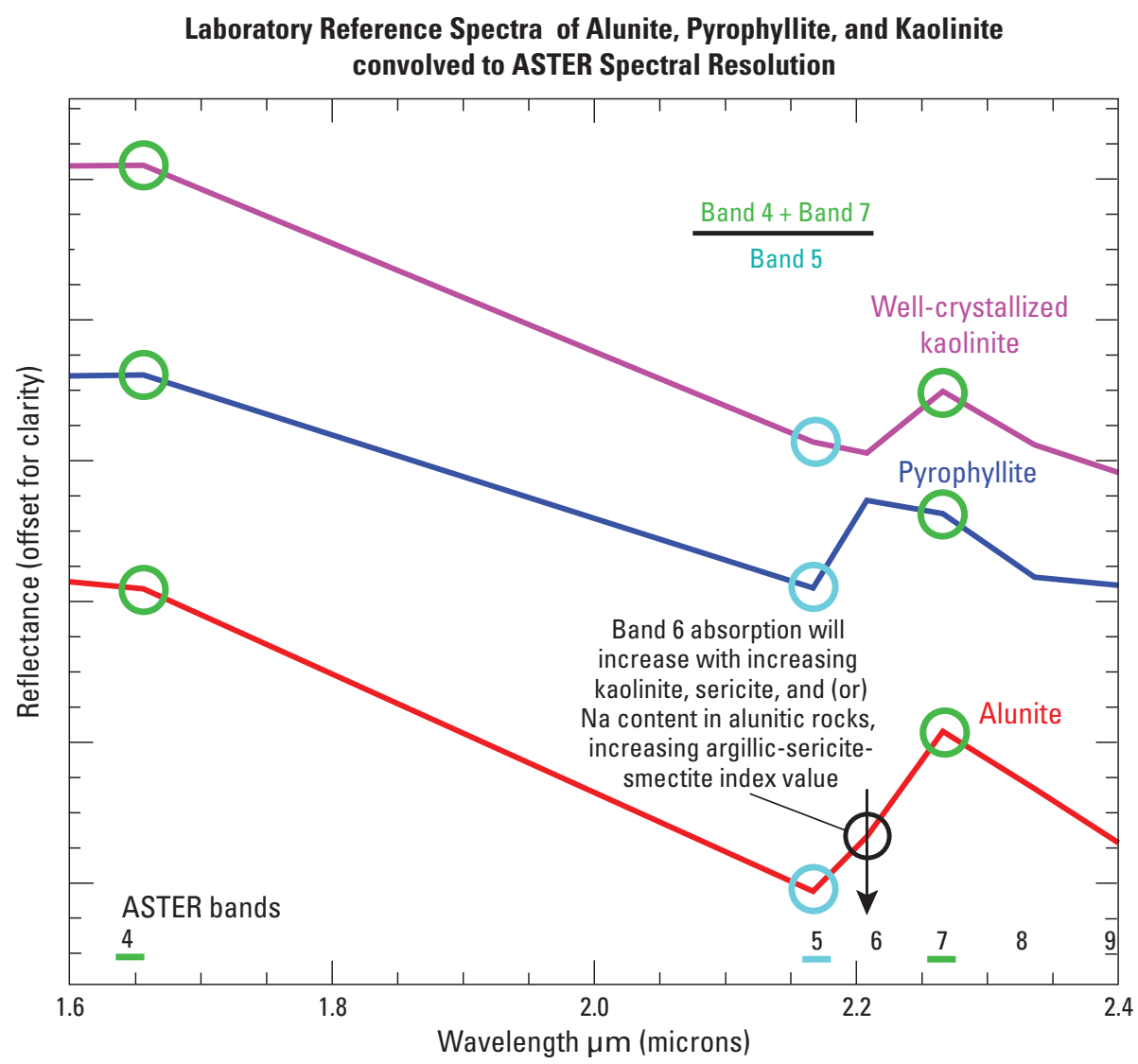

Figure 3. Plots of laboratory reference spectra of alunite, pyrophyllite, and kaolinite (Clark and others, 2007) convolved to ASTER spectral resolution. Plots are annotated with circles indicating ASTER bands used in the advanced argillic-kandite index. Green circles show bands used in the numerator of an index, and cyan circles show bands used in the denominator. ASTER band centers are shown along the bottom. Click on figure for more detailed image.

clay minerals such as kaolinite and dickite may occur mixed with and peripheral to alunite and pyrophyllite in advanced argillic alteration zones from fluids of higher $\mathrm{pH}$ and lesser temperature (Rockwell and others, 2006). Kandite clay minerals also have absorption ASTER band 5, although of a lesser depth (Rockwell, 2009). An ASTER (4+7)/5 ratio is used to highlight these absorptions.

Dry vegetation has deep lignin-cellulose absorptions at ASTER bands 5 and 7 and 8 (Rockwell, 2009 and references therein). When sparse dry vegetation is present on surfaces underlain by kaolinite- or sericite-bearing rocks, the vegetation absorption mixes with the mineral absorptions and produces spectra that can be similar in appearance to that of alunite and pyrophyllite, creating severe problems for the accurate mapping and characterization of advanced argillic and argillic alteration (John and others, 2010). To mitigate the deleterious spectral effect of dry vegetation, the $(\mathbf{4 + 7}) / \mathbf{5}$ ratio is divided by the $(\mathbf{6}+\mathbf{9}) /(\mathbf{7}+\mathbf{8})$ ratio (which highlights absorption in bands 7 and 8), resulting in the highlighting of areas in which only band 5 absorption occurs.

\section{Argillic-Sericite-Smectite Index}

Sericite, smectite, and kandite clay minerals such as kaolinite have vibrational Al-OH absorption features near ASTER band 6 (fig. 4). Kandite clay minerals have weaker absorption at band 6 compared to sericite and smectite. An ASTER (5+7)/6 ratio is used to highlight these absorptions. The utility of this ratio for mapping aluminum-rich muscovites was demonstrated by Rowan and Mars (2003). Figure 3 shows that kaolinite also has absorption at ASTER bands 5 . Therefore, kandite clay minerals will typically be highlighted by both the advanced argillic-kandite and argillic-sericitesmectite indices. 


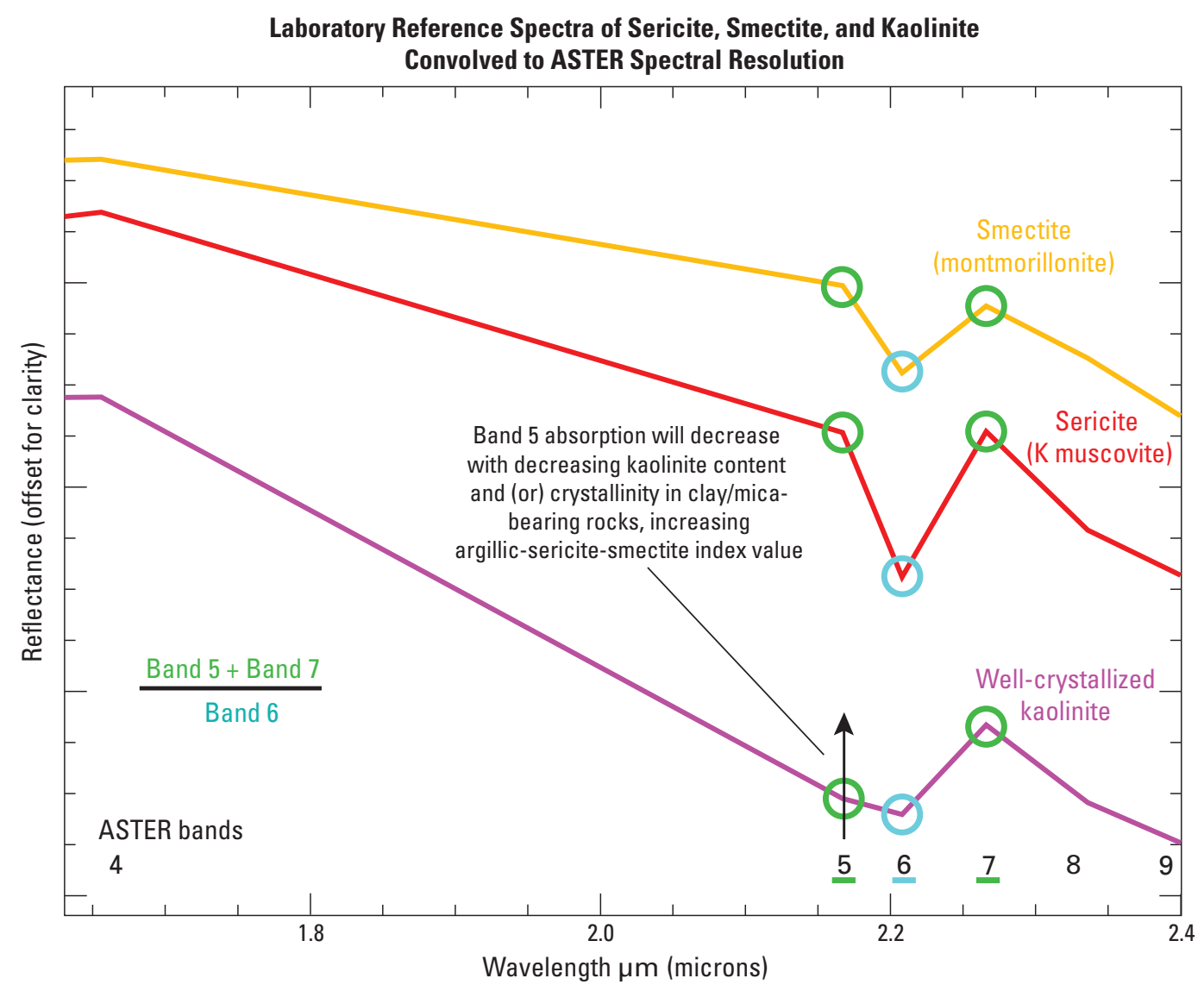

Figure 4. Plots of laboratory reference spectra of sericite, smectite, and kaolinite (Clark and others, 2007) convolved to ASTER spectral resolution. Plots are annotated with circles indicating ASTER bands used in the argillic-sericite-smectite index. Green circles show bands used in the numerator of an index, and cyan circles show bands used in the denominator. ASTER band centers are shown along the bottom. Click on figure for more detailed image.

Absorption at band 6 will increase with increasing kandite clay, sericite, and (or) Na content in alunitic rocks, increasing the argillic-sericite-smectite index value (fig. 3; Rockwell 2009). Therefore, advanced argillic alteration with significant kandite clay, sericite, and (or) Na content will likely be highlighted by both indices, whereas K-rich alunite and pyrophyllite with minimal clay or sericite will most likely be highlighted only by the advanced argillic-kandite index.

In clay- and (or) mica-bearing rocks, band 5 absorption will decrease with decreasing kandite clay content, increasing the argillic-sericite-smectite index value and decreasing the advanced argillic-kandite index value (fig. 4). Kandite-poor surfaces with sericite and (or) smectite will thus be unlikely to be highlighted by the advanced argillic-kandite index.

\section{Carbonate-Propylitic Index}

Carbonates, chlorite, epidote, magnesium-bearing phyllosilicates such as talc and serpentine, and most amphiboles (for example, tremolite, actinolite, hornblende, cummingtonite) have vibrational absorptions near ASTER bands 7 and 8 related to bonds in $\mathrm{Fe}-\mathrm{OH}$ (band 7), and $\mathrm{CO}_{3}$ and $\mathrm{Mg}-\mathrm{OH}$ (band 8) molecules (Clark, 1999). Figure 5 shows laboratory reference spectra of some of these minerals convolved to ASTER spectral resolution. An ASTER $(\mathbf{6}+\mathbf{9}) /(\mathbf{7 + 8})$ ratio is used to highlight these absorptions. Carbonate-bearing sedimentary and metamorphic rocks and propylitically-altered igneous rocks will be highlighted with this index. Most of the minerals identified using this index have at least some acid neutralizing capacity, including some of the amphiboles (Jambor and others, 2002).

As explained above, dry vegetation with abundant lignin and (or) cellulose leaf biochemicals is characterized by prominent absorptions at ASTER bands 5 and 7-8. To minimize spectral confusion between dry vegetation and carbonate-propylitic minerals, the $(\mathbf{6}+\mathbf{9}) /(\mathbf{7}+\mathbf{8})$ ratio is divided by a $(4+7) / 5$ ratio to highlight areas in which only band $7-8$ absorption occurs. 


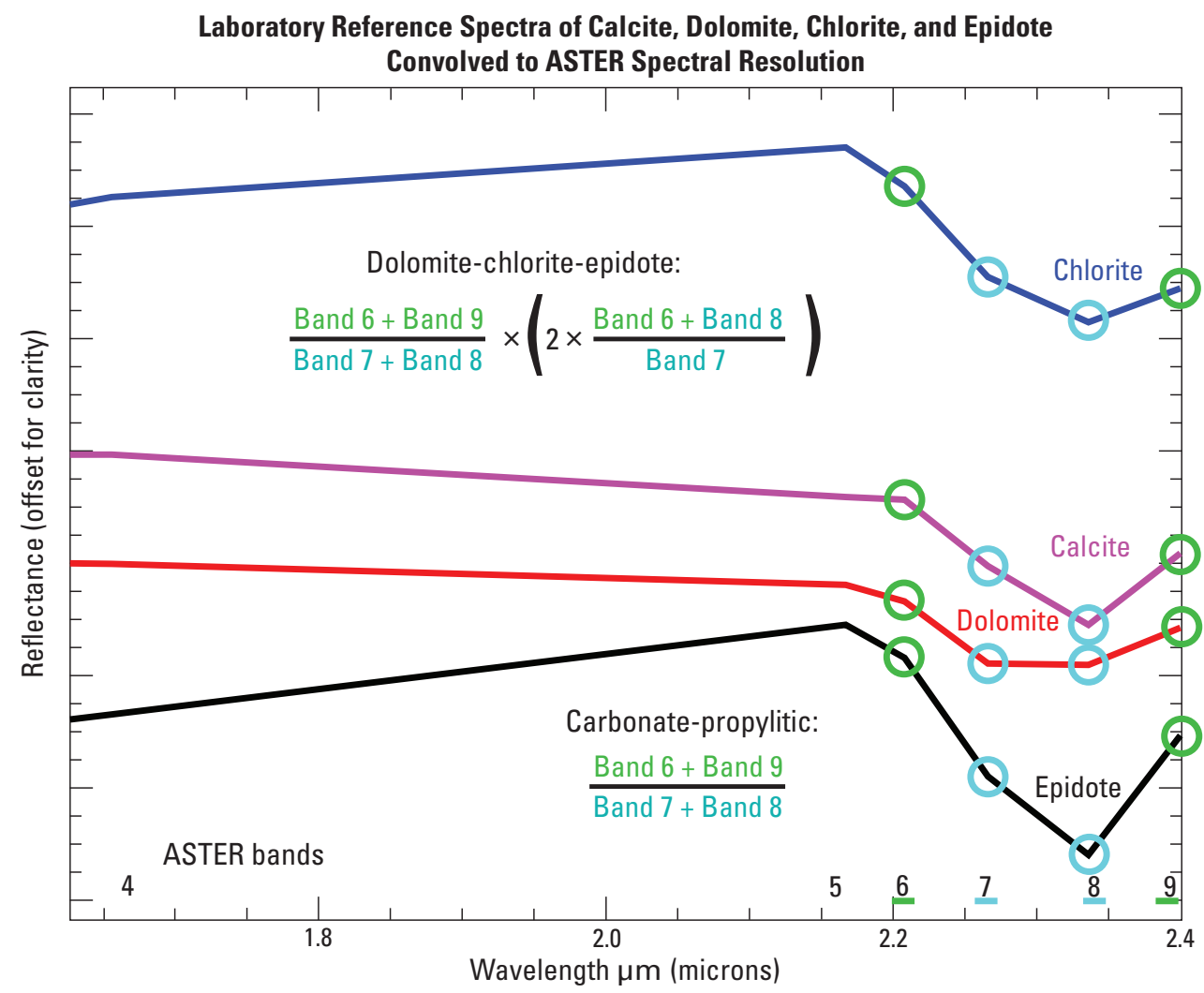

Figure 5. Plots of laboratory reference spectra of calcite, dolomite, chlorite, and epidote (Clark and others, 2007) convolved to ASTER spectral resolution. Plots are annotated with circles indicating ASTER bands used in the carbonate-propylitic and dolomite-chlorite-epidote indices. Green circles show bands used in the numerator of an index, and cyan circles show bands used in the denominator. ASTER band centers are shown along the bottom. Click on figure for more detailed image.

\section{Dolomite-chlorite-epidote index}

Figure 5 also shows that dolomite has absorption at ASTER band 7 that is deeper than in other carbonate-propylitic minerals. Of these minerals, band 7 absorption depth increases from calcite (low), to epidote, chlorite, and dolomite (high). The position and shape of the $\mathrm{Fe}-\mathrm{OH}$ absorption in chlorites near ASTER band 7 vary significantly relative to $\mathrm{Fe} / \mathrm{Mg}$ ratios. The absorption position shifts from $2.241 \mu \mathrm{m}$ in intermediate magnesium chlorites to $2.247 \mu \mathrm{m}$ in intermediate iron chlorites (Jones and others, 2005). It can be assumed that iron-rich chlorites will have slightly greater absorption at ASTER band 7 than magnesium-rich chlorites, as the absorption position in iron-rich chlorites is closer to the momentum center of band 7 $(2.266 \mu \mathrm{m})$.

$\mathrm{A}(6+9) /(7+8) \times(2 \times((6+8) / 7))$ compound ratio is used to highlight areas with significant band 7 absorption within carbonate and (or) propylitically-altered rocks. Such areas most likely correspond to dolomite in sedimentary rocks, and to chlorite and (or) epidote in metamorphic or propyliticallyaltered igneous rocks.
As with the carbonate-propylitic index, the ratio for the dolomite-chlorite-epidote index is divided by a $(\mathbf{4}+\mathbf{7}) / \mathbf{5}$ ratio to minimize spectral confusion with dry vegetation.

\section{Hydrous Silica-Jarosite-Sericite Index}

Hydrous silica minerals such as opal and chalcedony have vibrational Si-OH absorptions at ASTER bands 6 and 7, and jarosite has $\mathrm{Fe}-\mathrm{OH}$ absorptions in the same wavelength interval (figure 2). A $(\mathbf{5}+\mathbf{8}) /(\mathbf{6}+7)$ ratio is used to highlight areas in which such absorptions are present. Nonhydrous quartz in advanced argillic and phyllic alteration, quartzites, cherts, sand deposits, and perlitic volcanic rocks can be identified through analysis of the ASTER thermal infrared data (Rockwell and Hofstra, 2008).

Band ratios are an imprecise method of quantifying absorption feature shape compared to spectroscopic methods such as least-squares curve fitting (Clark and others, 1990), and matched-filtering (Harsanyi and Chang, 1994). When coupled with the low spectral resolution of ASTER data compared to that of laboratory and imaging spectrometers, band ratio results 


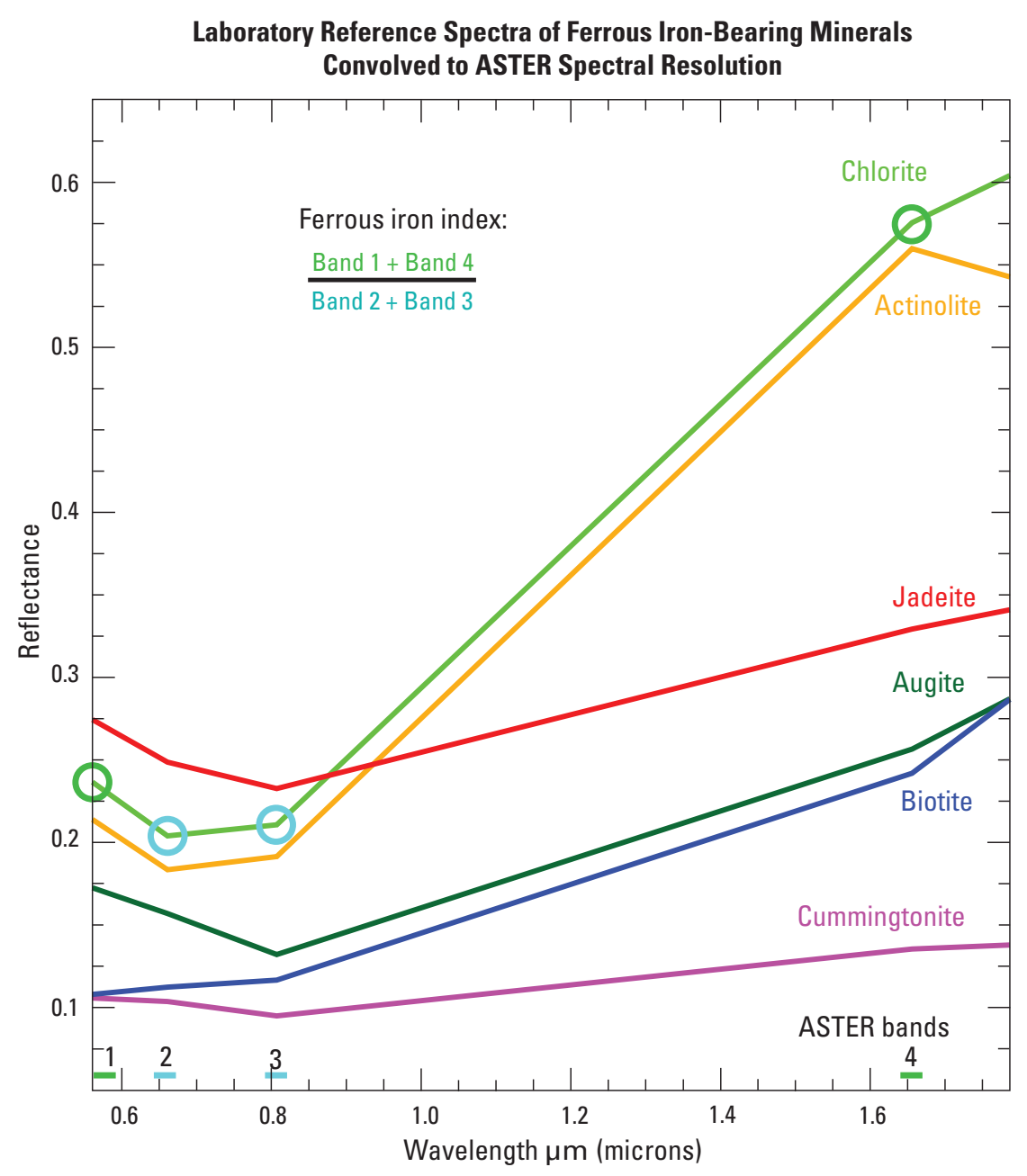

Figure 6. Plots of laboratory reference spectra of ferrous iron-bearing minerals (Clark and others, 2007) convolved to ASTER spectral resolution. The iron absorptions in chlorite are related to both ferric and ferrous iron. Plots are annotated with circles indicating ASTER bands used in the ferrous iron index. Green circles show bands used in the numerator of an index, and cyan circles show bands used in the denominator. ASTER band centers are shown along the bottom. Click on figure for more detailed image.

can show significant confusion between surface materials with similar spectral properties. The $(\mathbf{5}+\mathbf{8}) /(\mathbf{6}+7)$ ratio highlights not only areas with hydrous silica minerals or jarosite, but also areas having spectral shapes with significant decreases in reflectance between ASTER bands 5 and 6-7 related to ironrich muscovites and (or) sericite + chlorite mixtures (fig. 1). However, such sericite-bearing areas will also be highlighted by the argillic-sericite-smectite index (band 6 absorption), whereas hydrous silica minerals will not, as band 6 absorption relative to adjacent bands, will be weak. Similarly, jarositic areas will always occur with ferric iron, unlike hydrous silica in most tuffaceous and (or) hydrothermally-altered rocks. The spectral confusion present in the individual index results is largely mitigated by examining pixel occurrence in multiple indices using Boolean algebra as presented below.
Based on examination of many scenes during the development of the automated technique, the hydrous silica-jarosite-sericite index is the least accurate of any of the indices, and results should be interpreted with caution. A majority of pixels identified as hydrous silica in sheet 5 are incorrect, and hydrous silica identified using the expert system-based analysis of the ASTER data (sheet 3) in a silicified breccias body near Red Mountain no. 3 was not identified using the automated technique.

\section{Ferrous Iron Index}

Ferrous iron produces a broad VNIR absorption at ASTER bands 2 and 3 relative to 1 and 4 (fig. 6). An ASTER $(\mathbf{1}+\mathbf{4}) /(\mathbf{2}+\mathbf{3})$ ratio is used to highlight areas in which this absorption is present. 

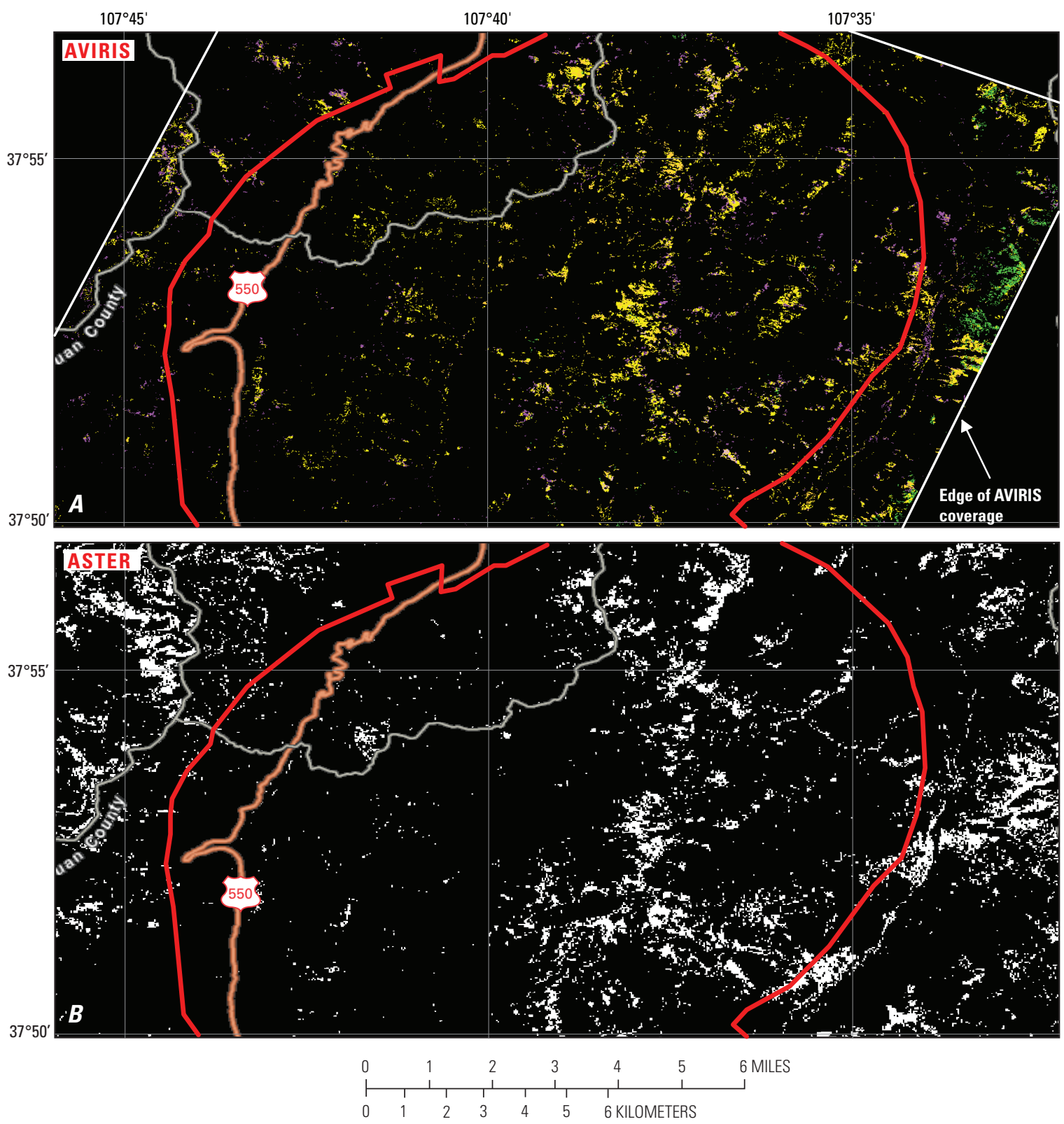

Figure 7. Comparison of ferrous iron-bearing minerals identified in the Silverton, Colo., area using $A$. expert system-based analysis of AVIRIS SWIR data (modified from Dalton and others, 2004), and B. the automated ferrous iron index. Approximate extent of Silverton caldera is indicated in red. Click on figure for more detailed image.

The results of the ferrous iron index correlate well with ferrous irons identified in the Silverton area using AVIRIS data (fig. 7). Such ferrous iron-bearing minerals correspond mainly with chlorite-bearing, propylitically altered rocks. The ferrous iron index has also been found to highlight some carbonate rocks in other areas. It is unknown if ferrous iron is present in these carbonates, or if the ferrous iron index is highlighting the rocks because of their bluishgray color. Ferrous iron is known to occur in recrystallized dolomitic marble (see http://speclab.cr.usgs.gov/spectral. lib06/ds231/descript/M/dolomite hs102.html) (Clark and others, 2007). The index can also be expected to highlight rocks having a general greenish color (for example, greenstones), and other areas with strong decreases in reflectance between the green (ASTER band 1) and red/near-infrared spectral regions (ASTER bands 2 and 3 ) such as blue-gray shales and moist soils.

\section{Green Vegetation Index}

An ASTER $(\mathbf{1}+\mathbf{3}) / \mathbf{2}$ ratio is used to highlight areas with strong absorption in the red wavelengths (ASTER band 2). Chlorophyll-related absorptions in green vegetation are the most common source of such absorption (fig. 2). 
Absorption in the red wavelengths has been observed on low-albedo surfaces in the arid Great Basin, including some underlain by young basalts, some of which have low-density grass and (or) sage cover. Such absorption is typically weak, and has been observed with ASTER and AVIRIS data. However, the vegetation may not be the only source of the band 2 absorption, which could be related to zeolite minerals or other greenish- or bluish-colored minerals or coatings on the basalts.

\section{Image Processing for Masking and Index Thresholding}

\section{Dark Area Masking}

As previously mentioned, ASTER SWIR data are unstable in areas of low surface albedo. Such areas are masked from analysis using thresholds of ASTER band 4 determined through examination of many scenes from different climates, land cover, and terrain relief. Different threshold values are used for semi-arid and temperate, alpine climates. Thresholds for additional climate and terrain relief types may be added as more scenes are analyzed. Based on the mean scaled radiance value of band 4, a band 4 threshold value is assigned and a mask created which highlights dark areas. This mask is then applied to all bands to remove data from dark areas.

\section{Water Masking}

An ASTER 1/4 ratio is used to highlight areas having a steep decrease in reflectance between the green and SWIR wavelengths. Water and snow are characterized by intense absorption in the SWIR relative to the visible spectral regions. A threshold value for the ratio was chosen based on examination of standing water in many ASTER scenes. A mask is created by applying the threshold to the $\mathbf{1} / \mathbf{4}$ ratio result. The mask is then applied to all bands to remove data from areas of snow and standing water. Turbid water, shallow water with a bright substrate, and mixtures of thin or melting snow and vegetation have reduced absorption in the SWIR and may not be entirely removed by this masking process.

\section{Selective Vegetation Suppression}

The argillic-sericite-smectite index is divided by the green vegetation index results to reduce the influence of green vegetation. This operation reduces false detections of clays and micas in highly vegetated areas. The operation is also performed on the carbonate-propylitic and dolomite-chloriteepidote indices in temperate and alpine areas having locally abundant vegetation. As in the dark area masking process described above, if the mean scaled radiance of band 4 is below an empirically-derived value, the scene is determined to be of the alpine and (or) temperate climate type, and the vegetation suppression operation is performed on the selected indices.

\section{Final Index Thresholding and Clipping}

The final indices (see file sanjuans_aster_autoalt54 pt-utm.img) are created by isolating the highest values using a common standard deviation threshold, followed by an indexspecific clip (removal) of the lowest index values based on extensive testing of scenes from a variety of climates, terrain relief, and alteration types. These clips are minor in scope, and were determined based on detailed comparisons of the index results to mineral maps created from spectroscopic analysis of ASTER and AVIRIS imagery. In arid and semi-arid climates, the low end of the green vegetation index is clipped to reduce influence of ASTER band 2 absorptions on lowalbedo surfaces not related to green vegetation. The amount of low-end index values which are removed increase in the following order from low to high: (1) argillic-sericite-smectite, (2) ferric iron and carbonate-propylitic, (3) dolomite-chloriteepidote, and (4) hydrous silica-jarosite-sericite and advanced argillic-kandite. The relatively high degrees of clipping of the latter two indices reflect a lower degree of confidence in the accuracies of results. The areal mixing of clay minerals and vegetation having ASTER band 5 absorption related to leaf biochemicals can result in false detections of minerals associated with advanced argillic alteration that also have absorption at band 5 (Rockwell, 2009; John and others, 2010). Absorptions at ASTER bands 6 and 7 related to hydrous silica minerals are typically shallow at the spatial and spectral scale of ASTER SWIR data, and false detections may occur that are caused in part by areal mixing of sericites or smectite (band 6 absorption) with certain types and densities of dry vegetation and (or) carbonate- or gibbsite-bearing rocks and soils (band 7 absorption). Increased clipping of low-end values will result in fewer detected pixels in an index, and increased confidence in those that remain. However, occurrences of the particular mineral group in lower abundance will be removed.

For example, alunite occurs in lower abundance in alluvium derived from an advanced argillic alteration zone than in the zone itself, and much of that alluvium can be removed by higher clipping values. Clipping values were determined through testing in well-known altered areas including the Goldfield mining district in Nevada, the site of extensive alunite- and pyrophyllite-bearing alteration and derived alluvium (fig. 8). Resultant clipping values for the advanced argillic-kandite index remove most alunite-bearing alluvium, andhighlights the altered areas themselves. Such tradeoffs between completeness and accuracy of results are required for regional- and national-scale mapping using automated, ratiobased techniques with ASTER data. 


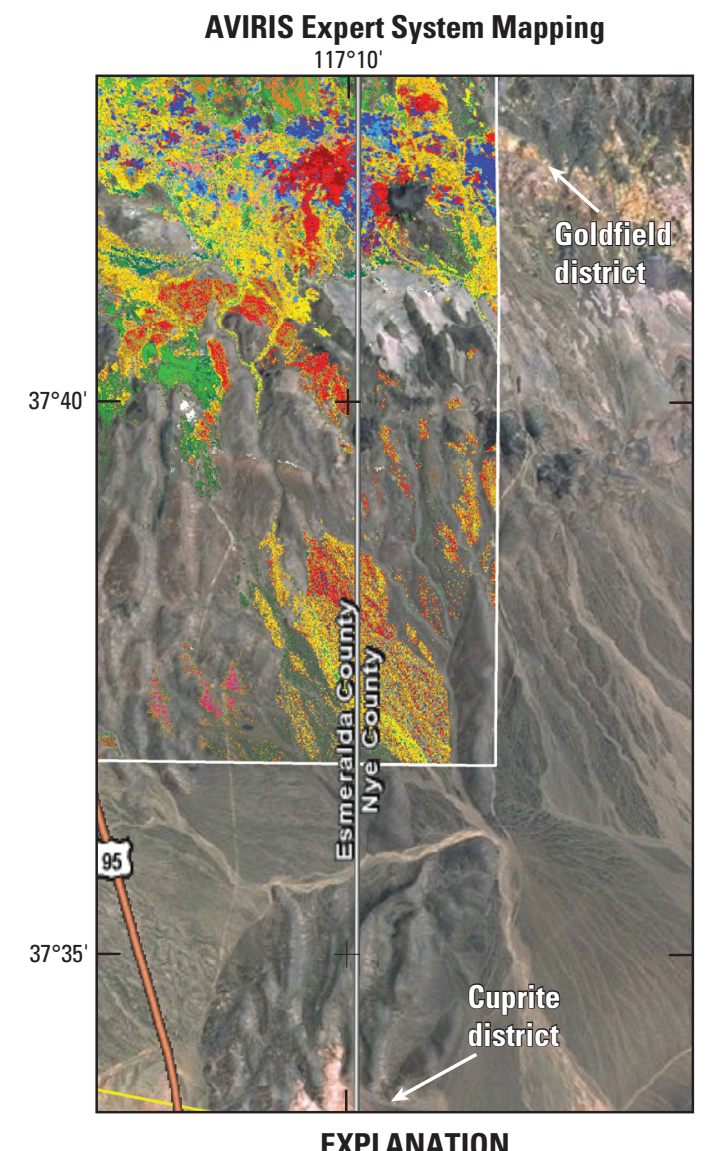

EXPLANATION

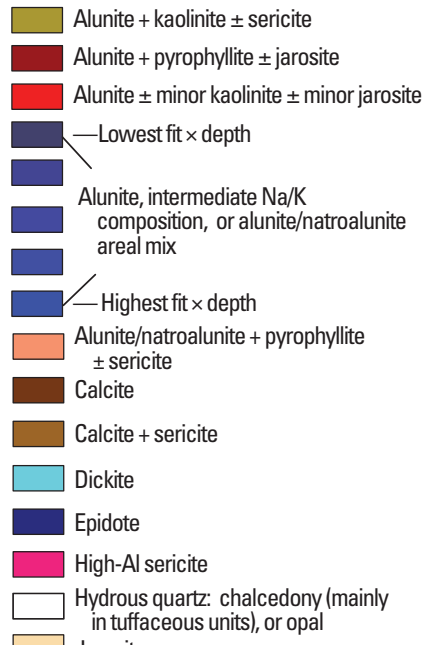

$\square$ Kaolinite + pyrophyllite

Kaolinite \pm smectite

Kaolinite $75 \%$ + alunite $25 \%$ areal mix

$\square$ Kaolinite and(or) halloysite

mixture

tite (montmorillonite)

Natroalunite

Natroalunite + kaolinite

Natroalunite \pm dickite, other clays

Pyrophyllite

Pyrophyllite + sericite

Sericite \pm kaolinite 1-Lowest fit $\times$ depth

Sericite \pm kaolinite 2

Sericite \pm kaolinite 3

Sericite \pm kaolinite 4

Sericite \pm kaolinite 5-Highest fit $\times$ depth in tuffaceous units), or opal

Jarosite
Low-Al sericite or muscovite + chlorite

ASTER Expert System Mapping
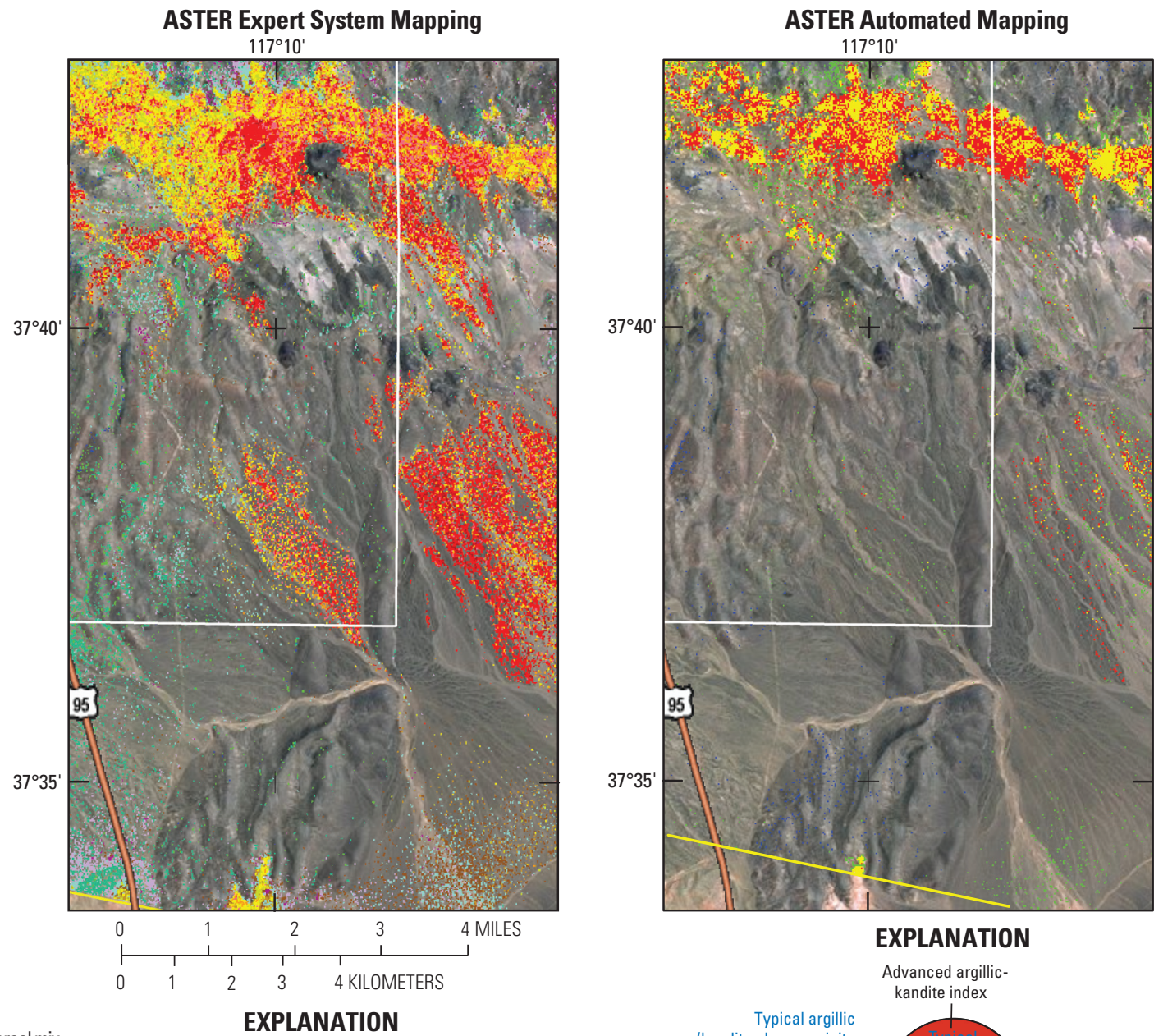

EXPLANATION

Advanced argillic-

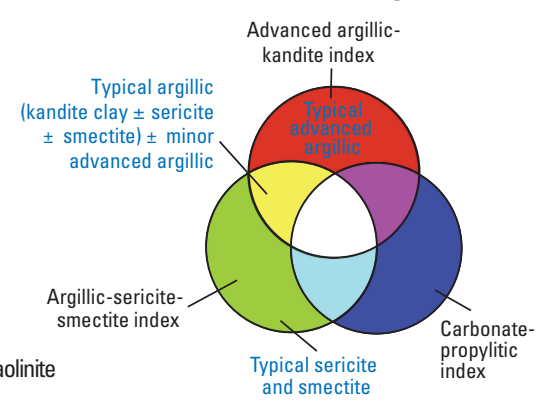

$\square$ Al sericite ( \pm kaolinite

Alunite ( \pm pyrophyllite)

$\square$ Alunite + kaolinite

$\square$ Calcite

Calcite (or chlorite/epidote)
+ sericite (or smectite)

Chlorite (Mg-OH SWIR

ferrous/ferric iron absorptio

Dolomite

Epidote, or calcite + dolomite

mixture

e/Mg sericite or muscovite +

chlorite mixture

$\square$ Gypsum \pm clay minerals

Jarosite \pm gypsum, or ferric iron +opal/chalcedony

Kaolinite \pm sericite

$\square$ Kaolinite \pm smectite

Kaolinite and (or) dickite/nacrite

Natroalunite, or alunite + minor kaolinite

Opal and (or) chalcedony

Pyrophyllite or alunite Smectite (montmorillonite)
or low-abundance sericite

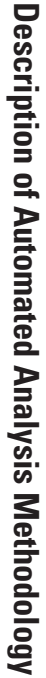


Figure 8 (previous page). Comparison of mineral maps of the area between the Goldfield and Cuprite mining districts, western Nevada, produced from AVIRIS and ASTER data. Zones of magmatic-hydrothermal, advanced argillic alteration in the southern and southwestern parts of the Goldfield district occur in an east-west belt along the top of the maps. Alunite- and kaolinitebearing alluvium derived from these zones has been transported southeastwards by fluvial processes toward Stonewall Flat. The northern tip of the Cuprite eastern center is visible at center bottom. The map on the left was produced using expert systembased spectroscopic analysis (Rockwell and others, 2005; 2006) of 1998 AVIRIS data. Alunites of varying composition are shown in red and blue. The map at center was produced using expert systembased spectroscopic analysis (Rockwell, 2009) of 2001 ASTER data. Alunite-bearing rocks are shown in red and orange, kandite clay minerals (mainly kaolinite) in yellow. The map at right was produced from orthocorrected (AST140TH) data of the same 2001 ASTER scene using the automated, ratio-based analysis described herein. The advanced argillic-kandite, argillic-sericite-smectite, and carbonate-propylitic indices are shown as red, green, and blue, respectively. Pixels that occur in both the advanced argillickandite and argillic-sericite-smectite indices are shown in yellow (red + green additive color mixing), and correspond to argillic alteration. Note how most of the alunite-bearing alluvium in the center of the maps at left is not shown in the map at right. If clipping values were optimized for the Goldfield area alone, the areal extent of alunite-bearing alluvium would be comparable to those in the maps at left. White and yellow lines indicate the limits of the AVIRIS and ASTER data coverages, respectively. In the explanation for the ASTER-based automated mapping at lower right, black text indicates which indices are assigned red, green, and blue. Blue text indicates typical mineralogic compositions for selected colors in the map relating to argillic minerals. Click on figure for more detailed image.

\section{Modeling of Hydrothermal Alteration Type and Mineral Groups through Boolean Combination of Index Results}

For the purposes of (1) combining the nine indices into a more easily-visualized single map, (2) assigning GISready descriptive attributes to the map, (3) applying geologic knowledge of the alteration types and mineral groups identified by the indices, and (4) mitigating the mixing of mineral groups in single indices as discussed above, Boolean algebra is used to examine pixel occurrence in one or more indices and generate 23 output classes of alteration type, mineral groups, and green vegetation (sheet 5). Table 2 shows the logic of the algebraic expressions.
The modeling of the index results into output mineral groups does not account for all possible combinations of pixel occurrence in multiple indices, and the raw index results themselves can be consulted to obtain information on additional mineral assemblages. For example, the co-occurrence of the sericite and (or) smectite mineral group with the ferrous iron mineral group is not modeled. Most mineral groups applicable to hydrothermal alteration characterization and lithologic discrimination that are identifiable using ASTER data have been defined in the modeling logic.

The logic used to generate the "jarosite \pm sericite \pm smectite, or hydrous silica + ferric iron" output class (\#8) is different than that used for other classes because most jarosites occur as coatings on a variety of rock and rock-alteration types. The logic states that the class will be mapped as long as a pixel is highlighted by both ferric iron indices and the hydrous silica-jarosite-sericite index, regardless of its occurrence in other indices. Figure 9 shows that the class generally correlates generally well with a jarosite + sericite mixture directly identified using AVIRIS data (Dalton and others, 2004), although significantly fewer occurrences of the mixture were detected using the ASTER data. Jarosite derived from the subaerial oxidation of pyrite commonly occurs as coatings on a supergene overprint of kaolinite \pm smectite, and this overprint typically obscures the $\mathrm{Fe}-\mathrm{OH}$ absorption of jarosite near $2.27 \mu \mathrm{m}$ but not ferric iron absorptions in the VNIR (Rockwell and others, 2005). Therefore, most jarosite will be highlighted by one or both of the ferric iron indices, and only the most abundant, clay-free occurrences will be identified in the modeled "jarosite \pm sericite \pm smectite, or hydrous silica + ferric iron" output class.

Class 11 (table 2) is named "argillic + ferric iron or weathered phyllic" and may include (1) argillic alteration with ferric iron (for example, hypogene kaolinite + hematite, or hypogene kaolinite + supergene jarosite derived from pyrite oxidation) and (2) weathered phyllic alteration with a supergene argillic overprint. Class 12 is named "sericite and (or) smectite + ferric iron (may include fresh phyllic)" and may include (1) "fresh" phyllic alteration without a supergene argillic overprint (caused by either recent exposure or low pyrite content), (2) iron- and smectite-bearing playa surfaces, and (3) sericite with a coating of ferric iron derived from weathering of mafic, iron-bearing minerals.

In carbonate and propylitically-altered rocks, the inclusion of logic to isolate band 7 absorptions associated with dolomite, chlorite, and epidote, and the modeling of the "carbonate-propylitic + ferrous iron" output class which will likely correspond to chlorite, and (or) epidote, result in increased likelihood that pixels within the "carbonatepropylitic" output class correspond to calcite, which, when pure, has nearly no band 7 absorption (fig. 5). 
Table 2. Boolean logic used to combine index results into a single, classified map (see sheet 5). Blank cells represent NOT operators. The ASTER band(s) in which the indices detect absorption relative to adjacent bands are indicated in the first row.

\begin{tabular}{|c|c|c|c|c|c|c|c|c|c|c|}
\hline \multirow{2}{*}{$\begin{array}{l}\text { Output } \\
\text { Class \# }\end{array}$} & \multirow[t]{2}{*}{ Band Absorption } & Ferric iron 1 & Ferric iron 2 & $\begin{array}{c}\text { Advanced argillic- } \\
\text { kandite }\end{array}$ & $\begin{array}{l}\text { Argillic-sericite- } \\
\text { smectite }\end{array}$ & $\begin{array}{l}\text { Carbonate- } \\
\text { propylitic }\end{array}$ & $\begin{array}{c}\text { Dolomite-chlorite- } \\
\text { epidote }\end{array}$ & $\begin{array}{l}\text { Hydrous silica- } \\
\text { jarosite-sericite }\end{array}$ & Ferrous iron & $\begin{array}{c}\text { Green } \\
\text { vegetation }\end{array}$ \\
\hline & & 1 & 1 and 3 & 5 & 6 & 7 and 8 & 7 and (7 and 8) & 6 and 7 & 2 and 3 & 2 \\
\hline 1 & minor ferric iron & $\mathrm{X}$ & & & & & & & EXCLUDED & \\
\hline 2 & major ferric iron & & $\mathrm{x}$ & & & & & & EXCLUDED & \\
\hline 3 & advanced argillic ( \pm ferric iron) & AND/OR/NOT & AND/OR/NOT & AND & & & & & EXCLUDED & \\
\hline 4 & $\begin{array}{l}\text { argillic (kandite clay } \pm \text { sericite } \pm \\
\text { smectite) }\end{array}$ & & & AND & AND & & & & EXCLUDED & \\
\hline 5 & sericite and (or) smectite & & & & $\mathrm{x}$ & & & & EXCLUDED & \\
\hline 6 & carbonate - propylitic & & & & & AND & & & & AND/NOT \\
\hline 7 & dolomite & & & & & AND & AND & AND/NOT & & AND/NOT \\
\hline 8 & $\begin{array}{l}\text { jarosite } \pm \text { sericite } \pm \text { smectite, or } \\
\text { hydrous silica }+ \text { ferric iron }\end{array}$ & AND & AND & AND/NOT & AND/NOT & AND/NOT & AND/NOT & AND & EXCLUDED & AND/NOT \\
\hline 9 & hydrous silica & & & & & & & $\mathrm{X}$ & EXCLUDED & \\
\hline 10 & $\begin{array}{l}\text { sericite + chlorite or } \mathrm{Fe} / \mathrm{Mg} \\
\text { sericite }\end{array}$ & & & & AND & & & AND & EXCLUDED & \\
\hline 11 & $\begin{array}{l}\text { argillic }+ \text { ferric iron or weathered } \\
\text { phyllic }\end{array}$ & $\mathrm{AND} / \mathrm{OR}$ & $\mathrm{AND} / \mathrm{OR}$ & AND & AND & & & & EXCLUDED & \\
\hline 12 & $\begin{array}{l}\text { sericite and (or) smectite }+ \text { ferric } \\
\text { iron (may include fresh phyllic) }\end{array}$ & $\mathrm{AND} / \mathrm{OR}$ & $\mathrm{AND} / \mathrm{OR}$ & & AND & & & & EXCLUDED & \\
\hline 13 & $\begin{array}{l}\text { carbonate - propylitic }+ \text { sericite } \\
\text { and (or) smectite }\end{array}$ & & & & AND & AND & & & EXCLUDED & \\
\hline 14 & green vegetation & & & & & & & & EXCLUDED & $\mathrm{x}$ \\
\hline 15 & carbonate - propylitic + ferric iron & AND/OR & AND/OR & & & AND & & & EXCLUDED & \\
\hline 16 & $\begin{array}{l}\text { sericite + chlorite or } \mathrm{Fe} / \mathrm{Mg} \\
\text { ericite + ferric iron }\end{array}$ & $\mathrm{AND} / \mathrm{OR}$ & $\mathrm{AND} / \mathrm{OR}$ & & AND & & & AND & EXCLUDED & \\
\hline 17 & $\begin{array}{l}\text { carbonate - propylitic }+ \text { sericite } \\
\text { and (or) smectite }+ \text { ferric iron }\end{array}$ & $\mathrm{AND} / \mathrm{OR}$ & $\mathrm{AND} / \mathrm{OR}$ & & AND & AND & $\mathrm{AND} / \mathrm{NOT}$ & & EXCLUDED & \\
\hline 18 & dolomite + ferric iron & $\mathrm{AND} / \mathrm{OR}$ & $\mathrm{AND} / \mathrm{OR}$ & & & AND & AND & AND/NOT & EXCLUDED & AND/NOT \\
\hline 19 & $\begin{array}{l}\text { carbonate - propylitic } \pm \text { hydrous } \\
\text { silica }\end{array}$ & & & & & AND & & AND & EXCLUDED & \\
\hline 20 & $\begin{array}{l}\text { carbonate - propylitic } \pm \text { hydrous } \\
\text { silica }+ \text { ferric iron }\end{array}$ & AND/OR & $\mathrm{AND} / \mathrm{OR}$ & & & AND & & AND & EXCLUDED & \\
\hline 21 & ferrous iron & & & & & & & & $\mathrm{X}$ & \\
\hline 22 & $\begin{array}{l}\text { carbonate - propylitic }+ \text { ferrous } \\
\text { iron }\end{array}$ & & & & & AND & & & AND & AND/NOT \\
\hline 23 & dolomite + ferrous iron & & & & & AND & AND & AND/NOT & AND & AND/NOT \\
\hline
\end{tabular}



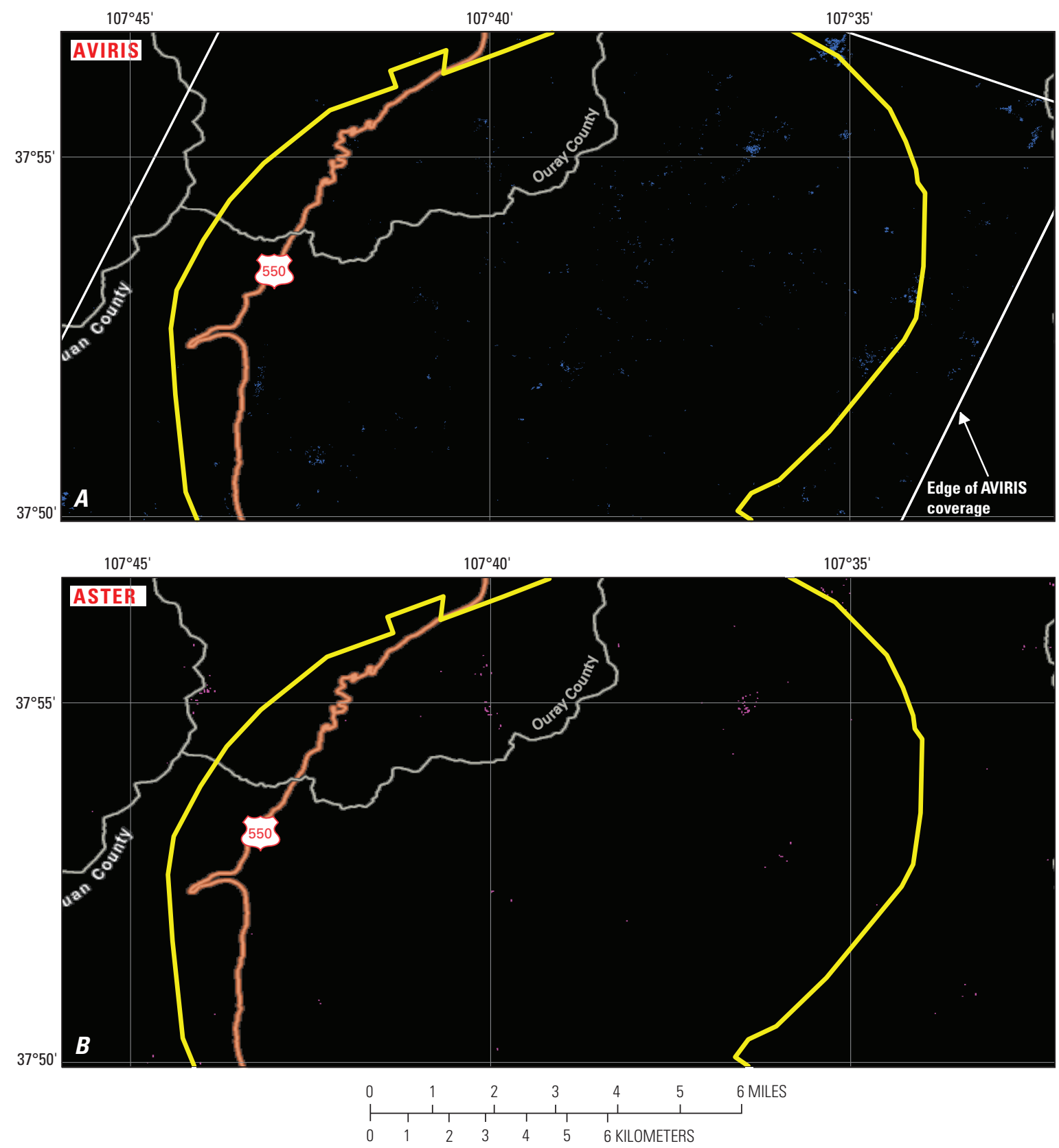

Figure 9. Comparison of occurences of jarosite + sericite detected in the Silverton caldera in Colorado using $A$. expert system-based analysis of AVIRIS SWIR data (modified from Dalton and others, 2004), and $B$. the automated modeling of the ASTER-derived mineral group indices (output class no. 8 described in table 2). Approximate extent of Silverton caldera is indicated in yellow. Click on figure for more detailed image. 


\section{Comparison and Validation of Automated Results}

As a means of validating the results of the automated analysis methodology, derived maps of material groups are compared with those generated from detailed spectroscopic analysis of AVIRIS and (or) ASTER data .These data cover the Silverton caldera in Colorado, the Antelope Range in the Marysvale volcanic field in south-central Utah, the Goldfield and Cuprite mining districts in Nevada, and the Wah Wah Mountains in southwestern Utah, the site of the concealed Pine Grove porphyry molybdenum deposit, the NG alunite deposit, and other Miocene epithermal systems.

\section{Silverton Caldera, San Juan Mountains, Colorado}

Mineral mapping results derived from analysis of AVIRIS and ASTER data over the Silverton caldera are shown in figure 10. The map at top shows selected alteration types produced by combining mineral assemblages identified by spectroscopic analysis of AVIRIS data (Dalton and others, 2004). All spectrally pure alunites and pyrophyllite were combined into the advanced argillic alteration class (red), and all kaolinite- and dickite-dominant assemblages were combined into the argillic \pm sericite class (yellow). Directly-identified mixtures of alunite or phyrophyllite + kaolinite have been colored orange, and represent smaller or more weakly altered advanced argillic zones. Polygons showing phyllically-altered rocks produced by interpretation of the AVIRIS-derived maps and field mapping (Bove and others, 2007) are overlain in cyan. The map at bottom shows selected results from the automated analysis of ASTER data (sheet 5). The two maps are not entirely equivalent in that the ASTER-derived map incorporates ferric iron identifications, and the AVIRISderived map does not.

Most altered areas identified using AVIRIS data were also identified using the automated ASTER analysis methodology. The spectroscopic analysis of ASTER data (sheet 3) mapped and characterized these areas with significantly greater accuracy and detail than the automated analysis, as expected. In the automated ASTER mapping results, much of the advanced argillic alteration (alunites and pyrophyllite) in the Red Mountain area near the top center of the maps is included in the "argillic + ferric iron or weathered phyllic \pm minor advanced argillic" class rather than the advanced argillic class, although the east-west belt of the most pervasive alteration is discernable (red pixels). Advanced argillic pixels (red) that occur along the edges of the altered areas in some cases most likely represent areal mixtures of kandite clay + dry vegetation (Rockwell, 2009).

Comparison of sheets 3 and 4 with the maps shown in figure 10 indicates that both the spectroscopic and automated analysis of ASTER data identified less advanced argillic alteration in the northern part of the Red Mountain no. 1 area than did the analysis of AVIRIS data. In this area, a small zone of mixed-composition Na-K alunite $100 \mathrm{~m} \times 50 \mathrm{~m}$ in size occurs near the ridgeline, surrounded by a $141-\mathrm{m}$ diameter zone of alunite + kaolinite. Float and colluvium consisting of minor alunite and kaolinite derived from the small central advanced argillic zone account for much of the alunite-bearing rock in the area. The majority of alteration in the area is argillic or phyllic in nature (kandite clay + ferric iron \pm sericite \pm smectite). The abundance of alunite in this area is too low to be detected using ASTER SWIR data having a ground resolution of $30 \mathrm{~m}$.

The AVIRIS-derived map in figure $10 \mathrm{~A}$ shows that most phyllic alteration has a mixed kaolinite (yellow) and sericite (purple) surface signature (with abundant goethite and (or) jarosite which are not shown). Kaolinite, in most cases of supergene origin, is present in nearly all phyllic alteration, although in varying amounts. Some phyllic alteration is primarily kaolinitic. A vast majority of the exposed sericite in the Silverton caldera is either lithologic or related to lowgrade regional propylitic alteration where it often occurs with chlorite. Therefore, the presence of sericitic signatures alone cannot be used as an accurate proxy for phyllic alteration.

A discrepancy in alteration characterization between the results of the automated ASTER data analysis and those generated by spectroscopic analysis of the AVIRIS and ASTER data is shown in figure 10 . The area marked "A" in figure 10 is located on an east-west-trending ridge $1.3 \mathrm{~km}$ east-southeast of the alteration center at Red Mountain no. 3. AVIRISbased mapping identifies this area primarily as pyrophyllite with local zones of pyrophyllite + kaolinite and alunite + pyrophyllite (Dalton and others, 2004). These highly altered zones grade outwards to the east and west to pyrophyllite + sericite and (or) kaolinite with local zones of kaolinite + sericite. The AVIRIS-based mapping also identified goethite with local, northeast-trending jarositic zones, indicating abundant pyrite. A majority of the pyrophyllite-bearing rocks in this area are colluvium derived from small outcrops near the ridgeline. The ASTER-based spectroscopic mapping (sheet 3) identifies this area as primarily alunite with local pyrophyllite and kaolinite grading outwards to alunite + kaolinite and then kaolinite + sericite. The low spectral and spatial resolution of ASTER SWIR data make it difficult to accurately differentiate alunite and pyrophyllite, which can occur as intimate and areal mixtures in magmatic-hydrothermal alteration systems (Rockwell, 2009). Abundant ferric iron was also identified (sheet 2). The automated ASTER-based mapping (sheet 5, and fig. 10B) identified this area as the "sericite and (or) smectite + ferric iron (may include fresh phyllic)" class, indicating that the area was not detected by the advanced argillic-kandite index (table 2). Even if the clipping value for the advanced argillic-kandite index is set lower, the area is not identified as advanced argillic alteration. 


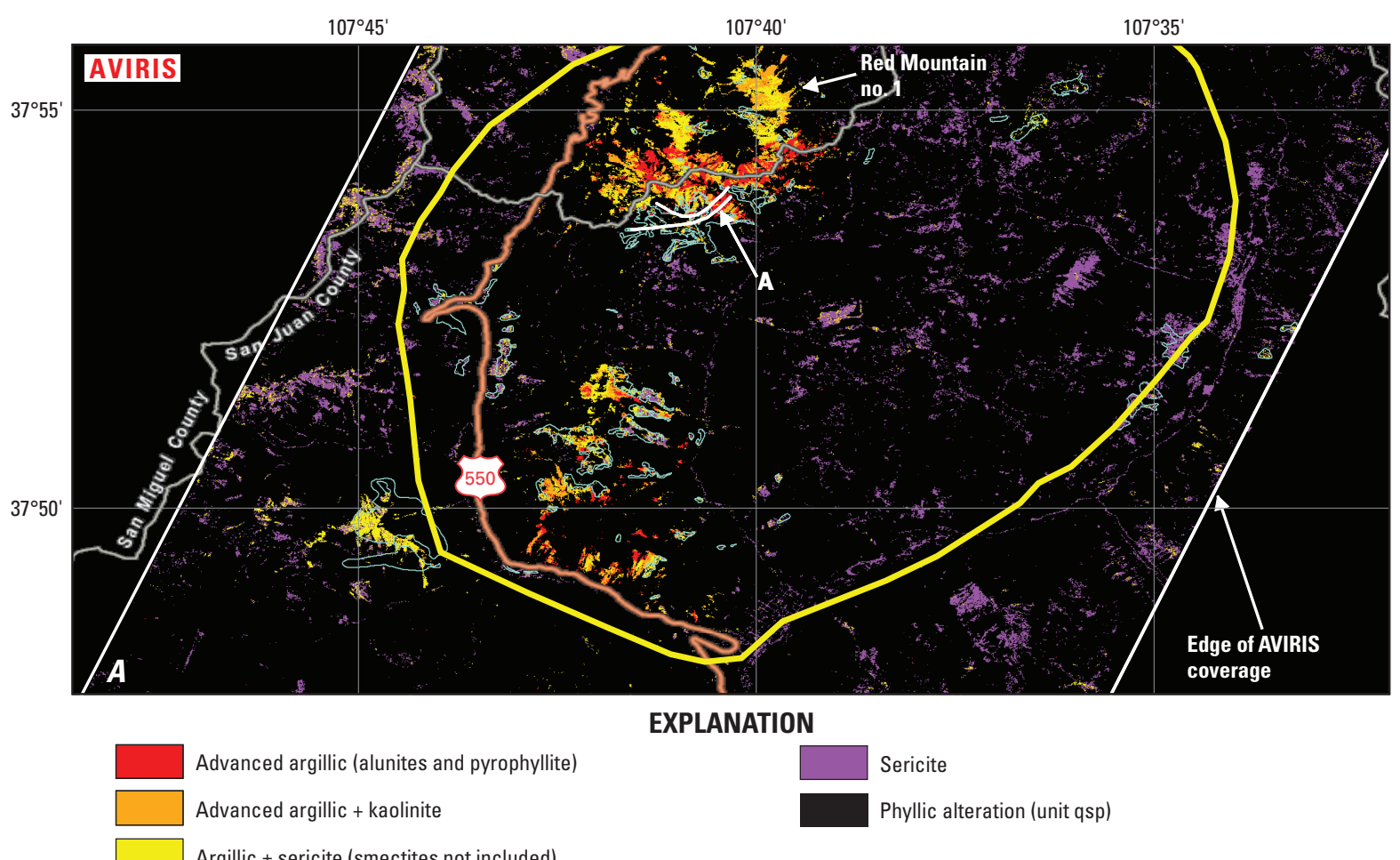

Argillic \pm sericite (smectites not included)

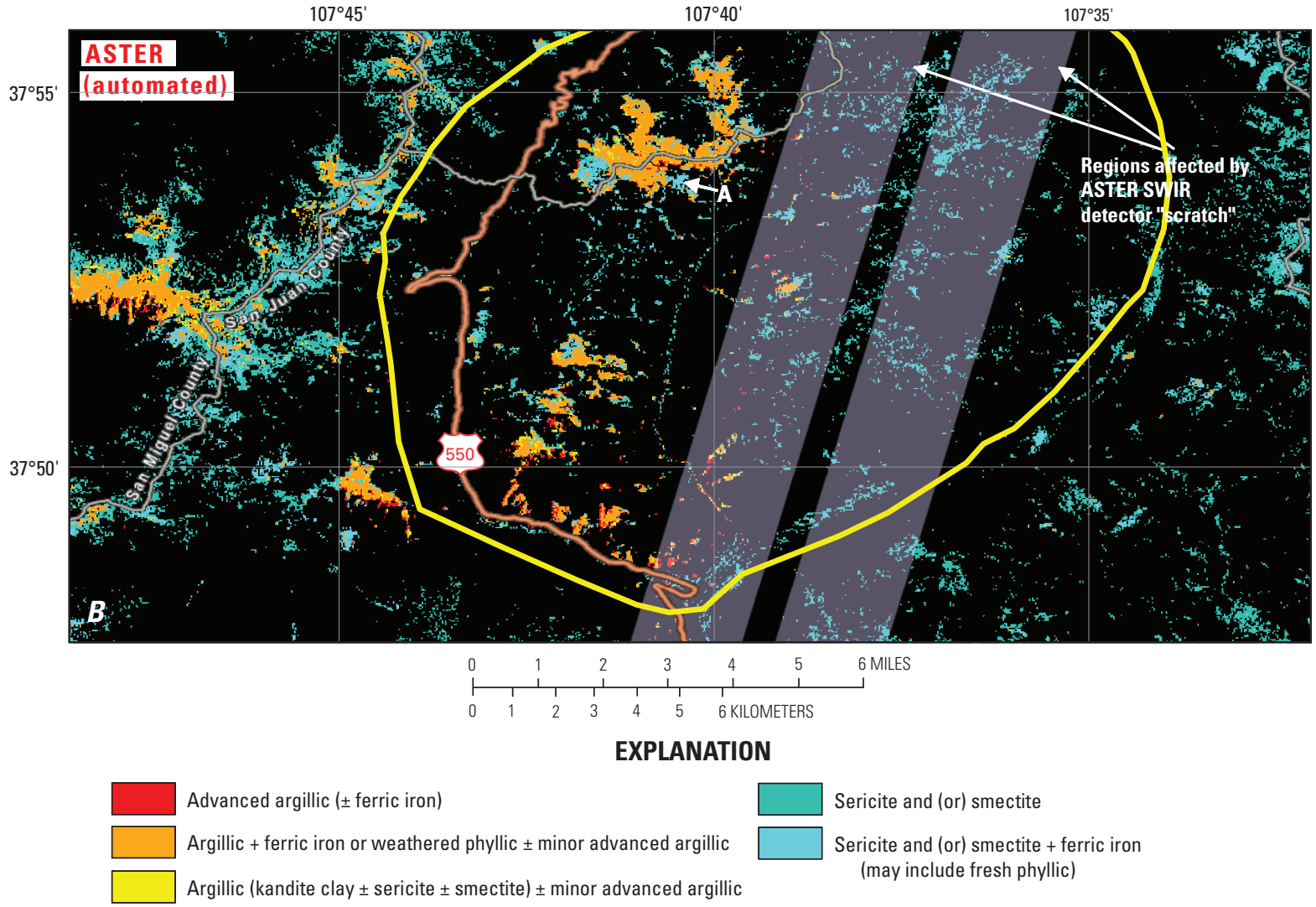


Figure 10 (previous page). Comparison of advanced argillic, argillic, and phyllic alteration in the Silverton caldera in Colorado identified and mapped using $A$. expert system-based analysis of AVIRIS data (modified from Dalton and others, 2004), and $B$. the automated analysis of ASTER data (results modified from sheet 5 ). Cyan polygons in $A$ are the primary phyllic alteration unit mapped by Bove and others (2007). These polygons do not show the full extent of phyllic alteration, as much is combined into other mixed alteration units (for example, qsp-wsp, wsp, wsp-hyd, wsp-pr) which are not shown ("qsp" refers to quartz-sericite-pyrite, or phyllic, alteration). Note false detections of advanced argillic alteration within the area of degraded SWIR data associated with the ASTER detector "scratch" (Rockwell, 2009). Approximate extent of Silverton caldera is indicated in yellow. Click on figure for more detailed image.

ASTER reflectance spectra of this area indicate that the band 5 absorption features associated with alunite and pyrophyllite have a continuum-removed band depth of 6-9 percent, and kaolinite \pm sericite spectra have a band 6 feature depth of 4 percent. Spectra from the intense quartz-alunite alteration on the flanks of Red Mountain no. 3 to the west (where advanced argillic alteration was detected using the automated mapping) have typical band 5 absorption depths of $17-18$ percent, indicating significantly greater alunite abundance given a constant grain size. It is therefore assumed that the advanced argillickandite index will not detect pixels in which band 5 absorption is less than approximately $10-15$ percent.

A narrow zone of alunite + pyrophyllite, a signature assemblage for magmatic-hydrothermal advanced argillic alteration, occurs along an arcuate, or ring, fracture system that crosses area "A" (northern white line in AVIRIS-derived map in figure 10). Alunite-free pyrophyllite occurs along another, sub-parallel fracture system immediately to the south that extends south and west through intense phyllic alteration situated immediately adjacent to and beneath area " $A$ " along Prospect Gulch. Vertical fracture zones and localized, pipelike structures of pyrophyllite \pm illite, with natroalunite and (or) dickite \pm alumino-phosphate sulfate minerals at higher levels, have been recognized within phyllic alteration situated beneath or adjacent to the Big Rock Candy Mountain (BRCM) and Big Star alunite deposits of the Marysvale volcanic field (Rockwell and others, 2005; 2006, Cunningham and others, 2005). Pyrophyllite replaces sericite at the margins of quartzalunite centers upon outward transition to phyllic alteration in the lower part of the relict hydrothermal systems at Red Mountain no. 3 (Bove and others, 2007). The relatively low abundance of advanced argillic minerals in area "A," the prevalence of pyrophyllite over alunite, abundant pyrite, close proximity to mapped phyllic alteration, and the presence of sericite in its peripheral zones suggest that the area represents transitional advanced argillic-phyllic alteration. Such a mixed alteration type (qap-s) was mapped immediately adjacent to area " $\mathrm{A}$ " to the east and north, where sericite has been replaced by pyrophyllite. The identification of this area as "sericite and (or) smectite + ferric iron (may include fresh phyllic)" by the automated ASTER mapping associates it mineralogically with the phyllic alteration in Prospect Gulch rather than the quartz + alunite \pm pyrophyllite \pm kaolinite of the main advanced argillic centers in the area.

\section{Antelope Range, Marysvale Volcanic Field, Utah}

Figure 11 shows ASTER-derived maps of the replacement alunite deposits in the Antelope Range area of the Marysvale volcanic field in south-central Utah (Rockwell and others, 2005; 2006). The map produced by spectroscopic analysis (fig. 11A, Rockwell, 2009) shows high correlation with the map produced by the automated analysis (fig $11 B$ ). The primary difference between the two maps is the more extensive occurrence of sericite and (or) smectite (cyan colors) shown in latter map. Sericite and smectite having low fit $\times$ depth of diagnostic absorption features identified using spectroscopic techniques were removed from figure $11 \mathrm{~A}$ to enhance accuracy and simplicity of the results. Mineral detections with low fit $\times$ depth values correspond to lower mineral abundance (reduced feature depth) and (or) lower degrees of least-squares fit (and thus confidence) to reference spectra. Such detections are often removed from mineral maps to reduce complexity and show only results with high confidence. Also note that sericite and smectite are not differentiated by the automated analysis.

In addition, the map produced using the automated analysis shows less extensive calcite-chlorite-epidote-bearing propylitic alteration in the Hoover pluton and other monzonites of the Central Intrusion located 1-8 km east of BRCM than do the results of the spectroscopic analysis. This effect is caused by the dark area masking performed during the automated analysis which removed the darkest (lowest band 4 radiance values) prior to analysis. The propylitically-altered intrusive rocks generally have low surface albedo.

Note that the phyllically-altered dacite lava flows on the eastern and northeastern flanks of BRCM were mapped as the "argillic + ferric iron or weathered phyllic \pm minor advanced argillic" class (orange), and not as a sericite-bearing class. The supergene overprint on these highly pyritic and illitic rocks (with local vertical zones of pyrophyllite) is well developed and consists of natrojarosite, gypsum (fig. 11A), kaolinite, smectite, and local copiapite and epsomite (Cunningham and others, 2005; Rockwell and others, 2005). 


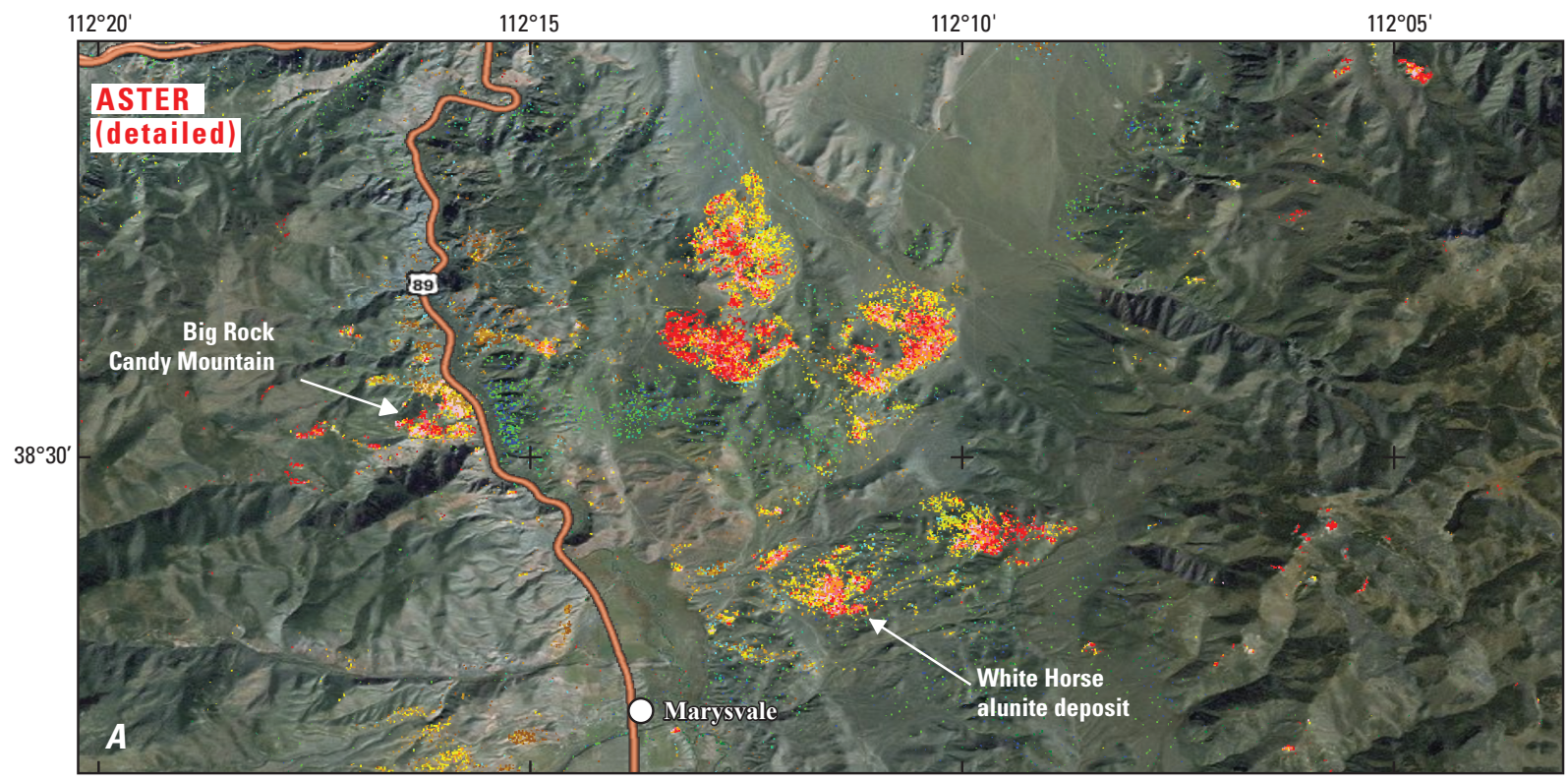

\begin{tabular}{|c|c|c|}
\hline & EXPLANATION & \\
\hline Al sericite & Dolomite & $\begin{array}{l}\text { Jarosite, or hydrous quartz + ferric iron } \\
\text { near mapped hydrous quartz }\end{array}$ \\
\hline Alunite & Epidote, or calcite + dolomite mix & Kaolinite + sericite \\
\hline Alunite + kaolinite & $\mathrm{Fe} / \mathrm{Mg}$ sericite, or mixture of muscovite & Kaolinite + smectite \\
\hline Calcite & Smectite (montmorillonite) & Kandite clay \\
\hline Calcite + sericite or smectite & Gypsum & Natroalunite, or alunite + minor kaolinite \\
\hline Chlorite & Hydrous quartz-0pal and (or) chalcedony & Pyrophyllite and (or) alunite \\
\hline
\end{tabular}

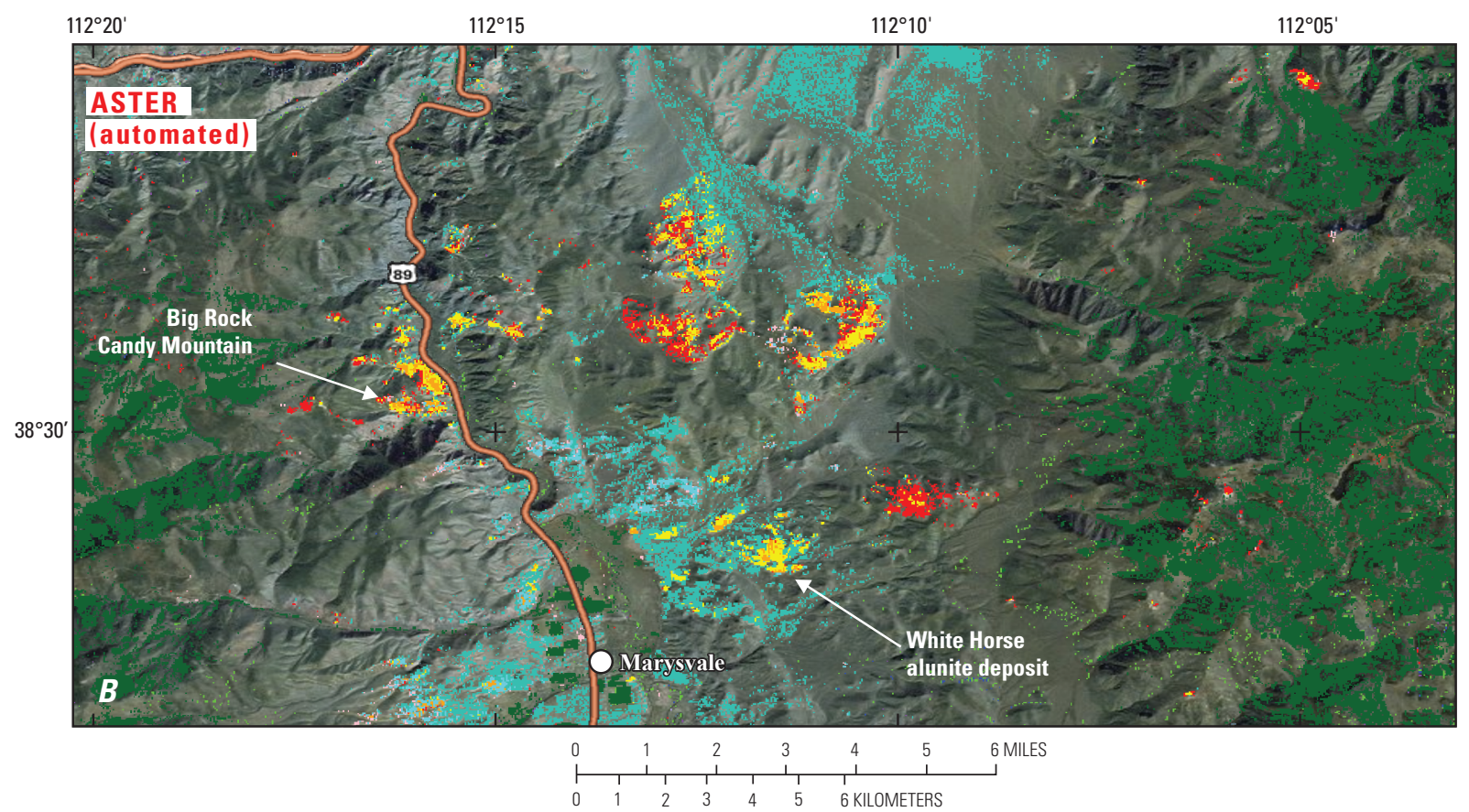

Figure 11. Mineral maps of the Antelope Range area of the Marysvale volcanic field, Utah. A. Results of detailed, expert system-based spectroscopic analysis of ASTER data (Rockwell, 2009). See sheet 5 for color explanation. $B$. Results of automated, ratio-based methodology described herein (see sheet 5 for color explanation). Click on figure for more detailed image. 


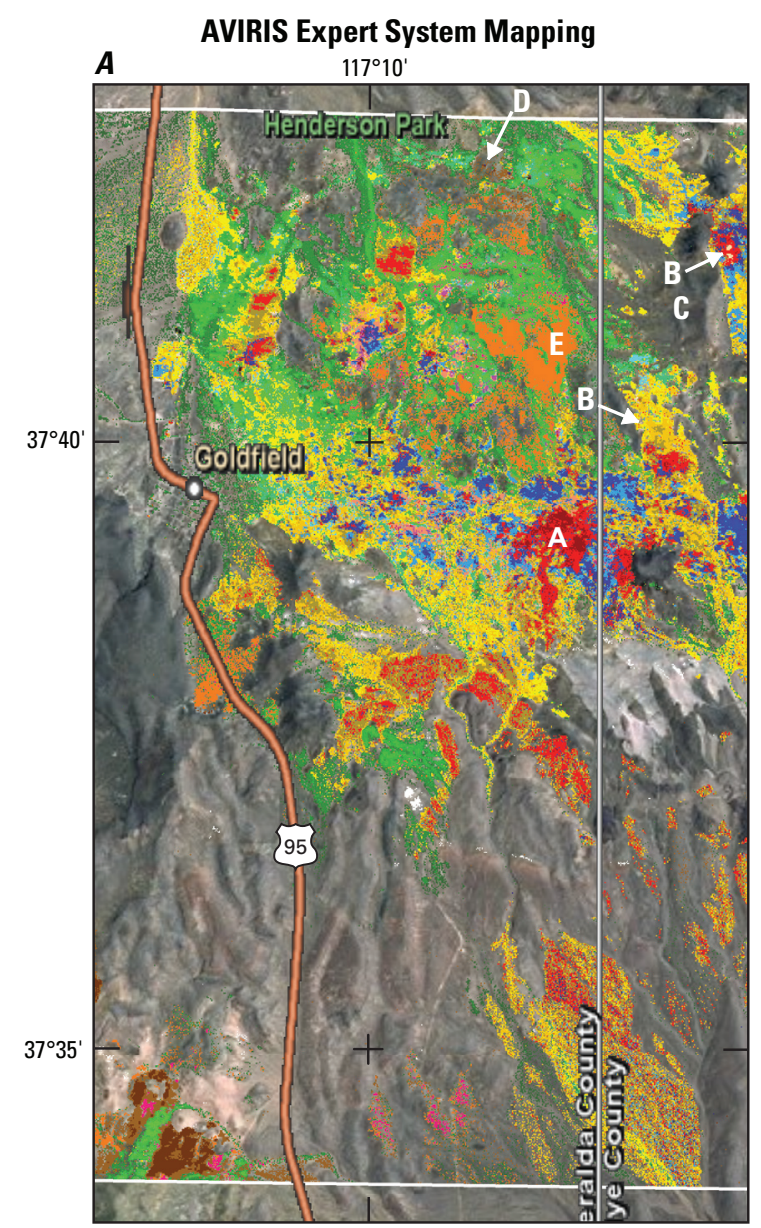

EXPLANATION $\boldsymbol{A}$

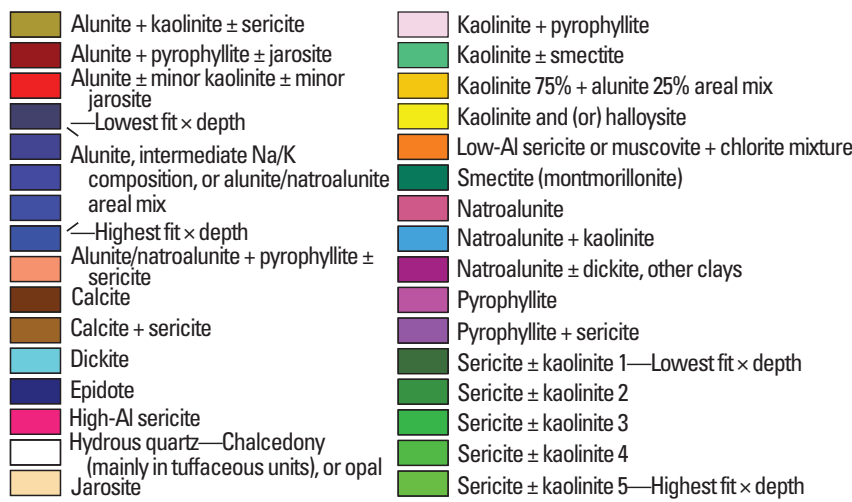

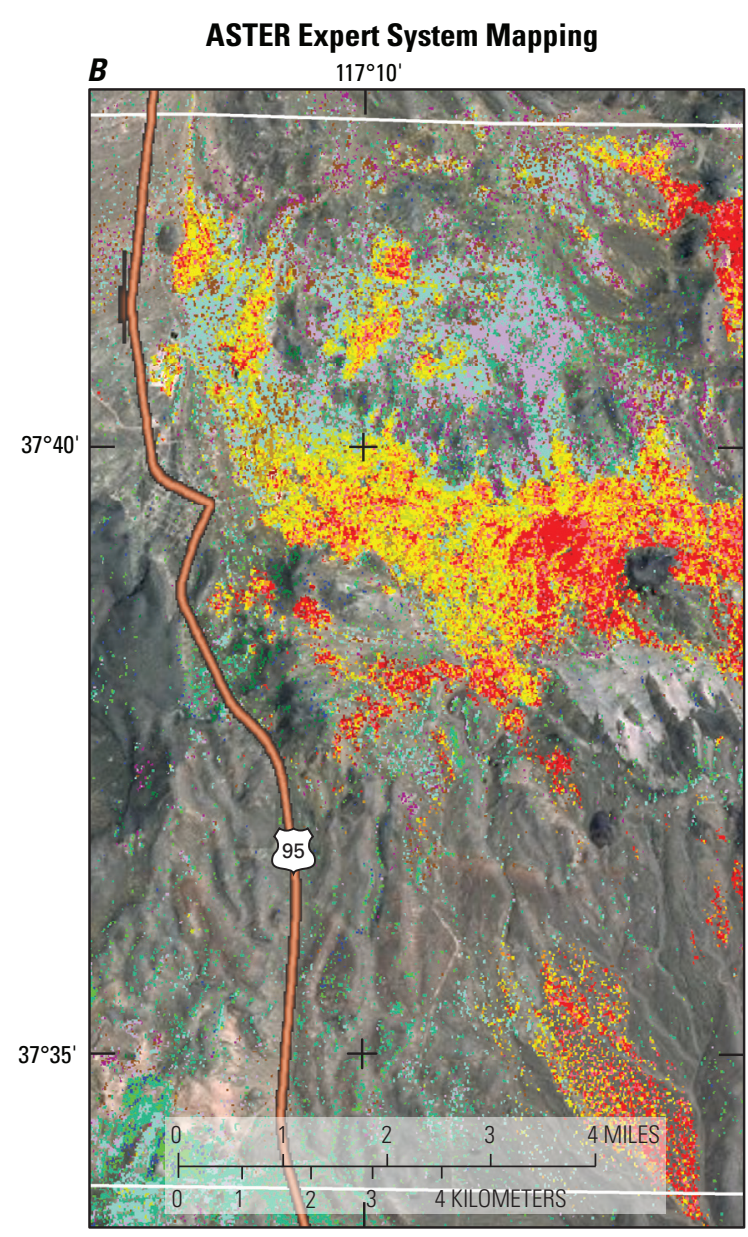

EXPLANATION $B$

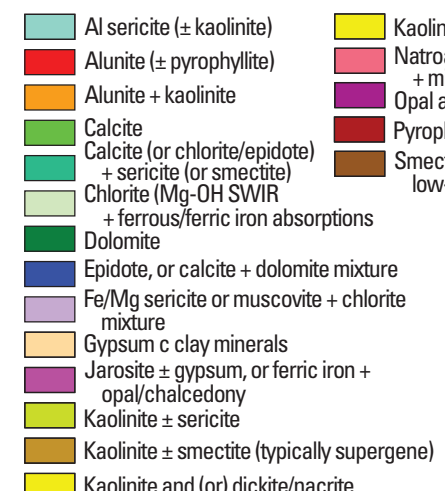

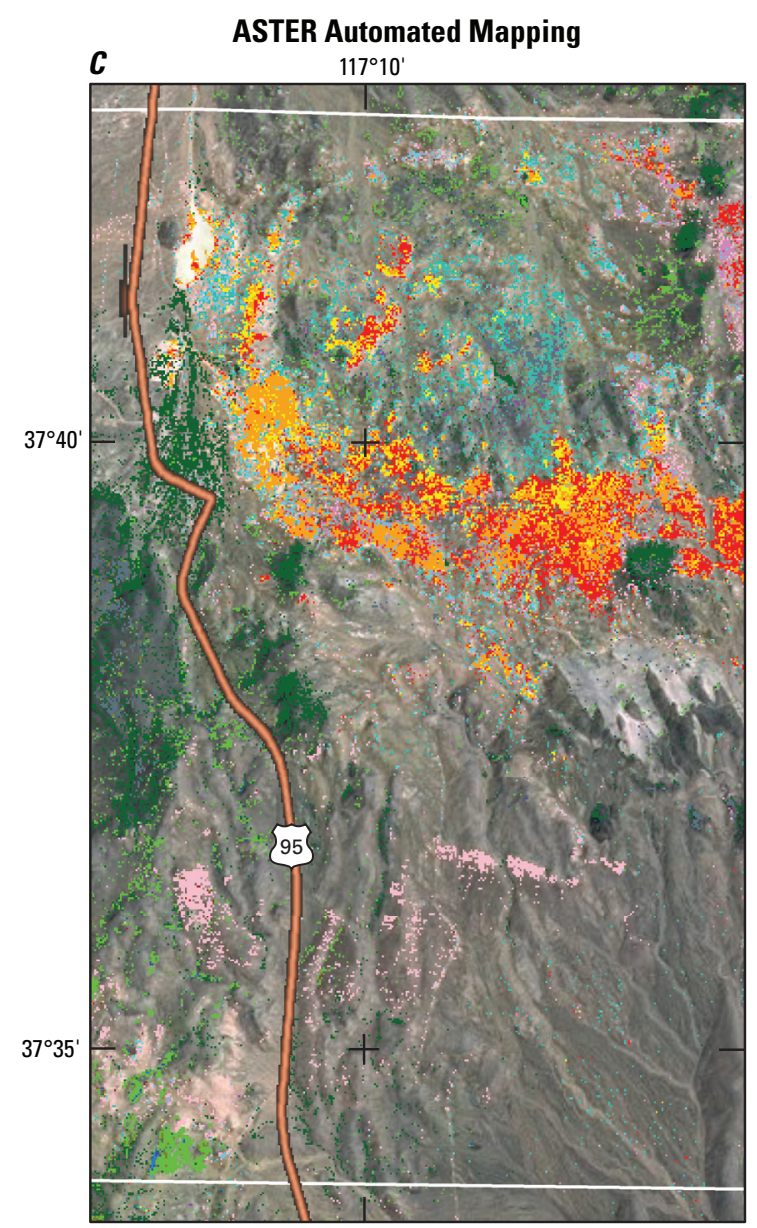

EXPLANATION C

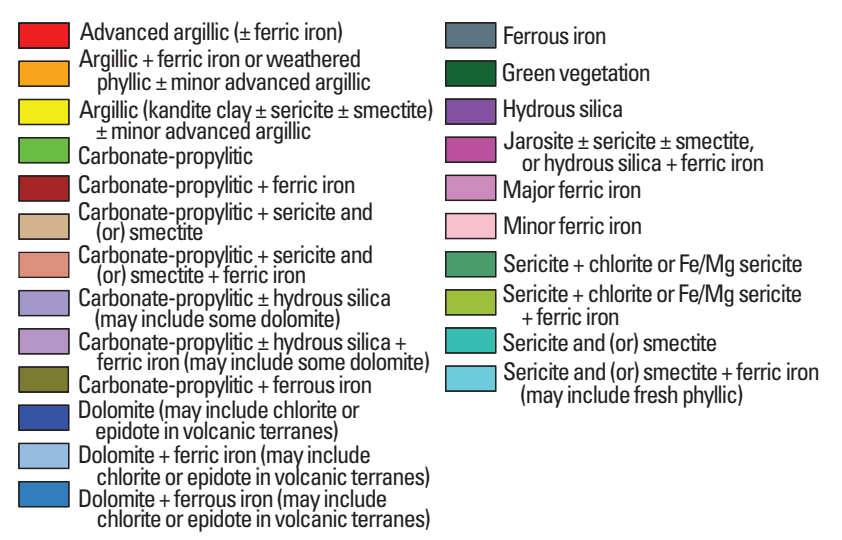


Figure 12 (previous page). Mineral maps of the Goldfield mining district, Nevada. A. Map produced using expert system-based spectroscopic analysis (Rockwell and others, 2005; 2006) of highaltitude AVIRIS data acquired on June 18, 1998 (http://aviris.jpl. nasa.gov/ql/98qlook/f980618t01p02_r02.ql.jpg). B. Map produced using expert system-based spectroscopic analysis (Rockwell, 2009) of ASTER data acquired on August 24, 2001. C. Map produced from orthocorrected (AST140TH) data of the same 2001 ASTER scene using the automated, ratio-based analysis. White lines indicate the limits of the AVIRIS data coverage. Click on figure for more detailed image.

\section{Goldfield Mining District, Nevada}

Mineral maps of the Goldfield mining district produced from AVIRIS and ASTER data are compared in figure 12.Abundant advanced argillic alteration minerals identified in bedrock outcrops show excellent correlation between the maps (red colors). Highly abundant quartz + alunite \pm pyrophyllite alteration on Preble Mountain (“A", in fig. 12A), and spectrally pure jarosite ("B" in fig. $12 A$ ), were identified using both data types and analysis techniques. The map produced using the automated methodology has not identified all occurrences of these minerals where they occur in lower abundance within alluvium derived from the alteration zones, as explained above (fig. 8).

The AVIRIS-based mapping identified several pixels of calcite \pm sericite on the western flanks of Diamond (Mountain) at "C," and epidote just west of Black Butte at "D," both in propylitically-altered andesites. This alteration was also identified with the ASTER data using both analysis techniques, although the automated technique identified it over a wider area (green).

Weakly propylitized, compact quartz latite tuffs and lapilli tuffs near the center of the district at "E" contain illite and chlorite (verified by X-ray diffraction) and were identified as low-aluminum (iron- or magnesium-rich) sericite or muscovite + chlorite mixture by the expert system analysis using both AVIRIS and ASTER data (see description of this mineral mixture in comments for sheet 3 above). The automated analysis mapped these rocks as sericite and (or) smectite surrounded by (and occurring with) ferrous iron, which is indicative of chlorite.
Scattered pixels of hydrous silica were identified across this area with the ASTER data using both analysis techniques. These occurrences have not been field verified, although hydrous silica (opal or chalcedony) within the Siebert Tuff and other rhyolitic airfall tuffs, tuff breccias, and agglutinate (Albers and Stewart, 1972) was identified using both ASTER data analysis techniques in the surrounding area (fig. 13).

The discrimination of limestones and dolomites by the automated analysis is also demonstrated in figure 13. The coarsely-crystalline Precambrian Reed Dolomite on the western slopes of the Montezuma Range is clearly differentiated from the mixed limestone and dolomite of the Precambrian Deep Spring Formation, and from calcite-rich rocks of the Lower Cambrian Mule Spring Limestone to the east. Both ASTER-based analysis techniques identified potentially dolomitic zones within the Mule Spring Limestone. These zones are shown in blue in both maps and likely represent a calcite + dolomite mixture. Ferrous iron was detected in isolated areas within the Mule Spring Limestone, including several of the more dolomitic zones, using the automated analysis.

\section{Cuprite Mining District, Nevada}

Figures 14 and 15 compare AVIRIS- and ASTER-derived mineral maps of a part of the Cuprite mining district located $25 \mathrm{~km}$ south of Goldfield. Late Miocene, advanced argillic alteration in Tertiary rhyolite and latite tuff with intercalated sedimentary rocks (mainly the Siebert Tuff; Abrams and others, 1978; Rowan and others, 2003) is present in two centers bounded on the west by the Lower Cambrian Harkless Formation (dominantly green phyllitic siltstones) and on the south by the Mule Spring Limestone.

The maps in figures 14 and 15 all show the distribution of opaline sinter, alunite-bearing advanced argillic, and kaolinitedominated argillic alteration. Propylitic alteration in the area, although present, is generally weak and poorly exposed with the exception of associated calcite + sericite immediately north and northwest of the western center. The expert systemderived maps show how most alunite zones grade outwards to mixed kaolinite and then sericite-bearing assemblages.

The most recent hypothesis for the genesis of the two centers is that they formed independent of each other and represent two distinct hydrothermal systems (Swayze, 1997). The eastern center is younger and more well-preserved than the western center, which has been eroded more substantially, exposing the fracture-controlled plumbing system of the deposit. More abundant and spectrally pure alunite (and native sulfur deposits) occur along a north-trending, inferred fracture 

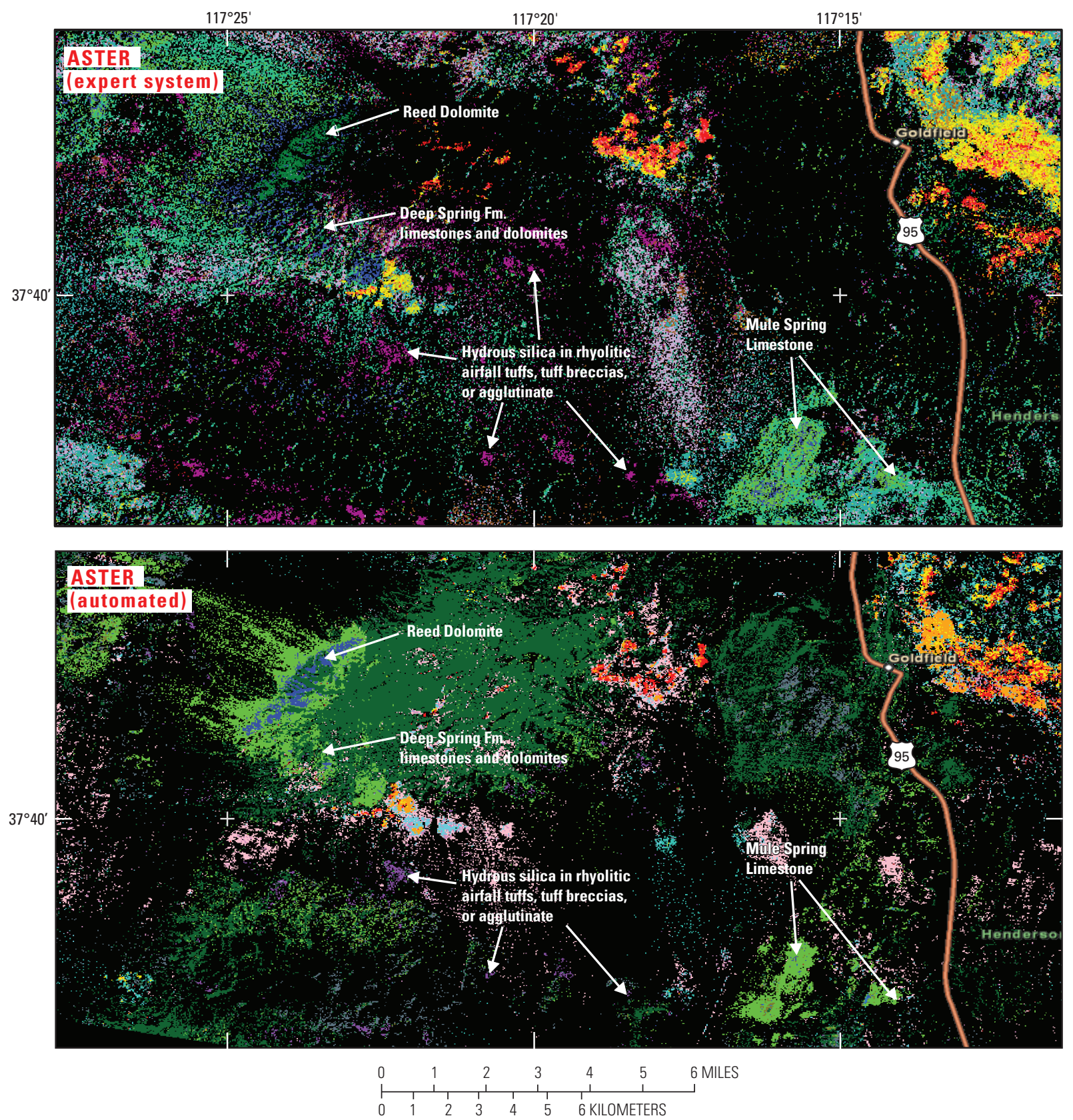

Figure 13. Mineral maps of the Montezuma mining district, Nevada. The town of Goldfield and advanced argillic alteration associated with the Goldfield mining district are visible in the northeastern corners of the maps. The map at top was produced using expert system-based spectroscopic analysis (Rockwell, 2009) of ASTER data acquired on Aug. 4 , 2001. See figure $12 B$ for explanation of color-coded mineral identifications. The map at bottom was produced from orthocorrected (AST140TH) data of the same 2001 ASTER scene using the automated, ratio-based analysis described herein. See figure $12 C$ (and sheet 5 ) for explanation of color-coded mineral identifications. Click on figure for more detailed image. 
Occurance of Iron-Bearing Minerals

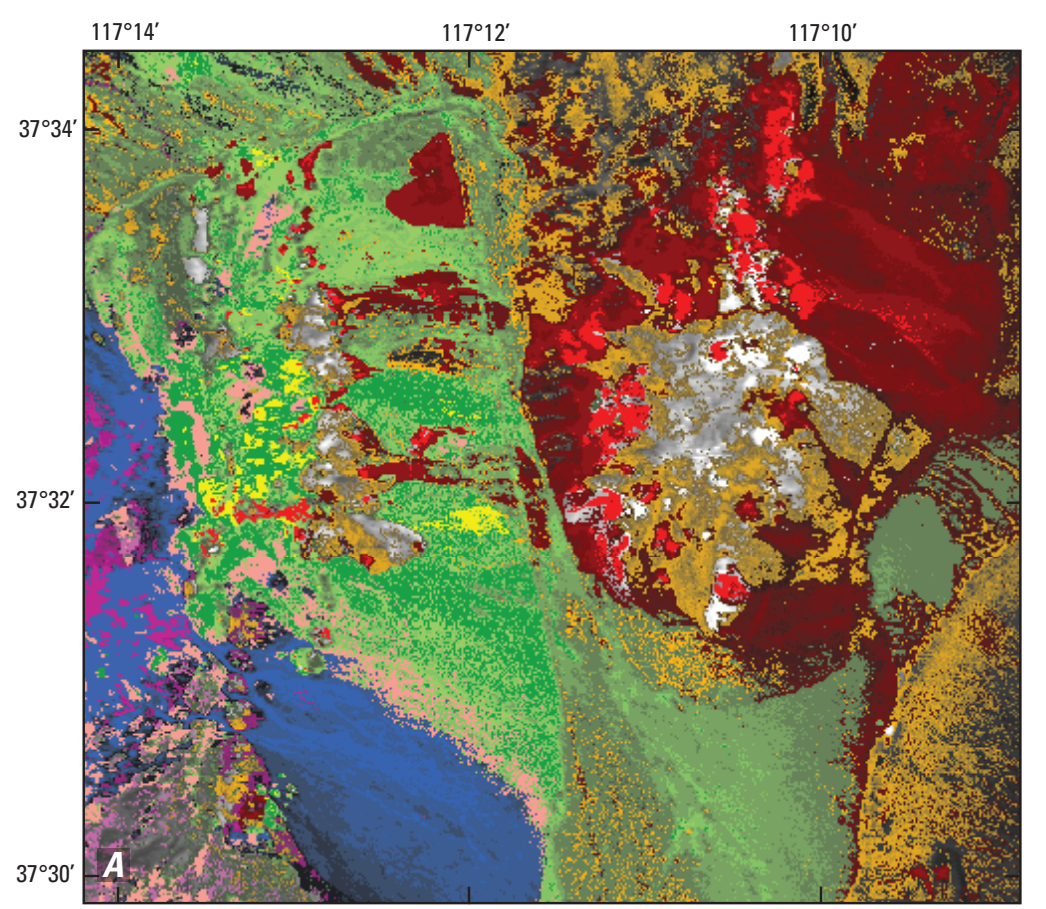

Occurance of Clay, Sulfate, Mica, Carbonate, $\mathrm{Mg}-\mathrm{OH}$, and Hydrous Silica Minerals

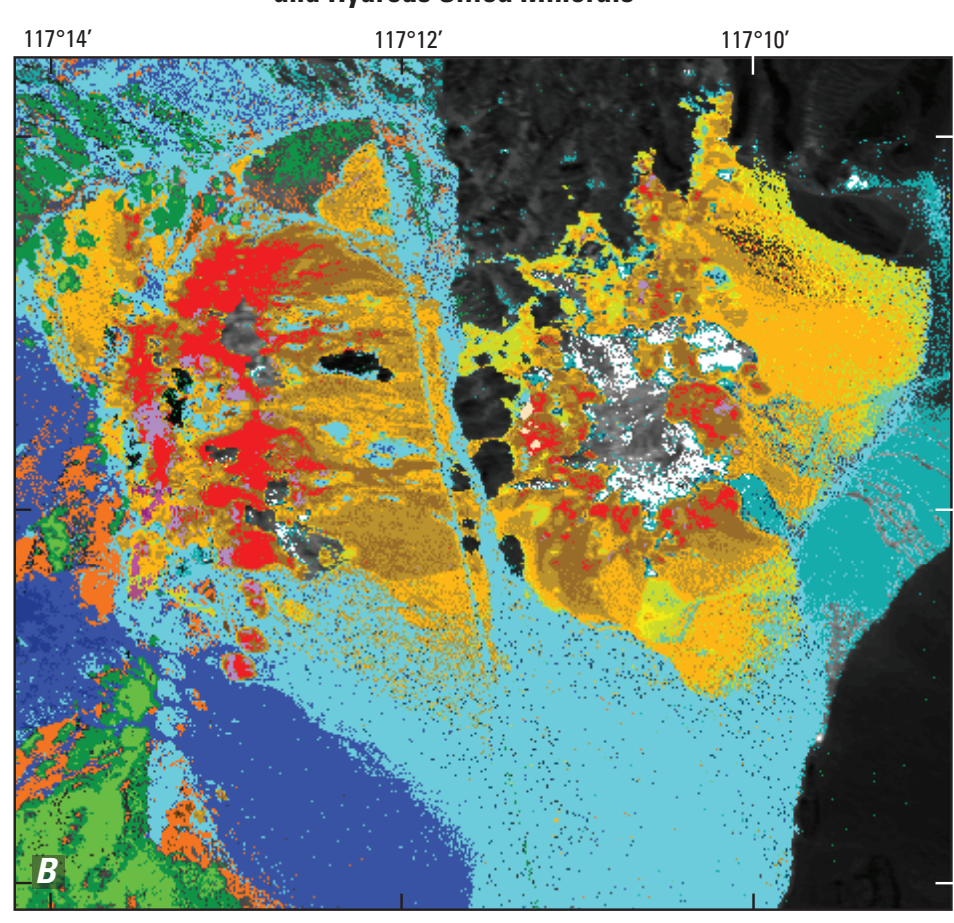

3 MILES

3 KILOMETERS

\begin{tabular}{|c|c|}
\hline \multicolumn{2}{|c|}{$\begin{array}{l}\text { Explanation for high-altitude AVIRIS mapping: } \\
\text { iron-bearing minerals }\end{array}$} \\
\hline $\begin{array}{l}\text { Iron sulfate minerals } \\
\text { Coarse-grained jarosite }\end{array}$ & $\begin{array}{ccc}\text { Iron oxide minerals } \\
\text { C } & \begin{array}{l}\text { Hematite-Fine grained } \\
\text { Hematite-Med. to coarse grained }\end{array}\end{array}$ \\
\hline $\begin{array}{l}\text { Iron Hydroxide Minerals } \\
\text { C Goethite-Thin coating } \\
\text { Goethite-Fine grained } \\
\text { Goethite-Medium grained } \\
\text { Goethite-Coarse grained }\end{array}$ & \begin{tabular}{ll} 
& \multicolumn{1}{c}{$\mathrm{Fe}^{2+}$-bearing Minerals } \\
Generic \\
C & With goethite and sericite \\
\end{tabular} \\
\hline C Other iron oxides and (or) hydroxides & $\begin{array}{l}\text { Chlorite + goethite } \\
\text { C Chlorite + sericite }\end{array}$ \\
\hline
\end{tabular}

C-Continuous stretch applied

\begin{tabular}{|c|c|}
\hline \multicolumn{2}{|c|}{$\begin{array}{l}\text { Explanation for high-altitude AVIRIS mapping: } \\
\text { phyllosilicates, sulfates, carbonates, and silica }\end{array}$} \\
\hline Kaolinite Group Minerals & \multirow{5}{*}{$\begin{array}{l}\text { Sulfate Minerals } \\
\text { Alunite } \\
\text { Alunite-Intermediate Na/K } \\
\text { composition } \\
\text { Natroalunite } \pm \text { dickite, other clays } \\
\text { Katroalunite + kaolinite } \\
\text { K Klunite (K) + kaolinite } \pm \text { illite } \\
\text { Kaolinite } 75 \% \text { + alunite } 25 \% \text { mix } \\
\text { Jarosite }\end{array}$} \\
\hline $\begin{array}{l}\text { Kaolinite (well crystallized) } \\
\text { Kaolinite (poorly crystallized } \\
\text { and (or) mixed float) }\end{array}$ & \\
\hline Kaolinite + sericite & \\
\hline Kaolinite \pm smectite & \\
\hline $\begin{array}{l}\text { Kaolinite } \text { smectite or } \\
\text { halloysite } \\
\text { Dickite }\end{array}$ & \\
\hline \multirow{3}{*}{$\begin{array}{l}\text { Carbonate Minerals } \\
\text { Calcite +sericite } \\
\text { Calcite }\end{array}$} & \multirow{2}{*}{$\begin{array}{l}\text { Ammonium-bearing Minerals } \\
\text { Buddingtonite } \pm \text { montmorillonite }\end{array}$} \\
\hline & \\
\hline & \multirow{3}{*}{$\begin{array}{l}\text { Muscovite Group Minerals } \\
\text { High-Alsericite +chlorite } \\
\text { and lorl calcite } \\
\text { Medium-Al sericite } \\
\text { Low-Al sericite }\end{array}$} \\
\hline \multirow{3}{*}{$\begin{array}{l}\text { Montmorillonite (Ca + Na) } \\
\text { Opal/chalcedony }\end{array}$} & \\
\hline & \\
\hline & Illite + chlorite \\
\hline
\end{tabular}


Figure 14 (previous page). Mineral maps of part of the Cuprite mining district in western Nevada produced using expert systemanalysis (Rockwell and others, 2005; 2006) of high-altitude AVIRIS data acquired on June 18, 1998 (http://aviris.jpl.nasa.gov/ ql/98qlook/f980618t01p02_r02.ql.jpg). A. Map showing occurrence of iron-bearing minerals. $B$. Map showing occurrence of clay, sulfate, mica, carbonate, $\mathrm{Mg}-\mathrm{OH}$, and hydrous silica minerals. Bright shades of color indicate high values of fit $\times$ depth, and successively darker shades indic ate lower values. Fit $\times$ depth is proportional to both the least-squares fit of image spectra to reference laboratory spectra and the depth of the diagnostic absorption feature(s) in the image spectra. Low feature depths may indicate lower abundance of the mineral type in the pixel, given a constant grain size. Click on figure for more detailed image.

system which crosses the western center (magenta arrows in fig. 15). Abundant quartz-alunite also occurs along another, parallel system $\sim 850 \mathrm{~m}$ to the west which forms the highest ridge in the Cuprite Hills. Natroalunite \pm dickite (Rockwell, 2002) generally occurs distal to alunite along these fracture systems, particularly at their southern mapped extent near the periphery of the western center alteration. This occurrence relationship of hypogene alunite and natroalunite has been recognized in the Goldfield district (fig. 12), on East Brawley Peak near the Aurora mining district (Rockwell, 2010a), and on Alunite Ridge in the Tushar Mountains near Marysvale, Utah (Rockwell and others, 2005). The traces of these fracture systems are visible even in the results derived from the automated analysis. Alunite in the eastern center occurs generally beneath and peripheral to the central cap of leached silica, reflecting more replacement-dominated, near-surface solfataric hydrothermal processes of the paleovadose zone.

Most alunites in the district are white to light gray in color, and figure 14 shows that most alunite zones in the district have little to no ferric iron content. Argillic assemblages with minor alunite (including float) surrounding the alunite-rich zones often contain more abundant ferric iron minerals. Alunite of mixed Na-K composition typically has more abundant ferric iron than potassium-rich alunite. In the western center, goethite and jarosite are more abundant than hematite, reflecting the deeper level of erosion which has exposed jarosite derived from subaerial oxidation of pyrite which occurs in underlying phyllically-altered rocks formed in reducing conditions below the paleowater table. Jarosite is particularly abundant in kaolinitic wall rocks surrounding selvages of dickite or kaolinite \pm natroalunite at the southwestern edge of the western center, suggesting pyritization of wall rocks in that area. Some of the jarosite in the western center occurs with alunite, and could represent a hypogene, vadosezone assemblage as has been recognized in steam-heated replacement alunite deposits near Marysvale (Cunningham and others, 1984; Rockwell and others, 2005).

Within the Harkless Formation at left center, the AVIRISbased mapping (fig. 14) identified low- and medium-aluminum sericite (illite), suggesting increased iron and (or) magnesium content relative to aluminum. Large exposures of an illite + chlorite mixture were also identified. Ferrous iron related to the chlorites and (or) illites was mapped throughout the Harkless and locally within the Mule Spring Limestone. Abundant calcite surrounded by calcite + sericite mixtures was mapped in the adjacent Mule Spring Limestone, the latter indicating areal mixtures with sericites from the Harkless Formation and derived alluvium. A calcite-rich area within the Harkless Formation ("C" in fig. 15) was identified by both data types and analysis techniques, and most likely represents either a local limestone member of the Harkless or an erosional remnant of the overlying Mule Spring Limestone that has not been recognized in local geologic mapping (Crafford, 2007).

The Harkless Formation was identified as predominantly sericite and (or) smectite with strong local ferrous iron and "sericite + chlorite or Fe/Mg sericite" by the automated analysis (fig. 15). The expert system-based analysis of ASTER data also identified this Fe/Mg sericite or sericite + chlorite mixture in the Harkless, surrounded by wide exposures of "muscovite \pm calcite or chlorite," representing a spectral match to a reference spectrum of a calcite + muscovite mixture (Rockwell, 2009). Ferrous iron was also identified locally within the calcite of the Mule Spring Limestone.

Exposures of undifferentiated chalcedony and opal were identified in the silica cap of the eastern alteration center using both data types and analysis techniques, although fewer were mapped using the ASTER-based automated technique. This discrepancy is directly related to the relatively high clipping value applied to the hydrous silica-jarosite-sericite index to reduce inaccurate identifications in regional mapping. A small area (one 30-m ASTER pixel) of hydrous silica near the northern edge of alteration in the eastern center which was correctly identified using both data types and analysis techniques is indicated in figure 15 ("HS").

An altered Tertiary rhyolite dike extends south from the dickite-bearing southwestern edge of the western alteration center along the contact between the Harkless Formation and Mule Springs Limestone (fig. 15). The dike contains sericite + kaolinite in rather low abundance (fig. 14; Rowan and others, 2003), and the sericite is aluminum rich (as indicated by the position of the Al-OH feature at $2.199 \mu \mathrm{m}$ absorption). The ASTER-derived maps in figure 15 show that the dike was mapped as aluminum sericite with small kaolinitic zones using the expert system analysis and as "sericite and (or) smectite \pm ferric iron" with several pixels of argillic alteration near its northern end by the automated analysis. The low abundance of the argillic minerals in the altered dike make it difficult to discriminate using the automated analysis. 

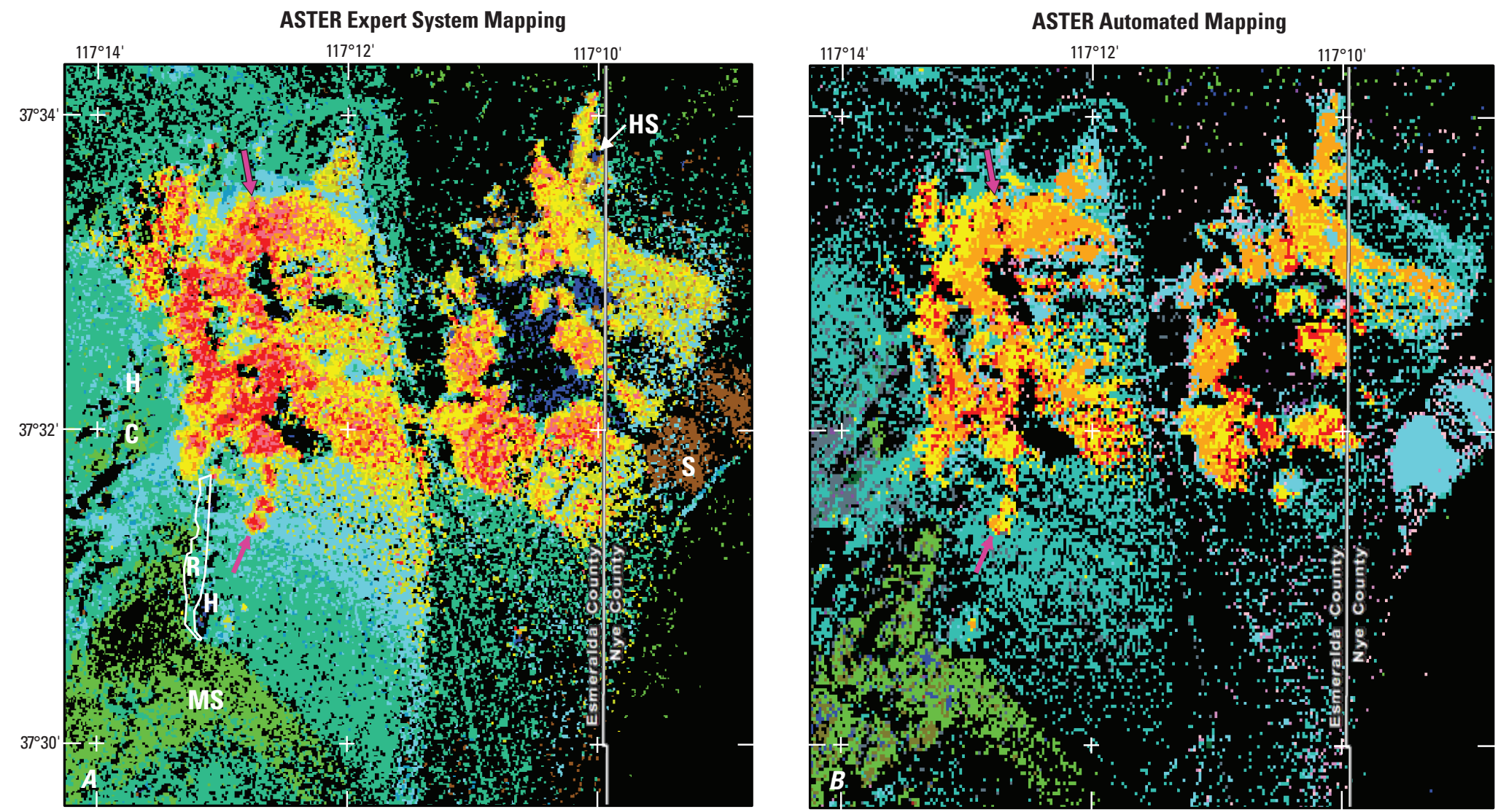

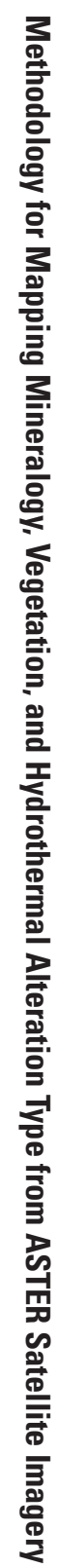
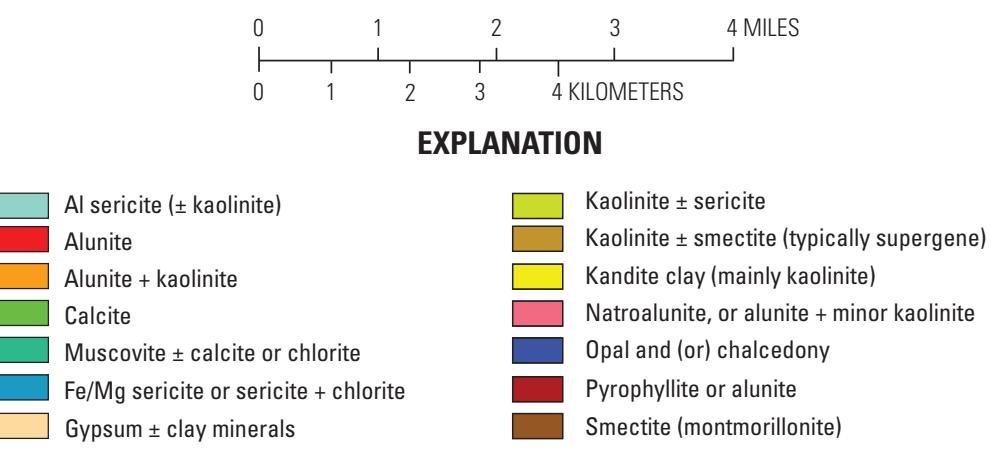
Figure 15 (previous page). ASTER-derived mineral maps of part of the Cuprite mining district, western Nevada. A. Map produced using expert system-based spectroscopic analysis (Rockwell, 2009) of ASTER data acquired August 24, 2001. B. Map produced from the same ASTER scene using the automated ratio-based analysis described herein. See figure $12 C$ (and sheet 5 ) for explanation of color-coded mineral identifications. U.S. Route 95 crosses the center of the maps from south to north between the two alteration centers. Magenta arrows show trace of inferred fracture system along which more abundant and spectrally pure alunite occurs. $\mathrm{H}$, Harkless $\mathrm{Fm}$; $\mathrm{C}$, calcite-rich area within Harkless Fm; MS, Mule Spring Limestone; S, Stonewall Playa; R, Altered rhyolite dike (illite + kaolinite); HS, one of several exposures of hydrous silica identified using AVIRIS data (fig. 14) and both expert system and automated analysis of ASTER data. Click on figure for more detailed image.

\section{Pine Grove and Blawn Mountain Mining Districts, Wah Wah Mountains, Utah}

Mineral maps generated by expert system and automated analysis of ASTER data covering the Wah Wah Mountains in southwestern Utah are compared in figure 16. Explanations of the color-coded mineral identifications in both maps are shown in figure 17.

Both analysis techniques have identified minerals associated with alteration in many areas where alteration had been previously mapped (Ken Krahulec, written commun., Utah Geological Survey, 2010), and in several undocumented areas, including the northwestern San Francisco Mountains (Rockwell and Hofstra, 2009a) and in quartzites surrounding the Pine Grove porphyry molybdenum deposit (Rockwell and Hofstra, 2009b; Rockwell, 2010b). Argillic and advanced argillic alteration in lower abundance in alluvium has not been mapped using the automated techniques because of the clipping of low-end index values, as mentioned above. Especially when dry vegetation with leaf biochemical absorption at ASTER band 5 is present, overdetection of advanced argillic alteration minerals can occur at the expense of kandite clay minerals, such as in the altered rocks surrounding the Pine Grove deposit.

Carbonate minerals in low abundance, including those in alluvium and in formations with silty, impure limestones and interbedded shales (for example, Fillmore and House Formations in the northern part of fig. 16) are also not identified using the automated technique. The spectroscopic analysis of the ASTER data is more sensitive to minerals in low abundance, although the degree to which such exposures are identified using the automated technique is directly related to the clipping values applied to the indices. Such clipping values were optimized for accuracy and completeness over many tested ASTER scenes, but can be adjusted for specific areas as needed.
Detection of dolomite within carbonate units using the automated technique shows good correlation with the expert system analysis results and with mapped dolomitic units (Steven and others, 1990). However, vegetation growing on dolomitic rocks can weaken absorption at ASTER band 7, as can be seen in the Simonson Dolomite just north of the NG Alunite area where most of the dolomite has been identified as "carbonate-propylitic." Therefore, the detection of dolomite within carbonate rocks using the automated technique should not be considered to be comprehensive, and should only serve as a guide to the presence of dolomite within carbonate rocks.

\section{Deficiencies of the Automated Analysis Methodology}

The most serious drawbacks for the use of ASTER-based mineral mapping are related to the data themselves. Although ASTER scenes with minimal cloud cover and optimal solar illumination will be selected for analysis, scenes with unclear atmospheres caused by dust, haze, thin clouds, fog, and smoke will show uncertain results. Suitable ASTER data may not be available for all areas. Spatial misregistration of the ASTER VNIR and SWIR data in some scenes is not currently recognizable during scene selection, and can also cause severe degradation of the results. Crosstalk-related problems in areas adjacent to large bodies of water and other instances of extreme variation in surface albedo will necessitate the use of scenes in which the problems have been corrected, and will thus require additional processing and custom geometric correction. Degraded data associated with the SWIR detector "scratch" create areas of erroneous mapping results in every scene, and necessitate the development of an efficient means of highlighting these areas in large numbers of scenes. In addition, despite logic to reduce the effect of areal mixing of dry vegetation with surface minerals, false detections of argillic and advanced argillic alteration minerals can occur in areas where seasonally dry vegetation such as cheatgrass is present, especially in the northern Great Basin.

The primary problem with a ratio-based spectral analysis algorithm is that there will always be an "answer" to every index. Even if no minerals of a type for which an index was designed to highlight are present in a scene, the high-end values of that index will be shown as a detection result. This effect could be mitigated by the empirical development of quantitative thresholds of index values below which accurate identifications cannot occur. In addition, fuzzy logic could be applied to the index values to model confidence levels of results. However, it would be difficult and time-consuming to develop thresholds that will generate accurate detections over very large regions given the variability of ground cover, atmospheric visibility and moisture content, solar illumination relative to season of data acquisition, and ASTER data quality. Substantial false mineral group detections related to the algorithm itself have not been observed in the testing performed for this study. 


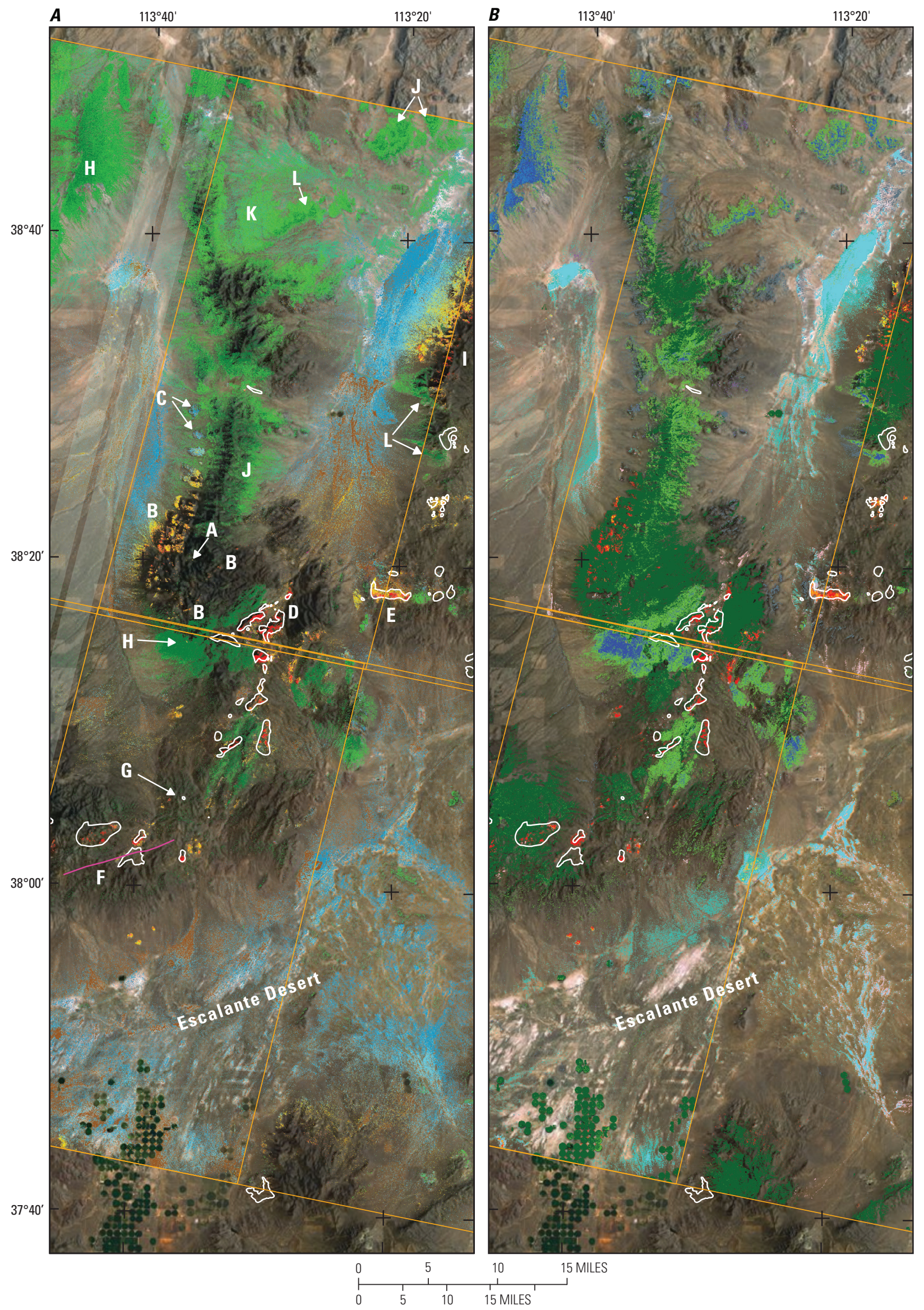


Figure 16 (previous page). ASTER-derived mineral maps of the Wah Wah Mountains, Broken Ridge, and Escalante Desert, southwestern Utah. Orange outlines show extent of four overlapping ASTER scenes from July 31, 2000 (right-hand path) and August 27, 2004 (left-hand path). A. Map produced using expert system-based spectroscopic analysis (Rockwell, 2009) of ASTER data calibrated to reflectance using laboratory spectra of smectite-bearing alluvium from Wah Wah Wash in the central Wah Wah Valley. Areas of 2004 data affected by the SWIR detector "scratch" are indicated by translucent white polygons in the upper left quarter of the map. Kaolinitic assemblages identified in Pine Valley west of the Wah Wah Mountains that occur in the left-hand "scratch" are erroneous in both A and B. B. Map produced from the same ASTER scenes using the automated, ratio-based analysis described herein. See figure 17 for explanation of color-coded mineral identifications. A, Concealed Pine Grove porphyry molybdenum deposit; B, Advanced argillic and argillic alteration (pyrophyllite and dickite with local alunite) associated with the Pine Grove deposit in folded Late Proterozoic and Lower Cambrian quartzites (Rockwell and Hofstra, 2009b); C, Unaltered Prospect Mountain Quartzite (sericite, Lower Cambrian); D, NG Alunite area in Blawn Mountain mining district; E, Alteration associated with Shauntie Hills hydrothermal system; $\mathrm{F}$, Bible Springs fault zone (magenta line) and associated quartzalunite alteration; $G$, rhyolite vent above inferred porphyry molybdenum deposit in Broken Ridge area (Duttweiler and Griffitts, 1989); H, Simonson, Sevy, Laketown, and Fish Haven Dolomites (Ordovician - Devonian); I, Advanced argillic and argillic alteration in Late Proterozoic quartzites (Mutual and Inkom Formations), San Francisco Mountains (Rockwell and Hofstra, 2009a); J, Wah Wah Summit Formation and other Middle and Upper Cambrian limestones and dolomites; K, Fillmore Formation (silty limestone and shales) and House Limestone (Lower Ordovician); L, Notch Peak Formation (interbedded silty limestones and massive dolomite, Lower Ordovician and Upper Cambrian), recrystallized to marble in southern San Francisco Mountains. White polygons show altered areas compiled from a variety of published and unpublished sources (Ken Krahulec, written commun., Utah Geological Survey, 2010). Lithologic units from Steven and others (1990). Click on figure for more detailed image. 
$\boldsymbol{A}$

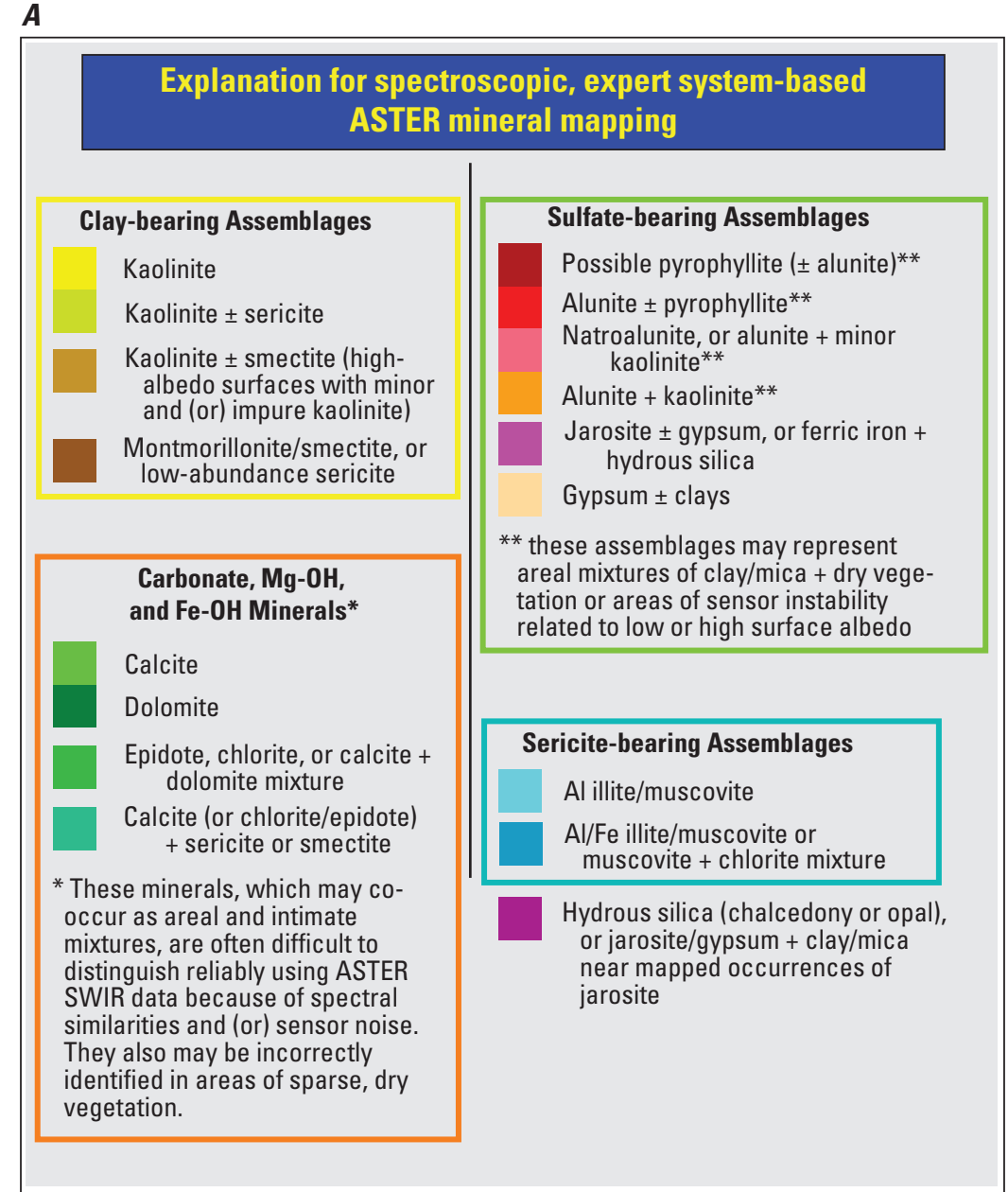

Explanation for Automated ASTER mineral mapping
Attribute name: Materialid
Advanced argillic ( \pm ferric iron)
Argillic and weathered phyllic \pm minor alunite and (or) pyrophyllite
Argillic and weathered phyllic + ferric iron \pm minor alunite and (or) pyrophyllite
Carbonate-propylitic
Carbonate-propylitic + ferric iron
Carbonate-propylitic + sericite
Carbonate-propylitic + sericite + ferric iron
Carbonate-propylitic \pm hydrous silica (may include some dolomite)
Carbonate-propylitic \pm hydrous silica + ferric iron (may include some dolomite)
Carbonate-propylitic + ferrous iron
Dolomite (may include chlorite or epidote in volcanic terranes)
Dolomite + ferrous iron (may include chlorite or epidote in volcanic terranes)
Dolomite + ferric iron (may include chlorite or epidote in volcanic terranes)
Ferrous iron
Green vegetation

Figure 17. Explanations for color-coded mineral and vegetation identifications shown in figure 16. A. Identifications for map in figure $16 A$ made using expert system analysis of ASTER data. $B$. Identifications for map in figure $16 B$ made using automated analysis of ASTER data. Explanation is identical to that of sheet 5 and figure $12 C$. Click on figure for more detailed image. 


\section{Conclusions}

Despite deficiencies in the quality and availability of suitable ASTER data, the products generated by the automated process are suitable for efficient application of mineral resource and geoenvironmental assessments at regional and national scales. Hydrothermal dolomitization of limestone units and subtle argillic alteration in quartzites and quartz arenites, both potentially important indicators of concealed mineral deposits, can be recognized. Potentially acidgenerating altered areas as small as $100 \mathrm{~m}$ in diameter can be identified and characterized as to clay-sulfate-mica-hydrous silica mineralogy. Acid-neutralizing carbonate units and propylitically-altered areas can also be accurately identified.

The more time-intensive spectroscopic analysis of ASTER data can be applied to selected areas and (or) permissive tracts for certain deposit types where more detailed mapping and mineralogical characterization of alteration would be beneficial.

\section{Additional Data}

An ESRI polygon shapefile indicating areas of corrupted ASTER shortwave-infrared data is also provided in a .zip file (sanjuans_aster_scratch_geodrg_shapefile.zip).

\section{Acknowledgments}

The author thanks the U.S. Geological Survey (USGS) Land Processes Distributed Active Archive Center (LP DAAC), the National Aeronautics and Space Administration Earth Observing System Data and Information System (EOSDIS), and Japan's Earth Remote Sensing Data Analysis Center (ERSDAC) for providing the ASTER data that were the foundation of this research. The author also thanks Robert R. McDougal and Douglas B. Yager of the USGS for their helpful reviews of the manuscript, maps, and digital data. Gregg A. Swayze of the USGS provided the field spectrum of Stonewall Playa that was used to calibrate the Goldfield and Cuprite AVIRIS data to reflectance.

\section{References}

Abrams, M.J., Ashley, R.P., Rowan, L.C., Goetz, A.F.H., and Kahle, A.B., 1978, Mapping of hydrothermal alteration in the Cuprite mining district, Nevada, using aircraft scanner images for the spectral region 0.46-2.36 $\mu \mathrm{m}$ : Geology, v. 5, p. 713-718.

Albers, J.P. and Stewart, J.H., 1972, Geology and mineral deposits of Esmeralda County, Nevada: Nevada Bureau of Mines and Geology Bulletin 78, $80 \mathrm{p}$.

Bove, D.J., Mast, M.A., Dalton, J.B., Wright, W.G., and Yager, D.B., 2008, Major styles of mineralization and hydrothermal alteration and related solid- and aqueousphase geochemical signatures: in Church, S.E, von Guerard, P., and Finger, S.E., eds., Integrated investigations of environmental effects of historical mining in the Animas River watershed, San Juan County, Colorado: U.S. Geological Survey Professional Paper 1651, p. 161-230.

Bove, D.J., Yager, D.B., Mast, M.A., and Dalton, J.B., 2007, Alteration map showing major faults and veins and associated water-quality signatures of the Animas River watershed headwaters near Silverton, southwest Colorado: U.S. Geological Survey Scientific Investigations Map 2976, 18 p. pamphlet, 1 pl., scale 1:24,000. Available at http://pubs.usgs.gov/sim/2976/.

Clark, R.N., 1999, Spectroscopy of rocks and minerals and principles of spectroscopy, in Rencz, A.N., ed., Remote sensing for the earth sciences, manual of remote sensing, 3d ed.,part 1, chap. 1, v. 3: New York, John Wiley and Sons, p. 3-58.

Clark, R. N., Gallagher, A.J., and Swayze, G.A., 1990, Material absorption band depth mapping of imaging spectrometer data using the complete band shape least-squares algorithm simultaneously fit to multiple spectral features from multiple materials, in Proceedings of the Third Airborne Visible/Infrared Imaging Spectrometer (AVIRIS) Workshop,Pasadena, Calif., June 4-5, JPL Publication 90-54, p. 176-186.

Clark, R.N., Swayze, G.A., Wise, R.A., Livo, E.K., Hoefen, T.M., Kokaly, R.F., and Sutley, S.J., 2007, USGS digital spectral library splib06a: U.S. Geological Survey Digital Data Series 231. Available at http://speclab.cr.usgs.gov/spectral.lib06.

Crafford, A.E.J., 2007, Geologic map of Nevada: U.S. Geological Survey Data Series 249, scale 1:250,000. Available at http://pubs.usgs.gov/ds/2007/249/.

Crowley, J.K., Brickey, D.W., and Rowan, L.C., 1989, Airborne imaging spectrometer data of the Ruby Mountains, Montana: Mineral discrimination using relative absorption band-depth images: Remote Sensing of Environment, v. 29, p. 121-134. 
Cunningham, C.G., Rye, R.O., Rockwell, B.W., Kunk, M.J., and Councell, T.B., 2005, Supergene destruction of a hydrothermal replacement alunite deposit at Big Rock Candy Mountain, Utah-Mineralogy, spectroscopic remote sensing, stable isotope and argon age evidences: Chemical Geology, v. 215, issues 1-4, p. 317-337. Available at http://dx.doi.org/10.1016/j.chemgeo.2004.06.055.

Cunningham, C.G., Rye, R.O., Steven, T.A., and Mehnert, H.H., 1984, Origins and exploration significance of replacement and vein-type alunite deposits in the Marysvale volcanic field, west central Utah: Economic Geology and the Bulletin of the Society of Economic Geologists, v. 79 , p. $50-71$.

Dalton, J.B., Bove, D.J., and Mladinich, C.S., 2004, Remote Sensing Characterization of the Animas River Watershed, Southwestern Colorado, by AVIRIS Imaging Spectroscopy: U.S. Geological Survey Scientific Investigations Report 2004-5203, 54 p. Available at http://pubs.usgs.gov/ sir/2004/5203/.

Dalton, J.B., Bove, D.J., Mladinich, C.S., and Rockwell, B.W., 2007, Imaging Spectroscopy Applied to the Animas River Watershed and Silverton Caldera, in Church, S.E., von Guerard, P., and Finger, S.E., eds., Integrated Investigations of Environmental Effects of Historical Mining in the Animas River Watershed, San Juan County, Colorado, U.S. Geological Survey Professional Paper 1651, p. 143-159. Available at http://pubs.usgs.gov/pp/1651/downloads/Vol1_ combinedChapters/vol1_chapE2.pdf.

Duttweiler, K.A. and Griffitts, W.R., 1989, Geology and geochemistry of the Broken Ridge area, southern Wah Wah Mountains, Iron County, Utah: U. S. Geological Survey Bulletin 1843, 32 p., 1 pl.

Harsanyi, J.C., and Chang, Chein-I, 1994, Hyperspectral image classification and dimensionality reduction-An orthogonal subspace projection approach: IEEE Transactions on Geoscience and Remote Sensing, v. 32, p. 770-785.

Iwasaki, A., and Tonooka, H., 2005, Validation of a crosstalk correction algorithm for ASTER/SWIR: IEEE Transactions in Geoscience and Remote Sensing, v. 43, no. 12, p. 2747-2751.

Jambor, J.L., Dutrizac, J.E., Groat, L.A., and Raudsepp, Mati., 2002, Static tests of neutralization potentials of silicate and aluminosilicate minerals: Environmental Geology, v. 43, p. 1-17, doi:10.1007/s00254-002-0615-y.

John, D.A., Rockwell, B.W., Henry, C.D., Colgan, J.P., 2010, Hydrothermal alteration of the late Eocene Caetano ashflow caldera, north-central Nevada-A field and ASTER remote sensing study, in Geological Society of Nevada Symposium, Great Basin evolution and metallogeny, Reno, Nev., May 14-22, 2010: Geological Society of Nevada 2010 Symposium Volume, p. 1055-1083.
Jones, S., Herrmann, W., and Gemmell, J.B., 2005, Short wavelength infrared spectral characteristics of the HW horizon-Implications for exploration in the Myra Falls volcanic-hosted massive sulfide camp, Vancouver Island, British Columbia, Canada: Economic Geology and the Bulletin of the Society of Economic Geologists, v. 100, no. 2, p.273-294.

Mars, J.C., and Rowan, L.C., 2006, Regional mapping of phyllic- and argillic-altered rocks in the Zagros magmatic arc, Iran, using Advanced Spaceborne Thermal Emission and Reflection Radiometer (ASTER) data and logical operator algorithms: Geosphere, v. 2, p. 161-186, doi:10.1130/GES00044.1.

Rockwell, B.W., 2002, Descriptions, spectral plots, and digital spectra of samples applied to spectral analysis of imaging spectroscopy data-Utah (East Tintic Mountains, Oquirrh Mountains, Wasatch Mountains, and Tushar Mountains), Nevada (Goldfield Hills), and New Mexico (Jemez Mountains), U.S.A., 1999-2002: U.S. Geological Survey OpenFile Report 2002-407. Available at http://pubs.usgs.gov/of/2002/ofr-02-407/.

Rockwell, B.W., 2004, Spectral variations in rocks and soils containing ferric iron hydroxide and (or) sulfate minerals as seen by AVIRIS and laboratory spectroscopy: U.S. Geological Survey Open-File Report 2004-1431, 24 p. Available at http://pubs.usgs.gov/of/2004/1431/.

Rockwell, B.W., 2009, Comparison of ASTER- and AVIRISderived mineral and vegetation maps of the White Horse replacement alunite deposit and surrounding area, Marysvale volcanic field, Utah: U.S. Geological Survey Scientific Investigations Report 2009-5117, 31 p. Available at http://pubs.usgs.gov/sir/2009/5117/.

Rockwell, B.W., 2010a, Mineral and vegetation maps of the Bodie Hills, Sweetwater Mountains, and Wassuk Range, California/Nevada, generated from ASTER satellite data: U.S. Geological Survey Scientific Investigations Map 3104, 5 p. pamphlet, 4 pls. scale 1:62,000. Available at http://pubs.usgs.gov/sim/3104/.

Rockwell, B.W., 2010b, Evaluation of detailed and automated methodologies for hydrothermal alteration mapping from space: application to geoenvironmental and mineral resource assessments at the scale of watersheds and permissive tracts [abs. and PowerPoint presentation]: Geological Society of America Abstracts with Programs, Annual Meeting, Oct. 31-Nov. 3, 2010, Denver, Colo., http://gsa.confex. com/gsa/2010AM/finalprogram/abstract_179892.htm.

Rockwell, B.W., Cunningham, C.G., Breit, G.N., and Rye, R.O., 2006, Spectroscopic Mapping of the White Horse Alunite Deposit, Marysvale Volcanic Field, Utah-Evidence of a Magmatic Component: Economic Geology and the Bulletin of the Society of Economic Geologists, v. 101, no. 7, p. 1377-1395. 
Rockwell, B.W. and Hofstra, A.H., 2008, Identification of quartz and carbonate minerals across northern Nevada using ASTER thermal infrared emissivity data-Implications for geologic mapping and mineral resource investigations in well-studied and frontier areas: Geosphere, v. 4, no. 1, p. 218-246, doi: 10.1130/GES00126.1.

Rockwell, B.W. and Hofstra, A.H., 2009a, Mapping argillic and advanced argillic alteration in volcanic rocks, quartzites, and quartz arenites in the western Richfield $1^{\circ} \times 2^{\circ}$ quadrangle, southwestern Utah, using ASTER satellite data [abs.], in Geological Society of America Abstracts with Programs, Rocky Mountain Sectional Meeting, Orem, Utah, May 11-13, 2009, v. 41, no. 6, p. 39. Available at http://gsa. confex.com/gsa/2009RM/finalprogram/abstract_157802.htm.

Rockwell, B.W. and Hofstra, A.H., 2009b, Remote detection of argillic alteration in quartzites and quartz arenites above and distal to porphyry $\mathrm{Cu}$ and $\mathrm{Mo}$ deposits-Implications for assessments of concealed deposits [abs.], in Geological Society of America Abstracts with Programs, Rocky Mountain Sectional Meeting, Orem, Utah, May 11-13, 2009 , v. 41, no. 6, p. 6. Available at http://gsa.confex.com/ gsa/2009RM/finalprogram/abstract_157797.htm.

Rockwell, B.W., McDougal, R.R., and Gent, C.A., 2005, Remote Sensing for Environmental Site Screening and Watershed Evaluation in Utah Mine Lands-East Tintic Mountains, Oquirrh Mountains, and Tushar Mountains: U.S. Geological Survey Scientific Investigations Report 2004-5241, 84 p. Available at http://pubs.usgs.gov/sir/2004/5241/. A full HTML-format version of the report is available at $h t t p: / / s p e c l a b . c r . u s g s$. gov/earth.studies/Utah-1/sir5241txto_bredit.html.

Rowan, L.C., Hook, S.J., Abrams, M.J., and Mars, J.C., 2003, Mapping hydrothermally altered rocks at Cuprite, Nevada, using the Advanced Spaceborne Thermal Emission and Reflection Radiometer (ASTER), a new satellite-imaging system: Economic Geology and the Bulletin of the Society of Economic Geologists, v. 98, no. 5, p. 1019-1027.

Rowan, L.C., and Mars, J.C., 2003, Lithologic mapping in the Mountain Pass, California area using Advanced Spaceborne Thermal Emission and Reflection Radiometer (ASTER) data: Remote Sensing of Environment, v. 84, no. 3, p. 350-366.

Steven, T.A., Morris, H.T., and Rowley, P.O., 1990, Geologic map of the Richfield $1^{\circ} \times 2^{\circ}$ quadrangles, west-central Utah: U. S. Geological Survey Miscellaneous Investigations Series 1-1901, 1 sheet, scale 1:250,000.

Swayze, G.A., 1997, The hydrothermal and structural history of the Cuprite mining district, Southwestern Nevada-An integrated geological and geophysical approach: Boulder, Colo., University of Colorado, Ph.D. dissertation, 399 p.
Yager, D.B., Choate, L., and Stanton, M.R., 2008, Net acid production, acid neutralizing capacity, and associated mineralogical and geochemical characteristics of Animas River watershed igneous rocks near Silverton, Colorado: U. S. Geological Survey Scientific Investigations Report 20085063, 63 p. Available at http://pubs.usgs.gov/sir/2008/5063/.

Yager, D.B., McCafferty, A.E., Stanton, M.R., Diehl, S.F., Driscoll, R.L., Fey, D.L. and Sutley, S.J., 2005, Net acid production, acid neutralizing capacity, and associated geophysical, mineralogical, and geochemical characteristics of Animas River watershed rocks near Silverton, Colorado: U. S. Geological Survey Open-File Report 2005-1433, 75 p., 1 sheet. Available at http://pubs.usgs.gov/of/2005/1433/.
Publishing support provided by:

Denver Publishing Service Center

For more information concerning this publication, contact:

Center Director, USGS Central Mineral and Environmental Resources Science Center

Box 25046, Mail Stop 973

Denver, CO 80225

(303) 236-1562

Or visit the Central Mineral Resources Team Web site at: http://minerals.cr.usgs.gov/ 


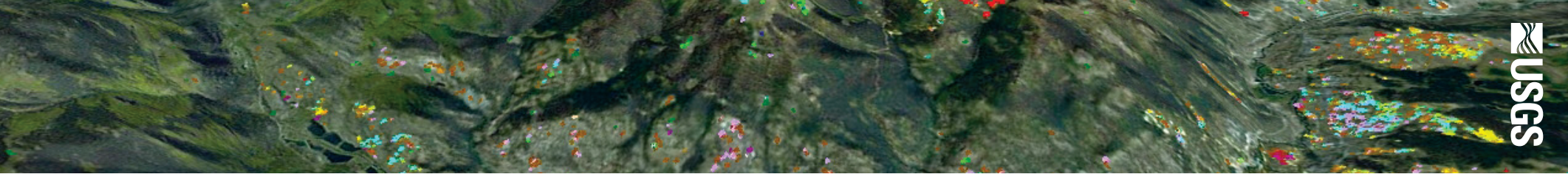

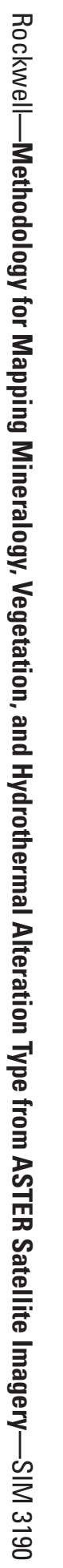

